\title{
Aspect influence on productivity when applying the deferment harvest method in mixed-oak hardwood forests in West Virginia
}

\author{
Breanne Held \\ blh0027@mix.wvu.edu
}

Follow this and additional works at: https://researchrepository.wvu.edu/etd

Part of the Forest Management Commons

\section{Recommended Citation}

Held, Breanne, "Aspect influence on productivity when applying the deferment harvest method in mixedoak hardwood forests in West Virginia" (2019). Graduate Theses, Dissertations, and Problem Reports. 4104.

https://researchrepository.wvu.edu/etd/4104

This Thesis is protected by copyright and/or related rights. It has been brought to you by the The Research Repository @ WVU with permission from the rights-holder(s). You are free to use this Thesis in any way that is permitted by the copyright and related rights legislation that applies to your use. For other uses you must obtain permission from the rights-holder(s) directly, unless additional rights are indicated by a Creative Commons license in the record and/ or on the work itself. This Thesis has been accepted for inclusion in WVU Graduate Theses, Dissertations, and Problem Reports collection by an authorized administrator of The Research Repository @ WVU. For more information, please contact researchrepository@mail.wvu.edu. 
Aspect influence on productivity when applying the deferment harvest method in mixedoak hardwood forests in West Virginia

Breanne L. Held

Thesis submitted

to the Davis College of Agriculture, Natural Resources, and Design

at West Virginia University

in partial fulfillment of the requirements for the degree of

Master of Science in

Forestry

Jamie Schuler, Ph.D., Chair

Melissa Thomas-Van Gundy, Ph.D

David McGill, Ph.D.

Division of Forestry and Natural Resources

Morgantown, West Virginia

2019

Keywords: forest management, deferment, central

Appalachian, aspect, oak

Copyright 2019 Breanne Held 


\title{
ABSTRACT \\ Aspect influence on productivity when applying the deferment harvest method in mixed- oak hardwood forests in West Virginia
}

\author{
Breanne L. Held
}

The deferment harvest method is a new forest management treatment in central Appalachian hardwood forests. It is intended to primarily improve aesthetics by leaving select residual trees in the forest stand beyond the establishment of the regeneration cohort. However, there are concerns with residual tree quality due to the development of epicormic branches and if the presence of forest canopy influences the species composition and development of the regeneration. Topographic aspect can influence differences in productivity in both the residual and regeneration cohorts. This study examined if residual tree quality for timber value and a desirable species composition of the regeneration cohort differed by aspect (i.e., south and east). Epicormic branches were present on majority of the residual trees but did not reduce the quality nor the presumed lumber value of these trees. Forest canopy had no effect on the species composition and development of the regeneration cohort, while there were differences between the south and east aspects in species diversity and stem density of the mid-tolerant species. The regeneration cohort was dominated primarily by commercial species with both shade-intolerant and shade-tolerant species present. These results suggested that maintaining timber value of residual trees and regenerating commercial tree species is possible with the deferment harvest method. 


\section{TABLE OF CONTENTS}

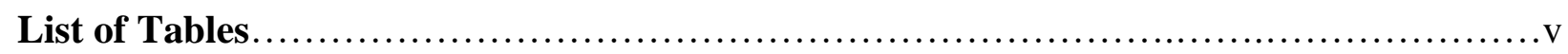

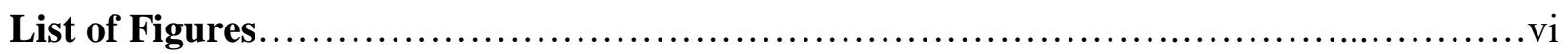

List of Appendices.................................................................. vii

\section{Introduction}

Introduction to the Deferment Harvest Method..............................................1

Current Knowledge About Deferment Harvesting.....................................

Application of the Deferment Harvest Method ........................................5

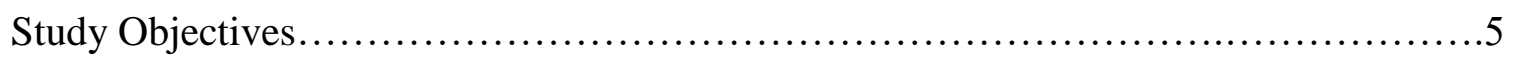

\section{Literature Review}

Part I: Forest Management in Central Appalachian Hardwood Forests...................6

Part II: Deferment Harvest Method in Central Appalachian Hardwood Forests............10

Part III: Factors Influencing the Residual Trees in Deferment Stands...................11

Part IV: Factors Influencing the Regeneration Cohort in Deferment Stands..............12

Part V: How Aspect Influences Forest Productivity..................................13

\section{Materials and Methods}

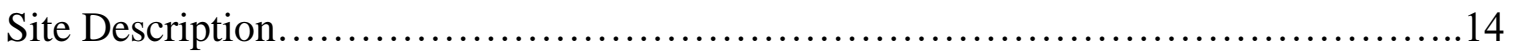

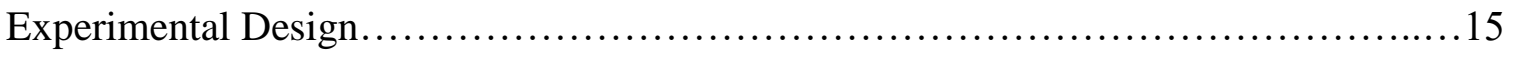

Field Methods................................................................... 16

Residual Cohort...................................................... 17

Regeneration Cohort.................................................... 18

Canopy Cover Analysis................................................... 18

Data Analysis.................................................................. 19

Effect of Epicormic Branches on Tree Quality and Species.....................19

Effect of Epicormic Branches on Timber Value.............................20

Canopy Cover Influence on Regeneration Cohort...........................22 


\section{Results}

Epicormic Branch Impact on Residual Tree Quality................................24

Residual Cohort Inventory............................................. 24

Effect of Epicormic Branches on Tree Quality and Species.....................25

Differences in Timber Value by Aspect..................................26

Effect of Epicormic Branches on Timber Value............................28

Canopy Cover Influence on Regeneration Cohort................................... 30

Regeneration Cohort Inventory...................................... 30

Effect of Canopy Cover and Aspect on the Species Composition.................30

Effect of Canopy Cover on Dominant Height ................................... 32

\section{Discussion}

Effect of Epicormic Branches on Tree Quality...................................33

Effect of Epicormic Branches on Timber Value..................................... 36

Effect of Canopy Cover on the Regeneration Cohort.................................36

Conclusions..................................................................... 39

Acknowledgements........................................................ 40

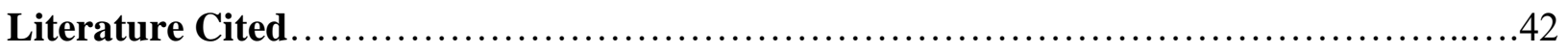

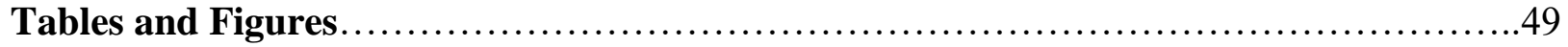

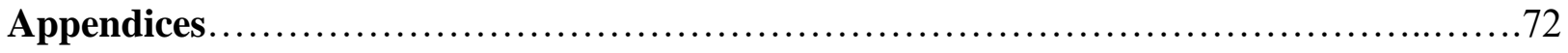




\section{LIST OF TABLES}

Table 1. Number of residual trees of each species with epicormic branches. Species abundance is described in total trees and trees with epicormic branches present....

Table 2. Number of residual trees with epicormic branches for each tree grade. Species abundance is described in total trees and trees with epicormic branches present.....

Table 3. Present lumber value per acre of each species on each aspect in $2018 \ldots \ldots \ldots \ldots \ldots . . . .50$

Table 4. Number of residual merchantable trees downgraded in tree grade due to the presence of epicormic branches on the south and east aspects

Table 5. Total number of commercial and non-commercial species present in the regeneration cohort four years after deferment harvest.............................................. 51

Table 6. Species richness in each aspect by shade tolerance class........................51

Table 7A. Species of the regeneration cohort by dominant height on the south aspect. Dominant height is written as average \pm standard error..........................................5

Table 7B. Species of the regeneration cohort by dominant height on the east aspect. Dominant height is written as average \pm standard error. 


\section{LIST OF FIGURES}

Figure 1. Diagram of aspect slopes and their corresponding moisture contents. Adapted from Carvell and Perkey (1997).

Figure 2. Map of study site with the ten permanent plots established by the consulting forester. These plots were established immediately after harvest and randomly throughout the site to monitor growth and timber production over time until next intended harvest in 25 years.........55

Figure 3. Map of study site with the nine residual plot points constructed in each aspect replicate. Four of the permanent plots established by the consulting forester were included in the residual plot sample, with two plots in one south replicate and two plots in one east replicate....56

Figure 4. Conceptual layout of experimental design. Nine residual plots were nested within each of the six aspect replicates (three on the south aspect, three on the east aspect), with four regeneration plots nested within each residual plot.

Figure 5. Average square feet basal area per acre of each species in the residual cohort on the A) south and B) east aspects. Error bars represent average \pm standard error. .58

Figure 6. Average board feet per acre of volume of each species in the residual cohort on the A) south and B) east aspects. Error bars represent average \pm standard error.

Figure 7. Number of residual trees with and without epicormic branches on the A) south and B)

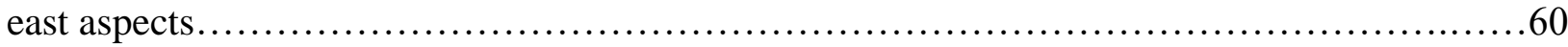

Figure 8. Total volume production (BF) per acre on the south and east aspects over 25 years. Volume is expected to increase as it is dependent on the increase in DBH and merchantable height of each tree over time. Statistical t-test indicated no difference in volume production

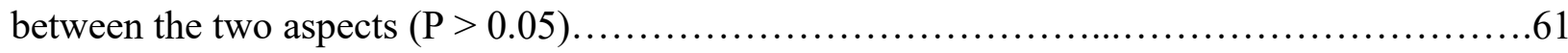

Figure 9. Annual rate of return on the total present value per acre up to 25 years after harvest.

Figure 10. Present lumber value per acre over 25 years at $4 \%, 6 \%$, and $8 \%$ rates of return on the A) south and B) east aspects.

Figure 11. Present lumber value per acre of oak species on the south aspect at A) $4 \%$, B) $6 \%$,

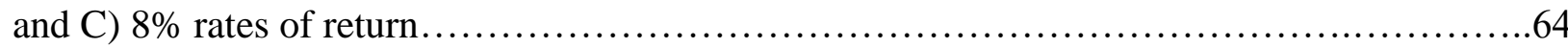

Figure 12. Present lumber value per acre of oak species on the east aspect at A) 4\%, B) 6\%, and

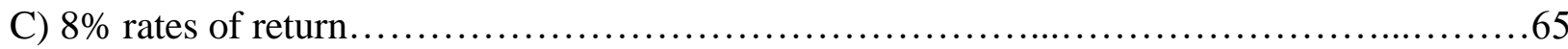


Figure 13. Downgraded and potential present lumber values per acre of each species that were downgraded in quality due to the presence of epicormic branches on the A-B) south aspect and the C-D) east aspect. Downgraded values are the values of each species in their condition at time of inventory in 2018 with the effect of epicormic branches (A \& C). The potential values are the values if trees of these species were not affected by epicormic branches (B \& D). Projections are the present lumber values at $4 \%$ rate of return over 25 years...............................66

Figure 14. Species distribution in average stems per acre of regeneration stems at least 0.5 feet tall and less than one inch DBH on A) south and B) east aspects. Error bars represent average \pm

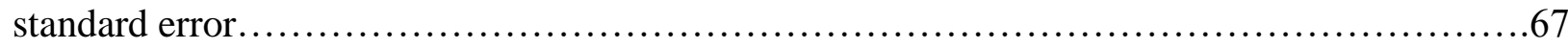

Figure 15. Species diversity as a function of canopy cover from the residual cohort of A) total regeneration species and B) only the commercial species. Original values are displayed here, while analysis required the use of cube transformation values for species diversity....

Figure 16. Average stems per acre on the south and east aspects by shade tolerance class for both A) total and B) commercial species. Error bars represent average \pm standard error. Bars for each shade tolerance group with the same letter are not significantly different $(P>0.05)$.

Figure 17. Stem density as a function of canopy cover from the residual cohort of total regeneration species (A-C) and only the commercial species (D-F) on the south and east aspects. Original values are displayed here for all three shade tolerance groups, while analysis required the use of $\log$ transformation values for only shade-intolerant and mid-tolerant groups...........70

Figure 18. Dominant height of the regeneration stems as a function of canopy cover from the residual cohort of $\mathrm{A}$ ) total regeneration species and $\mathrm{B}$ ) only the commercial species 


\section{LIST OF APPENDICES}

Appendix A. Lumber prices of each species at each projected year. These prices were factored into calculating the present value of each species. Values adapted from the Hardwood Market Report for each projected year (2019-2039) (Johnson et al., 2018) ............................72

Appendix B. Expected lumber yield (percent, \%, of tree scale by lumber quality) determined for calculating the delivered log value for the lumber. Each table is sorted by tree grade and lumber quality for each species (hickory, northern red oak, red maple, sugar maple, white oak, yellow-poplar. Adapted from West Virginia University Appalachian Hardwood Center. ...

Appendix C. The following is a list of the species in the regeneration cohort by shade tolerance group. The species composition included total of 32 species, with 15 of them classified as commercial. Shade tolerance was classified using descriptions from Burns and Honkala (1990). 


\section{INTRODUCTION}

\section{Introduction to the Deferment Harvest Method}

In many areas of the eastern United States, clearcut harvests were implemented to restore the species composition of eastern deciduous forests after decades of partial harvest practices throughout the Appalachian region (i.e., diameter-limit cutting) (Smith, 1981; Nyland, 2005; Vickers and Fox, 2015; Schuler et al. 2017). These previous harvest practices favored more shade-tolerant species, such as red maple (Acer rubrum) (Marquis, 1967; Vickers and Fox, 2015; Schuler et al. 2017; Greenler and Saunders, 2019), and displaced other desirable, shadeintolerant species, such as yellow-poplar (Liriodendron tulipfera) and northern red oak (Quercus rubra) (Schuler and Miller, 1995; Brose et al., 1999; Greenler and Saunders, 2019). This loss of shade-intolerant species reduces the species diversity (Miller and Smith, 1991; Schuler, 2004; Schuler et al., 2017). Clearcut harvests can result in fully stocked stands of highly valuable species for timber resources and restore or sustain the species diversity of the deciduous forest (Smith, 1981; Dale et al., 1995; Miller and Schuler, 1995; Miller et al., 1995; Miller et al., 1997a; Brashears et al., 2004; Miller et al., 2006; Vickers and Fox, 2015). Successful establishment of these fully stocked stands and restoration of the species composition requires some type of disturbance (Schuler et al., 2017), and a clearcut harvest is capable of establishing such disturbance. Clearcut harvests also provide lower harvest costs by harvesting all the trees in one harvest operation (Marquis, 1967; Miller et al., 2004; Miller et al., 2006).

Although clearcut harvests provide these economic and environmental benefits, there remains much public opposition and criticism towards the appearance of young clearcut stands (Smith, 1981; Smith and Miller, 1991; Miller et al., 1995; Miller et al., 1997b; Johnson et al., 1998; Ribe, 2005; Palmer, 2008). The public's expectations of a forest usually include the 
presence of numerous large trees and wildlife (Magill, 1992; Ribe, 2005). These elements create positive attitudes and emotions from these experiences of being in the forest (Ribe, 2005; Newsome et al. 2010). In response to widespread opposition to clearcutting, forest managers and scientists sought to implement alternative management options that would address public expectations, while continuing to meet necessary forest management objectives (Miller et al., 1995; Miller et al., 1997b; Johnson et al., 1998; Wurtz and Zasada, 2001; Miller et al., 2004; Miller et al., 2006; Thomas-Van Gundy and Schuler, 2008; Newsome et al., 2010).

The deferment harvest method was introduced to the central Appalachian region primarily to improve the aesthetics of forests following management operations. In contrast to clearcutting, this management method strives to meet the public expectation of leaving select residual trees to maintain the vertical structure and forest-like appearance (Smith et al., 1989; Magill, 1992; Miller and Schuler, 1995; Miller et al., 1995; Miller, 1996; Miller et al., 1997a; Miller et al., 1997b; Johnson et al., 1998; Ribe, 2005; Palmer, 2008; Thomas-Van Gundy and Schuler, 2008). This new silvicultural practice results in two distinct age classes: an older cohort of select residual trees with a younger regeneration cohort (Smith and Miller, 1991; Miller and Schuler, 1995; Miller et al., 1997a; Johnson et al., 1998; Thomas-Van Gundy and Schuler, 2008; Brown et al., 2018). The select residual trees are intended to remain in the forest stand until the next scheduled harvest, which occurs once the regeneration is at least 40 and up to 80 years of age (Smith et al., 1989; Miller and Schuler, 1995; Miller et al., 1995; Miller, 1996; Miller et al., 1997a; Miller et al., 1997b; Johnson et al., 1998; Miller et al., 2004; Miller et al., 2006; ThomasVan Gundy and Schuler, 2008; Brown et al., 2018).

In addition to improving the aesthetics of the post-harvest stand, the deferment method provides other benefits in meeting forest management objectives. One outcome is the provision 
of suitable habitat for wildlife (Miller et al., 1995; Miller, 1996; Miller et al., 1997b). Another outcome is providing variable light conditions and stand structure, which aid in regenerating both shade-intolerant and shade-tolerant hardwood species, thereby contributing to high-quality timber production (Smith et al., 1989; Miller and Schuler, 1995; Miller, 1996; Miller et al., 1997a; Johnson et al., 1998; Thomas-Van Gundy and Schuler, 2008).

\section{Current Knowledge About Deferment Harvesting}

The first research and implementation of the deferment harvest method took place on public lands in the central Appalachian region. Most of these studies were executed at the Fernow Experimental Forest and the Monongahela National Forest in West Virginia. Researchers evaluated the effect of epicormic branches on tree quality of the residual trees (Smith et al., 1989; Miller, 1996; Miller et al., 1997a), overall development and species composition of the regeneration cohort (Smith et al., 1989; Miller and Schuler, 1995; Miller et al., 1997a; Thomas-Van Gundy and Schuler, 2008), contributions to seed bank and stem origin of regeneration development (Smith et al., 1989), and the influence of overstory canopy on the development of the regeneration (Miller et al., 2004; Miller et al., 2006).

The production of high quality timber is often a priority for management of eastern hardwood forests. The select residual trees left after deferment should be those with the potential to improve their quality (i.e., increase in grade and lumber value). However, one drawback from conducting a deferment harvest is the greater potential for residual trees to develop epicormic branches. This study was initiated to assess the extent of epicormic branch development and its effect on overall stem quality of the residual trees following a deferment harvest. These branches are the greatest cause of reduced tree quality due to the formation of knots and defects (Johnson 
et al., 1998). A tree reduced in quality due to epicormic branches eventually leads to reduced lumber value (Miller, 1996; Meadows and Burkhardt, 2001; Gordon et al., 2006; Ishii et al., 2007; O’Hara and Berrill, 2009; Meier et al., 2012; Meadows et al., 2013). Previous studies in West Virginia indicated the development of epicormic branches to become a major concern on the sawtimber logs of residual trees (Miller, 1996). However, only a small portion $(<10 \%)$ of the residual trees had enough epicormic branches to lower overall quality (Smith et al., 1989; Miller et al., 1997a). It remains unknown whether a small impact of the epicormic branches extends to a significant loss in timber value.

This study was also initiated to assess the influence of deferment cutting on the species composition and development of the regeneration cohort due to the presence of canopy from the residual trees. The canopy of the residual trees can modify the environmental conditions, which is dependent on the amount of residual trees that remain in the stand after harvest. For example, the amount of light penetrating to the forest floor can vary based on the amount of residual basal area retained from harvest (Collet et al., 2001). Miller et al. (2004, 2006) were the first studies to observe the effect of residual tree canopy on the height and species composition of the regeneration 20 years after conducting a deferment harvest in West Virginia. These studies determined how the canopy of the residual trees influenced the diameter and height of the regeneration. There remains uncertainty if the total canopy of the residual trees in a deferment stand can influence the species composition and development of the regeneration early in stand development when the overstory remains for an extended period of time.

Site quality factors (i.e., aspect) influence overall species composition and development of a forest stand after any disturbance. Environmental factors, such as light quantity, moisture content, soil physical and chemical properties, and air temperature vary by aspect (Olivero and 
Hix, 1998; Måren et al. 2015). For example, north and east aspects have greater moisture content, which favors more species adapted to higher moisture environments, such as yellowpoplar. In contrast, south and west aspects have lower moisture content due to greater sunlight exposure, which are more favorable for oak species (Quercus spp.). This study considered differences between contrasting aspects (i.e., south and east) on timber production, and the species composition and development of regeneration following the initial deferment harvest. Previous studies observed differences in growth and the species composition of both the residual and regeneration cohorts to vary between contrasting aspects (Olivero and Hix, 1998; Måren et al. 2015).

\section{Application of the Deferment Harvest Method}

There is a need to extend the knowledge of these observed fundamentals about the deferment harvest method in the central Appalachian region. As stated earlier, most research on deferment harvest has been conducted on stands harvested under controlled conditions on public lands. This current study capitalized on an opportunity to test the application of the deferment harvest method on a private timberland site in southern West Virginia. The goal of the landowner was to apply the deferment harvest method to generate immediate revenue and have continued timber production with a desirable species composition in the regeneration cohort. The intent was to implement this practice on a harvest rotation of 25 years.

\section{Study Objectives}

This study determined if the deferment harvest method is likely to retain timber value and provide desirable stand conditions for next harvest in 25 years on a private timberland site in 
West Virginia. The primary objective of this study was to describe the overall stand structure at four years after harvest of the residual and regeneration cohorts, while quantifying how aspect influences differences in deferment stand conditions. Specifically, the objectives of this study were to: 1) test the impact of epicormic branches on residual tree quality and their effect on current and future lumber value at 25 years after harvest; 2) determine if the canopy of the residual stand influences the species composition and development of the regeneration cohort; and 3) describe variation in timber production and regeneration development between the south and east aspects.

\section{LITERATURE REVIEW}

\section{Part I: Forest Management in Central Appalachian Hardwood Forests}

Central Appalachian hardwood forests are composed of second-growth forests with a species composition comprising a mixture of shade-intolerant and shade-tolerant species (Fajvan et al., 1998; Brashears et al., 2004; Fajvan, 2006). When harvesting these forests, it is often the goal to maintain the species composition that was present before harvest for continual timber production (Brashears et al., 2004; Rosenfeld et al., 2006). The high species diversity in these forests generates opportunities for foresters to apply a silvicultural treatment to help meet specific management objectives in the long-term (Fajvan et al., 1998; Fajvan, 2006; Vickers and Fox, 2015). For example, the goal in forest management is to implement a practice which would meet some primary objective, such as generating profitable timber production, providing suitable wildlife habitat, regenerating more desirable species, and maintaining the aesthetics of the forest (Miller et al., 1995; Miller et al., 1997a; Brashears et al., 2004; Schuler, 2004; Rosenfeld et al., 2006; Thomas-Van Gundy and Schuler, 2008; Greenler and Saunders 2019). 
Partial harvest practices (i.e., diameter-limit cutting) are common management practices in Appalachian hardwood forests on privately owned timberlands (Fajvan et al., 1998).

Diameter-limit harvests favor more shade-tolerant species in the regeneration, such as red maple (Marquis, 1967; Vickers and Fox, 2015; Schuler et al., 2017 Greenler and Saunders, 2019), and displace other desirable, shade-intolerant species, such as yellow-poplar and northern red oak (Schuler and Miller, 1995; Brose et al., 1999; Greenler and Saunders, 2019). This loss of shadeintolerant species reduces the species diversity in the forest stand (Miller and Smith, 1991; Fajvan et al., 1998; Brashears et al., 2004; Schuler, 2004; Schuler et al., 2017). Diameter-limit harvests also found to have a lower number of high-quality trees (i.e., grade 1) in the long-term, with more of these trees harvested than retained (Brown et al., 2017).

Even-aged management practices were initiated in central Appalachian hardwood forests to increase and sustain the species diversity and maintain more high-value species for long-term timber production. These practices promote increasing the species diversity of shade-intolerant, mid-tolerant, and shade-tolerant species (Wendel and Trimble, 1968; Miller and Schuler, 1995; Miller et al., 1995; Miller et al., 1997a; Miller et al., 2004; Miller et al., 2006; Schuler et al., 2017). Clearcut harvests were the first of these practices implemented to restore the species diversity of the central Appalachian hardwood forests, with a mixture of different shade tolerance species, while focusing on regenerating more desirable and commercial shadeintolerant species (Marquis, 1967; Smith, 1981; Beck and Hooper, 1986; Smith and Miller, 1991; Miller and Schuler, 1995; Miller et al., 1995; Arthur et al., 1997; Miller et al., 1997a; Miller et al., 1997b ; Johnson et al., 1998; Brashears et al., 2004; Miller et al., 2004; Miller et al., 2006; Vickers and Fox, 2015). Shade-intolerant species often require some type of disturbance to initiate and establish reproduction (Schuler et al., 2017), and a clearcut is capable of establishing 
the natural disturbance by the removal of all overstory trees. Previous studies indicated clearcut harvests throughout the Appalachian region produce a variety of shade-intolerant and shadetolerant species. For example, shade-intolerant (i.e., yellow-poplar) and shade-tolerant (i.e., red maple) were the dominant species in the stands of these studies, with a low proportion of oak throughout the Appalachian region (McGee and Hooper 1975; Parker and Swank, 1982; Beck and Hooper, 1986; Arthur et al., 1997; Brashears et al., 2004; Vickers and Fox, 2015). This diversity of species contributes to fully stocked stands for sufficient timber supply and low harvesting costs (Marquis, 1967; Vickers and Fox, 2015).

While clearcut harvests can provide both economic and environmental benefits, there is much public opposition and criticism towards the appearance of young clearcut stands from the removal of all overstory trees in one harvest (Smith, 1981; Smith and Miller, 1991; Miller et al., 1995; Miller et al., 1997b; Johnson et al., 1998; Ribe, 2005). The public's expectation of a forest usually includes the presence of numerous large trees and wildlife (Magill, 1992; Ribe, 2005), which creates positive attitude and emotion from the experience of observing standing trees in a forest environment (Ribe, 2005). These experiences match with the public's expectations of the forest in viewing a natural scenery, while the absence of this natural scenery conflicts with those expectations (Magill, 1992; Ribe, 2005). For example, previous studies found clearcut harvests to negatively impact the public's perceptions and experiences from nature compared to a continuous forest scenery (Ribe, 2005; Palmer, 2008). In response to this widespread opposition to clearcutting, foresters and scientists sought to implement alternative options that would address public expectations while continuing to meet the necessary sustainable balance to also benefit the society's view of the forest (Miller et al., 1995; Miller et al., 1997b; Johnson et al., 
1998; Wurtz and Zasada, 2001; Miller et al., 2004; Miller et al., 2006; Thomas-Van Gundy and Schuler, 2008).

The alternative treatment methods foresters seek from conducting a clearcut involve retaining select residual trees for a certain period of time, while retrieving timber value. These different management practices emphasize achieving a specific primary objective. For example, a primary objective for conducting a shelterwood is to retain select residual trees for regeneration purposes. In central Appalachian hardwood forests, shelterwood harvests have been conducted to restore the dominance of oak species (Schuler and Miller, 1995; Brose and Van Lear, 1998; Brose et al., 1999). There has been a need to focus on regenerating oak species in these forests, because oak provides major economic and ecological benefits compared to other hardwood species (Loftis, 1990; Brashears et al., 2004; Greenler and Saunders, 2019). Previous research suggests shelterwood harvests with prescribed fire as an intermediate treatment does favor oak successfully over other competitive hardwood species (i.e., yellow-poplar) (Brose et al., 1999; Greenler and Saunders, 2019).

Compared to a shelterwood harvest, a seed tree harvest retains select trees for a short period of time to provide a more abundant seed bank for abundant regeneration to grow and develop successfully in the forest stand (Johnson and Krinard, 1976; Rosenfeld et al., 2006). Studies focusing on regeneration of both hardwood and softwood species observed development of regeneration from a successful abundant seed bank (Wendel and Trimble, 1968; Smith et al., 1976; Rodríguez-García et al., 2010). Although both of these alternative methods produce abundant regeneration, the residual trees left in the stand are harvested shortly after the initial harvest (Smith et al., 1976). This leaves the stand to appear like a clearcut, and there remains a desire to maintain a continuous forest-like appearance when conducting a harvest. 


\section{Part II: Introducing the Deferment Harvest Method to Central Appalachian Hardwood Forests}

The deferment harvest method was introduced to the central Appalachian region as another alternative method to conducting a clearcut harvest (Köstler, 1956; Troup, 1966; Smith et al., 1989; Miller and Schuler, 1995; Miller, 1996; Miller et al., 1997a; Miller et al., 2004; Thomas-Van Gundy and Schuler, 2008; Brown et al., 2018). It resembles a shelterwood or seedtree stand with select residual trees retained in the forest stand for an extended period of time, as long as between half up to full harvest rotation (i.e., 40-80 years) (Smith et al., 1989; Miller and Schuler, 1995; Miller et al., 1995; Miller, 1996; Miller et al., 1997a; Miller et al., 1997b; Johnson et al., 1998; Miller et al., 2004; Miller et al., 2006; Thomas-Van Gundy and Schuler, 2008; Brown et al., 2018). Also referred to as a two-aged or retention harvest, this silvicultural practice creates a two-aged structure, an older cohort of retained dominant and codominant residual trees with a younger regeneration cohort (Smith and Miller, 1991; Miller and Schuler, 1995; Miller et al., 1997a; Johnson et al., 1998; Thomas-Van Gundy and Schuler, 2008; Brown et al., 2018). Residual trees are often selected to meet the objective of maintaining that balance between timber production, habitat for wildlife, and improving aesthetics (Smith et al., 1989; Miller and Schuler, 1995; Miller et al., 1995; Miller, 1996; Miller et al., 1997a; Miller et al., 1997b; Johnson et al., 1998; Thomas-Van Gundy and Schuler, 2008). The species composition results in a mixture of shade-intolerant and shade-tolerant species, similar to the regeneration found after a clearcut harvest (Smith et al., 1989; Miller and Schuler, 1995; Miller, 1996; Miller et al., 1997a; Johnson et al., 1998; Thomas-Van Gundy and Schuler, 2008). 


\section{Part III: Factors Influencing the Residual Trees in Deferment Stands}

One goal for successfully conducting a deferment harvest is to maintain the quality of the residual trees. However, one drawback to this silvicultural practice is the greater potential for the residual trees to develop epicormic branches. These branches develop from dormant buds along the tree bole in response to various environmental stimuli from changes in environmental conditions (Miller, 1996; Meadows, 1995; Meadows et al., 2013). For example, residual trees have a higher potential to develop epicormic branches when experiencing sudden exposure to sunlight after removal of adjacent codominant trees (Miller, 1996; Meadows et al., 2013).

Epicormic branches lead to the formation of knots and other defects (Miller, 1996; Meadows and Burkhardt, 2001; Meadows et al., 2013). These defects reduce the quality of the tree, which leads to reduced timber volume and timber value (Miller, 1996; Meadows and Burkhardt, 2001; Gordon et al., 2006; Ishii et al., 2007; O’Hara and Berrill, 2009; Meier et al., 2012; Meadows et al., 2013). It is essential for foresters considering the deferment method to select high-quality trees with a lower likelihood to develop epicormic branches as residuals (Miller, 1996; Meadows and Burkhardt, 2001; Meadows et al., 2013). Previous deferment harvest studies in West Virginia found only a small portion $(<10 \%)$ of the residual trees with epicormic branches to reduce in quality (Smith et al., 1989; Miller et al., 1997a). This indicates that even though most of the residual trees did develop epicormic branches at least during the first two years after the harvest, most of the residual trees were able to maintain their quality (Miller, 1996).

Even though only a small portion of residual trees were reduced in quality due to the development of epicormic branches, there remains uncertainty of whether this small impact of epicormic branches extends to a significant loss in timber value. The quality of the tree is the 
primary factor affected by the development of epicormic branches, which can lead to loss in timber value from the residual trees (Miller, 1996; Gansner et al., 1989; Meadows and Burkhardt, 2001; Gordon et al., 2006; Ishii et al., 2007; O’Hara and Berrill, 2009; Meier et al., 2012; Meadows et al., 2013). In addition, diameter and merchantable height of the residual trees can also affect the timber value of the residual trees (Gansner et al., 1989).

\section{Part IV: Factors Influencing the Regeneration Cohort in Deferment Stands}

Another goal for successfully conducting a deferment harvest is to regenerate species with the potential for generating future timber supply. The intent is to regenerate more desired, highly valuable species, such as more shade-intolerant (i.e., yellow-poplar) and mid-tolerant species (i.e., oak), as these species often meet profit expectations. Previous deferment studies in

West Virginia found a mixture of shade-intolerant and shade-tolerant species, similar to that of regeneration when conducting a clearcut (Marquis, 1967; Beck and Hooper, 1986; Brashears et al., 2004; Vickers and Fox, 2015). Black birch (Betula lenta), black cherry (Prunus serotina), red maple, sugar maple (Acer saccharum), and yellow-poplar were dominant species across deferment stands up to at least 20 years after deferment harvest, while northern red oak was also present but in low proportions (Miller and Schuler, 1995; Miller et al., 1997a; Miller et al., 2004; Thomas-Van Gundy and Schuler, 2008).

Different environmental factors can influence the species composition and development of the regeneration cohort. Various light quantities can influence which species will be the most successful and develop into future residual trees. For example, shade-intolerant species require higher light quantities for successful growth and development compared to that of shade-tolerant species. The light quantity reaching the forest floor is dependent on the amount of basal area of 
the residual overstory after harvest (Johnson et al., 1998; Collet et al., 2001). The crowns of the residual trees can reduce the light quantity penetrating to the forest floor, which can influence which species in the regeneration cohort will be the most successful under altered light conditions. Miller et al. $(2004,2006)$ were the first to determine the effect of residual tree canopy on the reproduction in a deferment harvest stand implemented in central Appalachian hardwood forests. The diameter and height of the regeneration 20 years after a deferment harvest were influenced by the canopy from individual residual trees. There remains uncertainty on how the presence of total residual canopy cover in deferment stands influences the species composition and development of the regeneration cohort less than five years after the initial harvest.

\section{Part V: How Aspect Influences Forest Productivity}

Aspect is an important factor in forest management because it influences differences in growth and species composition of both the residual trees and the regeneration cohort (Olivero and Hix, 1998; Måren et al., 2015). Aspect is the direction in which the slope is facing, and influences differences in site conditions based on variations of certain environmental factors. For example, contrasting aspects differ in soil and air temperature, light quantity in relation to the amount of canopy present, and moisture content in the soil. These environmental factors influence variation in the species composition and growth of the forest stand between contrasting aspects (Fekedulegn et al. 2003; Måren et al., 2015). For example, the north and east aspects can retain more moisture and support a mixed hardwood species composition more adaptive to a high moisture environment (i.e., sugar maple, American beech (Fagus grandifolia), yellow-poplar, white oak (Quercus alba), northern red oak) (Figure 1) (Olivero and Hix, 1998). In contrast, the south and west aspects remain drier due to more exposure to sunlight and support a mixed-oak 
species composition (i.e., white oak, chestnut oak (Quercus montana), northern red oak), which are better adapted to environments with lower moisture content (Figure 1) (Olivero and Hix, 1998; Måren et al., 2015). However, the effect of aspect on the productivity from conducting any forest management treatment is lacking in central Appalachian hardwood forests. This study observed the relevance of aspect on deferment harvest stand conditions, specifically observing differences in timber production because of epicormic branches from the residual trees and the species composition and development of the regeneration cohort.

\section{MATERIALS AND METHODS}

\section{Site Description}

The study site is located within the borders of Clay and Nicholas counties in south-central West Virginia, approximately 16 miles west from Summersville (N 38.306071º, W -

$\left.81.152346^{\circ}\right)$. The 880 -acre site is a private, family-owned timberland site. Elevation ranges from 950 to 1650 feet. The soil composition consists of the following soil types: 1) Gilpin soils composed of weathered particles derived from sandstone and siltstone; 2) Lily soils composed of weathered particles derived from sandstone; 3) Laidig and Pineville soils composed of unconsolidated sediments derived from sandstone and siltstone; 4) Buchanan moist soils composed of acid fine-loamy particles derived from sandstone and siltstone; and 5) Craigsville soils composed of fine-grained particles derived from sandstone and shale (Soil Survey Staff, USDA). The mean annual temperature in the Summersville area is $47^{\circ} \mathrm{F}$, with average temperature of $58^{\circ} \mathrm{F}$ during the growing season from April to September (Climate Data Online, 2017). Total annual precipitation is 48 inches, with $59 \%$ occurring during the growing season 
(Climate Data Online, 2017). All stands on the study site have a northern red oak site index of 80 (base age of 50 years) (Soil Survey Staff, USDA).

Deferment harvests were conducted from September 2014 until December 2015.

Residual trees were selected to remain in the stand if they were at least 12 inches in diameter with long-term sawtimber potential, and to retain about 1500 board feet per acre (J. Scronce, Consulting Forester, personal communication). Ten permanent, one-tenth acre circular plots were established by the consulting forester immediately after each area was harvested (Figure 2). The purpose was to monitor annual growth and volume production over time after harvest. The residual trees consisted a variety of commercial hardwood species and a few eastern hemlocks (Tsuga canadensis). Most trees ranged between 16 to 20 inches DBH with some between 10 to 14 inches DBH. All trees greater than or equal to 22 inches were harvested. Of the residual trees, chestnut oak was the dominant species (34\% of total standing stems), followed by hickory (Carya spp.) (12\%), sugar maple (10\%), and white oak (10\%).

\section{Experimental Design}

Aspect was calculated across the study area in ArcMap 10.5 using the aspect spatial analyst tool. Areas of similar aspect that had been harvested were grouped into the following: North $\left(0-90^{\circ}\right)$, East $\left(91-180^{\circ}\right)$, South $\left(181-270^{\circ}\right)$, and West $\left(271-360^{\circ}\right)$. Specifically, differences between south and east aspects were observed based on known contrasting differences, while also comprising $57 \%$ of the total site (493 acres), with south making-up 27\% (234 acres) and east making-up 30\% (259 acres). A total of six stands were evaluated, three on the south aspect and three on the east aspect. 
The number of additional residual plot samples in each stand was calculated based on the average number of regeneration stems recorded in each of 36 milacre regeneration plots within nine of the permanent plots established by the consulting forester. The following formula was used for calculating the number of residual plots to establish in each stand: (Avery and Burkhart, 2002)

$$
n=\left[\frac{(t)(C V)}{A}\right]^{2}
$$

where $n=$ number of plot samples, $t=\mathrm{t}$-test value, $C V=$ coefficient of variation, $A=$ allowable error (set at $10 \%$ ). Regeneration data were used in this calculation due to low sample size of the residual permanent plots. This allowed to reduce the variability in the data collected and analyzed in the residual plots. Nine total residual plots were established randomly in each aspect replicate stand using ArcMap 10.5. Four of the permanent plots were included in the total nine residual plots for each aspect replicate (Figure 3). This was done because methods for establishing and conducting inventory measurements in the permanent plots were similar to how the residual plots in this study were established.

\section{Field Methods}

Each residual plot was located systematically using predetermined GPS points from ArcMap 10.5. To reduce bias, plot centers were located and established regardless of residual tree abundance and stand conditions. For example, factors such as density of vegetative understory, presence of fallen and dead $\operatorname{logs}$ on the forest floor, and quality of residual trees (i.e., dead or live) were not factored in determining the location of each plot. 


\section{Residual Cohort}

Measurements were taken four years after the deferment harvest. One-tenth acre circular residual plots were established in each aspect replicate (Figure 4). Any residual tree at least six inches DBH was included in the inventory.

The following data were obtained for each residual tree: species, diameter, merchantable height, presence of epicormic branches, and tree grade. Merchantable height to eight-inch diameter top was recorded only for trees greater than or equal to 11.5 inches DBH. These measurements were used to estimate volume in board feet following the Doyle log rule. For eastern hemlock trees sampled on site, merchantable height was calculated if the tree was at least nine inches DBH and using the equation from Westfall and Laustsen (2006). This equation was used for eastern hemlock due to merchantable height guidelines being different from that of hardwood trees.

Epicormic branching was recorded as a binary variable based on presence or absence at the time of inventory. Any branch present along the tree bole between one-foot above the tree base up to an eight inch diameter top (i.e., merchantable height) to main branches was classified as an epicormic branch. All epicormic branches assumed to have developed after deferment harvest.

Tree grade was recorded to rate tree quality of the first 16 -foot $\log$, in association with the potential effects of epicormic branches. Tree grade for all trees (except for eastern hemlock) was measured following the guidelines of Miller et al. (1986). However, tree diameter was not factored into determining tree grade in order to evaluate the potential effects of epicormic branches on timber production up to 25 years after deferment harvest. Eastern hemlock trees were graded following grading guidelines from the "Other Softwoods" (see US Forest Service, 
Regional Handbook, Appendix E, 1976). The effect of tree grade due to the presence of epicormic branches was recorded using the following scale: $0=$ no epicormic branches present, 1 $=$ epicormic branches present, but no effect on tree grade, $2=$ epicormic branches present, resulting in one tree grade reduction, and $3=$ epicormic branches are present, resulting in two tree grade reductions.

\section{Regeneration Cohort}

Four milacre circular regeneration plots were established in each cardinal direction (North, South, East, West) and located 18.6 feet from residual plot center. Any stem at least 0.5 feet in height was included in the inventory.

The following data were obtained for each stem within each plot: species, height class, and heights of the top three dominant stems (in feet). The top three dominant heights (to the nearest tenth of a foot) were recorded for each plot by species and measured to the highest live stem and terminal bud.

\section{Canopy Cover Analysis}

At each residual plot, canopy cover (as a percentage) was calculated and measured using a spherical densiometer (Model-C) at five distinct points within each residual plot, one at each regeneration plot center and one at residual plot center. Only canopy visible from the residual trees was recorded for measuring the canopy proportion from each point. Canopy cover was counted if there was certainty of seeing all possible points of canopy from only the residual trees. If there was any uncertainty of the presence of residual tree canopy due to regeneration canopy present, then canopy cover was not counted. An average percentage of residual canopy was 
calculated for each residual plot, with about $75 \%$ of the canopy data points used in calculation for each residual plot. In addition, one residual plot on south aspect marked having no data obtained due to this uncertainty across all five sample points, and therefore was not included in data analysis. A total of 53 average canopy proportions were included in analysis.

\section{Data Analysis}

\section{Effect of Epicormic Branches on Tree Quality and Species}

Residual tree inventory included a total of 217 trees. However, 17 of these trees were classified as recent snags and were excluded from analysis. Only live tree data were analyzed in this study. In addition, one residual tree was recorded as below grade for its tree grade, and was also not included due to insufficient sample size of that tree's quality. Therefore, total of 199 residual trees were statistically analyzed.

Frequency distributions of the presence of epicormic branches by tree grade were analyzed using the Cochran-Mantel-Haenszel Statistics in SAS 9.4 (SAS Institute Inc., 20022010) at significance level $P<0.05$. These tests are a type of contingency table analysis of the distribution and relationship between two categorical variables (i.e., presence of epicormic branches and tree grade) with the presence of a third categorical variable (i.e., aspect). This chisquare test of independence was used to measure if there was a consistent difference across all stands in the proportions of trees with epicormic branches and their associated tree grade. When analyzing these associations with tree grade, grades 2 and 3 were combined due to low abundance in sample for each of those grades. The null hypothesis for these analyses was for the proportion of trees rated grade 1 to be equal to the proportion of trees rated either grade 2 or 3 , given that a tree has epicormic branches. If the null hypothesis was rejected, then an odds ratio 
was calculated to explain the statistical difference in the likelihood of a tree being rated grade 1 given the tree has epicormic branches. Trees rated grade 1 were a main emphasis to assess the effectiveness of the deferment harvest method in maintaining better quality trees. These analyses were conducted on all the residual trees together and separately for only the merchantable size trees. This was to emphasize the conditions of the current merchantable trees for assessing the effect on lumber value from the development of epicormic branches.

\section{Effect of Epicormic Branches on Timber Value}

The present timber value was calculated and projected for the merchantable size residual trees in 2018 up to 25 years after the deferment harvest. Residual tree inventory data was input into SILVAH 7.0 (Stout and Thomasma, 2018) to calculate and project board-foot volumes of these trees for each species up to 25 years from 2014 in intervals of 5 years from time of inventory $(2018,2019,2024,2029,2034,2039)$. SILVAH was the most applicable growth and yield model for calculating the volume for oak-hickory and mixed hardwood forests in West Virginia (Schuler et al., 1993). Projected volumes were input into a series of formulas by the West Virginia University Appalachian Hardwood Center based on tree DBH and assessed tree grade to calculate the present lumber value for each species in each projected year using the following equation:

$$
\mathrm{V}=\sum(B \cdot L)
$$

where $V=$ lumber value, $B=$ lumber prices by species for each lumber quality (see Appendix A), $L=$ lumber volume. And the lumber volume, $L$, was calculated using the following equation:

$$
\mathrm{L}=\sum\left(M \cdot \mathrm{Y}_{F}\right)
$$


where $M=$ board-foot volume calculated using SILVAH, and $Y_{F}=$ expected lumber yield $(\%$ of tree scale by lumber quality) (see Appendix B). Lumber prices for each species and each projected year were included in these calculations based on the quality of the lumber (FAS, \#1C, \#2A, \#3A), along with the proportion of lumber which could be recovered from the sawtimber $\log$ when cut at the sawmill. The total lumber value for each species is the sum of each tree grade with factoring in the lumber quality and values of each species.

The present lumber value from harvest in 2014 for each species was calculated factoring in three different possible rates of return $(4 \%, 6 \%, 8 \%)$. The following equation calculated the net lumber value at each projected year for each species at each rate of return:

$$
V_{0}=\frac{V}{(1+i)^{n}}
$$

where $V_{0}=$ present lumber value, $V=$ lumber value, $i=$ rate of return, $n=$ investment period. The quality and conditions of the residual trees for these calculations were assumed to remain consistent over the simulation time period.

Some species had trees that were downgraded in quality due to the presence of epicormic branches. These species were analyzed to determine if lumber value was lost because of the reduced quality. Two different lumber values were calculated using the formulas from the Appalachian Hardwood Center and projected over 25 years for these species: 1) downgraded value as the tree was with the effect of epicormic branches; and 2) potential value if the tree's quality was not affected by epicormic branches. This analysis assumed there were no other defects present other than the presence of epicormic branches on these specific trees. A simple ttest was conducted to test if the downgraded and potential lumber values were different from 
zero using JMP Pro 12.2 (SAS Institute Inc., 2015). The null hypothesis of this analysis was there was no difference between the downgraded and potential lumber values of these species.

\section{Canopy Cover Influence on Regeneration Cohort}

Species of the regeneration cohort were classified into three shade tolerance classes: shade-intolerant, mid-tolerant, and shade-tolerant. Shade tolerance of each species was classified based on the silvics characteristics of each species (Burns and Honkala, 1990). The total number of all species and the commercial species nested within the total species was summarized and grouped into each of these three shade tolerance classes. A species was classified as commercial if it was known to be harvested for timber products in eastern deciduous forests in the United States (see Appendix C for list of commercial regeneration species).

Species diversity was calculated to summarize the abundance and richness of the species composition of the regeneration cohort on each aspect. Diversity was calculated using the Shannon Diversity Index ( $\left.\mathrm{H}^{\prime}\right)$ to account for measuring both the abundance and species richness of the species composition:

$$
\mathrm{H}^{\prime}=-\sum\left(p_{i}\right) \cdot \ln \left(p_{i}\right)
$$

where $p_{i}=$ proportion of species $=\left(\frac{\text { abundance of one species }}{\text { total species abundance }}\right)$. If the species diversity is greater

than zero $\left(\mathrm{H}^{\prime}>0\right)$, then the species diversity is higher, while if the species diversity is less than zero $\left(\mathrm{H}^{\prime}<0\right)$, then the species diversity is lower. A diversity index was calculated for both the total species composition and the commercial species. Differences in the species richness driving the species diversity between the south and east aspects was measured using the Jaccard Similarity Ratio $\left(\mathrm{C}_{\mathrm{j}}\right)$ : 


$$
\mathrm{C}_{\mathrm{j}}=\frac{a}{a+b+c}
$$

where $a=$ species was present on both the south and east aspect, $b=$ species was present only on the south aspect, $c=$ species was present only on the east aspect. When the ratio is closer to one, species richness is more similar between the south and east aspects. If the species richness is the same among both aspects but the relative abundance of each species is different, then this would indicate one aspect to regenerate greater abundance of one species than the other aspect. Both species similarity and species diversity measures were taken into account to summarize the species composition of the regeneration cohort and observe if there are any differences between the south and east aspects.

The effect of canopy cover on species diversity, stem density of each shade tolerance class, and average dominant height were analyzed independently using analyses of covariance (ANCOVAs) in SAS 9.4 (SAS Institute Inc., 2002-2010) at significance level $P<0.05$. A statistical trend was noted if $0.05<P<0.10$. These analyses were used to observe the differences in means between the south and east aspects and if the response variable can be explained based on the amount of canopy cover. The null hypothesis for these analyses was for there to be no interaction between canopy cover and aspect, and for the slope of the south and east aspect regression lines for each response variable to be equal. For example, the null hypothesis for the response of species diversity is the same between the south and east aspects, regardless of the amount of canopy cover. Violation of normality assumptions required the use of cube transformed values for analyzing species diversity and log transformed values for analyzing stem density of shade-intolerant and mid-tolerant species. Stem density of shade-tolerant species and average dominant heights did meet the normality test assumptions. 


\section{RESULTS}

\section{Epicormic Branch Impact on Residual Tree Quality}

\section{Residual Cohort Inventory}

The residual tree cohort inventory four years after harvest included 199 trees belonging to 16 species. On the south aspect, 104 trees were inventoried belonging to 12 species, with an average of 40 trees per acre, 45.7 square feet of basal area per acre, and average DBH of 15.2 inches. Chestnut oak was the dominant species comprising $44.8 \%$ of the trees and 20.7 feet of basal area per acre on the south aspect (Figure 5A). On the east aspect, 95 trees belonging to 13 species were inventoried, with an average of 36 trees per acre, 45.7 square feet of basal area per acre, and average DBH of 16.1 inches. Hickory and chestnut oak were the dominant species comprising $24.2 \%$ and $19.0 \%$ of the trees and 9.9 and 9.5 square feet of basal area per acre on the east aspect, respectively (Figure 5B). There was no difference in the total square feet basal area per acre present between the south and east aspects $(t=-0.13, P=0.90)$.

Out of the 104 trees on the south aspect, $84.8 \%$ were merchantable size with an average timber volume of 3,787 board feet per acre. Chestnut oak produced an average timber volume of 1,644 board feet per acre, followed by 584 and 399 board feet per acre for black oak (Quercus velutina) and red maple, respectively (Figure 6A). In contrast, out of the 94 trees on the east aspect, $83.2 \%$ were merchantable size with an average timber volume of 4,345 board feet per acre. Chestnut oak produced the greatest timber volume with an average of 930 board feet per acre, followed by 874,642 , and 632 for hickory, white oak, and yellow-poplar, respectively (Figure 6B). There was no difference in the amount of volume per acre present in the stands between the south and east aspects $(t=-0.54, P=0.60)$. This supports the consistency in the amount of basal area left across all stands. 


\section{Effect of Epicormic Branches on Tree Quality and Species}

For all the residual trees, $88.4 \%$ developed epicormic branches somewhere along the merchantable bole. Of those trees with epicormic branches, $68.2 \%$ were rated grade 1 , while $31.8 \%$ were rated either grade 2 or 3 . The proportions of trees rated grade 1 or rated either grade 2 or 3 were different between the presence or absence of epicormic branches $\left(Q_{S M H}=7.47, P=\right.$ 0.0063). Trees with epicormic branches had a $9.7 \%$ likelihood of being rated grade 1 compared to trees without epicormic branches (OR 0.097, 95\% CI 0.013-0.74). There were more trees with epicormic branches rated grade 1 than expected. There were no differences between species with enough trees with epicormic branches for analysis $\left(Q_{S M H}=13.6, P=0.06\right)$. This indicates that epicormic branches were present among all these species equally. For example, all red maple (20 trees), black oak (17 trees), and white oak (16 trees) developed epicormic branches, while $90.8 \%$ of the chestnut oak trees developed epicormic branches (Table 1).

On the south aspect, $91.3 \%$ of all the residual trees developed epicormic branches distributed across all diameter classes (Figure 7A). Of those trees with epicormic branches, $64.2 \%$ were rated grade 1 , while $35.8 \%$ were rated either grade 2 or 3 (Table 2). In contrast, on the east aspect, $85.3 \%$ of all the residual trees developed epicormic branches distributed across all diameter classes (Figure 7B). And of those trees with epicormic branches, $72.8 \%$ were rated grade 1 , while $27.2 \%$ were rated either grade 2 or 3 (Table 2 ). The proportions of trees rated grade 1 or rated either grade 2 or 3 were different between the presence or absence of epicormic branches expected on both the south and east aspects $\left(Q_{S M H}=6.95, P=0.0084\right)$. Trees with epicormic branches had a $10 \%$ likelihood of being rated grade 1 compared to trees without epicormic branches between the south and east aspects $(O R=0.10,95 \% C I 0.01-0.78)$. There 
were more trees with epicormic branches rated grade 1 than expected. Although the proportions of trees were different between the presence or absence of epicormic branches, the proportion of trees having epicormic branches on the south aspect was not different from the proportion of trees having epicormic branches on the east aspect $\left(Q_{S M H}=1.28, P=0.26\right)$.

When assessing only the merchantable size trees, $90.9 \%$ developed epicormic branches on the south aspect, with $67.5 \%$ rated grade 1 , while $32.5 \%$ were rated either grade 2 or 3 . In contrast, on the east aspect, $82.3 \%$ of the merchantable size trees developed epicormic branches, with $80.0 \%$ rated grade 1 , while $20.0 \%$ were rated either grade 2 or 3 (Table 2 ). The proportions of the merchantable size trees rated grade 1 or rated either grade 2 or 3 were different between the presence or absence of epicormic branches expected on both the south and east aspects $\left(Q_{S M H}\right.$ $=4.46, P=0.035)$. Merchantable size trees with epicormic branches had a $14 \%$ likelihood of being rated grade 1 compared to trees without epicormic branches between the south and east aspects $(O R=0.14,95 \% C I 0.02-1.11)$. There were more trees with epicormic branches rated grade 1 than expected. Although the proportions of trees were different between the presence or absence of epicormic branches, the proportion of trees having epicormic branches on the south aspect was not different from the proportion of trees having epicormic branches on the east aspect $\left(Q_{S M H}=13.6, P=0.06\right)$.

\section{Differences in Timber Value by Aspect}

According to the current stand conditions, the south aspect had 2,720 board feet per acre and was worth $\$ 1,596$ dollars in lumber value per acre, while the east aspect had 3,057 board feet per acre and was worth $\$ 1,668$ dollars in lumber value per acre at time of inventory in 2018 . Chestnut oak generated the highest lumber value per acre in 2018 on both the south and east 
aspects. Black oak generated the next highest lumber value on the south aspect ( $\$ 279$ per acre) behind chestnut oak, followed by red maple ( $\$ 157$ per acre). In contrast, sugar maple and hickory generated the second and third next highest lumber values on the east aspect (\$278 and \$260 per acre, respectively) behind chestnut oak (Table 3). Oak species (i.e., chestnut oak, black oak, white oak, and northern red oak) in total comprised $82.1 \%$ of the total lumber value generated on the south aspect in 2018 , while they comprised $50.7 \%$ of the total lumber value generated on the east aspect.

When projecting the stand conditions up to 25 years after the deferment harvest in 2014 , total volume production was expected to increase on both the south and east aspects, with no difference in the amount of board feet produced between the aspects (Figure 8). Both the south and east aspects generated an increased annual rate of return up to year 2024 and maintained the rate of return between $4 \%$ and $6 \%$ (Figure 9). The present lumber value generated from the volume increased at $4 \%$ interest on both the south and east aspects, while the total value was reduced overtime at $6 \%$ and $8 \%$ interest (Figure 10).

When projecting the value of each species on each aspect up to 25 years, chestnut oak continued to generate the highest present lumber value per acre at all three rates of return on both the south and east aspects compared to the other hardwood species (Figure 11). At 4\% interest, chestnut oak increased in lumber value on both the south and east aspects, while the lumber value decreased at $6 \%$ and $8 \%$ interest. Specifically, on the south aspect, other oak species (black oak, white oak, and northern red oak) increased and maintained a higher lumber value up to 25 years at all three rates of return compared to that of the other hardwood species. Red maple, white oak, and northern red oak had similar present lumber values in year 2019, until year 2039 when white oak and northern red oak had a higher value than red maple. Oak species maintained 
a positive rate of return at $4 \%$ interest, with a higher gain by year 2024 on the south aspect, while red maple in comparison had a lower and decreased rate of return. All hardwood species maintained the same chronological order of generated present lumber value per acre, while all species had reduced rate of return over 25 years on the south aspect at $6 \%$ and $8 \%$ interest.

In contrast to the south aspect, hickory and sugar maple were reduced in present lumber value on the east aspect, while white oak increased in value over 25 years. White oak generated a higher present lumber value per acre by year 2039 than hickory and sugar maple at $4 \%$ expected rate of return. White oak also continued to generate a higher value over 25 years compared to hickory and sugar maple $6 \%$ and $8 \%$ expected rate of return. Oak species (black oak, white oak, and northern red oak) increased in present lumber value per acre over 25 years at $4 \%$ interest, while value was maintained and decreased at $6 \%$ and $8 \%$ rates of return, respectively (Figure 12).

\section{Effect of Epicormic Branches on Timber Value}

Although the majority of the merchantable size trees had epicormic branches and were rated grade 1, the lumber value of few of these trees was impacted due to the presence of epicormic branches downgrading trees to being rated either grade 2 or 3 . These trees would have been rated grade 1 if the epicormic branches were not affecting the first 16-foot merchantable log for rating the tree's quality. Ten trees of five species total were downgraded to either grade 2 or 3 due to the presence of epicormic branches between the south and east aspects (Table 4). Black oak, chestnut oak, and white oak comprised five of those trees across all stands. Other species that were downgraded in quality included American beech, hickory, and red maple. 
On the south aspect, there were seven total trees across four species downgraded in tree quality due to the presence of epicormic branches. When projecting the present lumber value per acre of these species over 25 years, black oak and white oak both increased in value at $4 \%$ interest, while both species decreased in value at $6 \%$ and $8 \%$ expected rates of return (Figure 13A \& 13B). In this area, American beech is a low value species, and maintained its low value over 25 years at all three rates of return, while red maple decreased in value over 25 years at all three rates of return. Similar patterns in lumber value were observed for calculating the potential value if epicormic branches did not affect the quality of the trees. There was not enough statistical evidence to note a difference between the downgraded and potential values of all species on the south aspect for each rate of return.

On the east aspect, hickory and white oak had three total trees downgraded in tree quality due to the presence of epicormic branches. When projecting the present lumber value per acre of these species over 25 years, hickory decreased in value at all three rates of return for both its downgraded and potential lumber values (Figure 13C \& 13D). In contrast, white oak increased in lumber value for both its downgraded and potential values at $4 \%$ expected rate of return, then maintained a constant value at $6 \%$ expected rate of return, and was parallel with hickory to reduce in lumber value at $8 \%$ expected rate of return. However, the differences between the downgraded and potential lumber values for both hickory and white oak for each rate of return were not different for both species. 


\section{Canopy Cover Influence on Regeneration Cohort}

\section{Regeneration Cohort Inventory}

The regeneration cohort on the south aspect included 24 species, with 14 classified as commercial (Table 5). The commercial species comprised more than half of the total species and $85.4 \%$ of the total stems per acre on the south aspect. In contrast, the east aspect included 33 species, with 13 classified as commercial (Table 5). The commercial species comprised almost half of the total species and $57.4 \%$ of the total stems per acre on the east aspect. Of the commercial species, red maple was dominant on the south aspect comprising an average of 6,093 stems per acre, followed by chestnut oak (4,009 stems per acre) and yellow-poplar (1,880 stems per acre) (Figure 14A). Of all the species total, seven that were not classified as commercial comprised $27.0 \%$ of the total stems per acre on the south aspect. In contrast, yellow-poplar was dominant on the east aspect comprising an average of 3,546 stems per acre, followed by red maple (1,954 stems per acre) and chestnut oak (1,602 stems per acre) (Figure 14B). Of all species, 16 were not classified as commercial and comprised $28.0 \%$ of the total stems per acre on the east aspect.

\section{Effect of Canopy Cover and Aspect on the Species Composition}

Total tree species diversity was higher on the east aspect $\left(\mathrm{H}^{\prime}=2.96\right)$ compared to the south aspect $\left(H^{\prime}=2.63\right)$. Species richness contributes to this difference, with a greater number of species representing mid-tolerant and shade-tolerant classes on the east than on the south aspect

(Table 6). This is supported by the Jaccard Similarity ratio, which indicated a marginal similarity in species richness between the south and east aspects $\left(\mathrm{C}_{\mathrm{j}_{\text {Total }}}=0.68\right)$. For only the commercial species of the regeneration, species diversity was higher on the east aspect $\left(H^{\prime}=1.96\right)$ than on 
the south aspect $\left(H^{\prime}=1.84\right)$. In this case, species abundance explains this difference between the two aspects for the commercial species. This observation was supported by the Jaccard Similarity ratio, which indicated that the commercial species composition on both the south and east aspects was the same $\left(\mathrm{C}_{\mathrm{j}_{\text {Commercial }}}=0.94\right)$, with only one more shade-intolerant species present on the south aspect than the east aspect (Table 6).

Although there was no main effect of canopy cover on species diversity, there was a difference in species diversity between the south and east aspects when controlling for canopy cover as a covariate $(F=7.82, P=0.0074)$. Stands on the east aspect had a higher species diversity than the stands on the south aspect, regardless of the amount of canopy cover present, with both south and east aspects increasing in diversity as canopy cover increases at the same rate (Figure 15A). There was no effect of canopy cover on species diversity of the commercial species $(F=1.08, P=0.30)$, nor was there an effect on aspect when controlling for canopy cover (Figure $15 \mathrm{~B}, F=0.72, P=0.40$ ). This supports the similarity in species composition between the south and east aspects for the commercial species.

All shade tolerance groups were represented across both the south and east aspects. Although there were a different number of species on each aspect for each shade tolerance group, the number of stems per acre of the shade-intolerant and shade-tolerant species was not different between the south and east aspects $(t=0.39, P=0.69 ; t=0.09, P=0.93$, respectively). However, the mid-tolerant tolerant species had greater stems per acre on the south aspect in contrast to the east aspect (Figure 16A, $t=2.45, P=0.018$ ). The same patterns of average stems per acre were observed for the commercial species only, with only the mid-tolerant species having greater stems per acre on the south aspect in contrast to the east aspect (Figure 16B, $t=$ 2.64, $P=0.01)$. Commercial stems on the south aspect comprised $51.7 \%$ of the total shade- 
intolerant average stems per acre, $99.0 \%$ of the mid-tolerant stems, and $67.8 \%$ of the total shadetolerant stems per acre. In contrast, commercial stems on the east aspect comprised $81.2 \%$ of the total shade-intolerant average stems per acre, $93.0 \%$ of the mid-tolerant stems, and $29.2 \%$ of the shade-tolerant stems per acre.

The relationship between canopy cover and stem density of the shade-intolerant species was not different between the south and east aspects (Figure 17A, $F=0.41, P=0.53$ ), in addition to the shade-tolerant species (Figure $17 \mathrm{~B}, F=0.15, P=0.70$ ). When controlling for canopy cover, stem density of the mid-tolerant species showed a differential trend between the south and east aspects (Figure 17C, $F=3.44, P=0.07$ ), with more stems per acre found on the south aspect. For only the commercial stems, the relationship between canopy cover and stem density of the shade-intolerant species was not different between the south and east aspects (Figure 17D, $F=0.65, P=0.43$ ), with a similar relationship for the shade-tolerant stems (Figure $17 \mathrm{E}, F=2.51, P=0.12$ ). Stem density of the mid-tolerant commercial stems was affected by canopy cover, both regardless of aspect $(F=4.69, P=0.04)$ and when canopy cover was controlled indicating a difference between the south and east aspects (Figure 17F, $F=4.34, P=$ $0.04)$.

\section{Effect of Canopy Cover on Dominant Height}

Non-commercial species comprised $41.0 \%$ of the total dominant stems per acre on the south aspect, and $40.0 \%$ on the east aspect. The tallest average height of the dominant stems was 12.7 feet for pawpaw (Asimina triloba) on the south aspect and hophornbeam (Ostrya virginiana) on the east aspect. Sourwood (Oxydendrum arboreum) comprised the most dominant non-commercial stems per acre on the south aspect, followed by blackgum (Nyssa sylvatica) and 
sassafras (Sassafras albidum) (Table 7A). In contrast, on the east aspect, redbud (Cercis

canadensis) had the greatest stems per acre of the dominant non-commercial species, followed by spice bush (Lindera benzoin) and blackgum (Table 7B). Of the commercial species on the south aspect, red maple had the highest mean stems per acre of the dominant stems, followed by birch and chestnut oak. Red maple had an average dominant height on the south aspect of 8.8 feet, while birch and chestnut oak were 5.7 and 7.4 feet, respectively (Table 7A). In contrast, sugar maple on the east aspect comprised most of the dominant commercial stems per acre, followed by birch and yellow-poplar. Sugar maple had an average dominant height on the east aspect of 7.9 feet, while birch and yellow-poplar were 7.4 and 4.4 feet, respectively (Table 7B). Oak species in the regeneration (chestnut oak, northern red oak, black oak, and white oak) comprised less than $10 \%$ of the dominant stems per acre on the south aspect for each species, as well as less than $5 \%$ of the dominant stems per acre on the east aspect.

The relationship between canopy cover and average dominant height was not different between the south and east aspects for all species (Figure 18A, $F=0.27, P=0.61$ ) and for only the commercial species (Figure 18B, $F=2.05, P=0.16$ ). However, when controlling for canopy cover, there was a differential trend between the south and east aspects for average dominant height of the commercial species $(F=3.17, P=0.08)$, with the dominant stems on the south aspect having a greater average height than the stems on the east aspect.

\section{DISCUSSION}

\section{Effect of Epicormic Branches on Tree Quality}

This study observed the impact of developing epicormic branches on the quality of the residual trees and their effect on the current and future present lumber value through 25 years. 
The residual trees were selected before harvest as the highly vigorous (i.e., codominant crown class) and best quality trees in the stands for timber production (i.e., rated grade 1) (J. Scronce, Consulting Forester, personal communication). These codominant and good quality trees often have a lower likelihood of developing epicormic branches based on species and growth habit observed at the time of harvest (Strong and Erdmann, 2000; Meadows and Burkhardt, 2001; Meier et al., 2012; Meadows et al., 2013), and were expected to maintain their quality until the next intended harvest. Although high quality trees were retained in these stands, the majority of the trees on both the south and east aspects developed epicormic branches (Figure 7). The development of epicormic branches is often the greatest cause of reduced tree quality (Miller, 1996; Meadows and Burkhardt, 2001; Johnson et al., 1998; Gansner et al., 1989). However, this current study and other few deferment studies noted that these residual trees were able to maintain their quality, even with the development of epicormic branches four years after deferment harvest (Miller, 1996; Miller et al., 1997a; Strong and Erdmann, 2000; Meadows and Burkhardt, 2001). Previous deferment harvest studies in West Virginia also observed more residual trees to maintain their quality than expected (Smith et al., 1989; Miller, 1996; Miller et al., 1997a).

Different environmental factors can alter the stand conditions after harvest, which can influence the development of epicormic branches on the residual trees. For example, increase in exposure to sunlight due to canopy removal from harvest is often the main contributing factor for the development of epicormic branches (Meadows, 1995; Meier et al., 2012; Meadows and Burkhardt, 2001; Meadows et al., 2013). The initial development and release of the dormant buds into epicormic branches is dependent on the amount of light penetrating in the forest stand and reaching the tree bole (Meier et al., 2012; Meadows and Burkhardt, 2001; Meadows et al., 
2013). In relation to aspect, one would expect that trees on the south aspect would more likely develop epicormic branches compared to the east aspect due to more direct exposure to sunlight (Fekedulegn et al., 2003; Måren et al., 2015). However, this study indicated the number of residual trees that developed epicormic branches was equal between the south and east aspects.

In addition, the amount of light penetrating in the forest stand is dependent on the amount of total basal area the residual trees occupy in the stands (Johnson et al., 1998; Collet et al., 2001). Strong and Erdmann (2000) observed dominant and codominant red maple residual trees at different basal area levels and found red maple to develop epicormic branches, especially at their lower basal area treatment of 40 square feet per acre. This current study had a similar basal area (45.7 square feet per acre) on both the south and east aspects, with more than three-quarters of the residual trees on both aspects developing epicormic branches. This indicates that because there was no difference in the amount of basal area retained in the stands, the amount of sunlight exposure on both the south and east aspects was the same.

Previous studies also describe epicormic branches to develop more on the upper merchantable logs closer to the tree crown than on the first merchantable log (Meadows, 1995; Miller, 1996; Meadows and Burkhardt, 2001; O’Hara and Berrill, 2009; Meier et al., 2012). This indicates that the location in which the epicormic branches develop influences the quality of the tree. Epicormic branches can develop more on the upper merchantable logs, even of highly vigorous trees, as a benefit for maintaining the tree's health when under stress due to changes in environmental conditions from a partial harvest (Ishii and Ford, 2001; Meier et al., 2012). Although location of the epicormic branches by merchantable log was not recorded in this study, there was potential for more epicormic branches to have developed beyond the first merchantable log. 


\section{Effect of Epicormic Branches on Timber Value}

Oak species were dominant and comprised of the highest present lumber value on both the south and east aspects (Figures $11 \& 12$ ). In addition, almost all of these trees developed epicormic branches, but only had a few trees reduce in quality because of the epicormic branches. At the tree level, Meadows and Burkhardt (2001) emphasized the effect of epicormic branches of willow oak, and observed epicormic branches reduced the timber value. However, at the stand level in this current study, the total present lumber value of the oak species was not reduced due to the presence of epicormic branches. Oak species are documented to be more prone to develop epicormic branches than other hardwood species, which would then lead to loss in timber value (Miller, 1996; Gansner et al., 1989; Meadows and Burkhardt, 2001; Gordon et al., 2006; Ishii et al., 2007; O'Hara and Berrill, 2009; Meier et al., 2012; Meadows et al., 2013). But in the deferment stands, the oak trees were able to maintain their quality, even with the development of epicormic branches. This generates an advantage for the oak trees in the residual cohort to maintain their quality and generate more lumber value over 25 years compared to other species in deferment stands.

\section{Effect of Canopy Cover on the Regeneration Cohort}

It is important to assess if deferment harvest is capable of maintaining the species diversity of shade-intolerant and shade-tolerant species similar to that of conducting a clearcut (Marquis, 1967; Smith, 1981; Beck and Hooper, 1986; Smith and Miller, 1991; Miller and Schuler, 1995; Miller et al., 1995; Miller et al., 1997a; Johnson et al., 1998; Brashears et al., 2004; Miller et al., 2006; Vickers and Fox, 2015). Deferment studies in West Virginia indicated the regeneration species composition was representative of a clearcut harvest at five years after 
harvest (Smith et al., 1989; Miller and Schuler, 1995; Thomas-Van Gundy and Schuler, 2008). In this current study, results were similar with different shade tolerance classes represented across all stands (Figure 16), also representing a composition similar to a clearcut at four years after deferment harvest (Brashears et al., 2004). This high species richness in the regeneration was expected, as the stands were at the early stages of stand development. For example, during the early stages of stand development, the shade-intolerant species are noticeable and abundant in early development, while the shade-tolerant species will gain dominance in the stand later in development (Brashears et al., 2004; Vickers and Fox, 2015).

There was also much variation of commercial and non-commercial species dominating the regeneration stems four years after deferment harvest. The east aspect had a higher species diversity compared to the south aspect with greater non-commercial species abundance (Figure 15) comprising almost half of the dominant stems on both aspects (Tables 7A and 7B). The east aspect has a higher moisture content, lower light quantity, and cooler soil and air temperatures to allow a mixed-hardwood species composition to regenerate, resulting in a higher species richness (Olivero and Hix, 1998; Fekedulegn et al. 2003; Måren et al., 2015). In contrast, the south aspect had a lower species diversity, but with more mid-tolerant stems per acre expected, with lower moisture content and higher light quantities (Olivero and Hix, 1998; Måren et al., 2015).

When observing the canopy from the residual trees, variations in light conditions among the forest stand can also influence the development of the different tolerance species in the regeneration cohort. For example, shade-intolerant species, such as yellow-poplar, are more likely to outcompete other species under high light conditions, while in lower light levels, the shade-tolerant species can compete better than the shade-intolerant species (Brashears et al., 
2004). These interactions occur more during the later stages of development, where there is an increase in competition for resources and dominance in the stands.

These observations in the regeneration cohort would be expected at the later stages of stand development after conducting a deferment harvest. For example, Miller et al. (2004) examined the association between the DBH and height of the regeneration 20 years after a deferment harvest in West Virginia in relation to the crown of specifically select northern red oak residual trees. Northern red oak is documented to generate the largest crown compared to other hardwood species at a certain age (Lamson, 1987). The canopy from these residual trees had an effect on both the shade-intolerant and mid-tolerant species dependent on the amount of light penetrating from the canopy. The crown size of the residual trees is dependent on the species and basal area of the residual trees, which then are dependent on the amount of sunlight penetrating to the forest floor and exposed to the regeneration stems (Newsome et al., 2010). This indicates that the regeneration will become effected by the canopy from the residual trees, where the crowns of the residual trees are expected to expand, while the regeneration cohort continues to establish to canopy closure (Miller et al., 2004).

Oak is the primary species comprising the mid-tolerant stems, and are expected to have a greater abundance on the south aspect (Olivero and Hix, 1998; Måren et al., 2015). However, when observing across all deferment stands, oak species comprised a lower abundance of dominant stems compared to all species. Even at 10 up to 20 years after conducting a deferment harvest, northern red oak specifically was present but only in low abundance (Miller and Schuler, 1995; Miller et al., 2004; Thomas-Van Gundy and Schuler, 2008). Forest management strategies sought to focus on the management and regeneration of oak in Appalachian hardwood forests, because of its high and beneficial economic and ecological values (Loftis, 1990; Brashears et al., 
2004; Greenler and Saunders, 2019). For example, shelterwood harvests with prescribed fire as an intermediate treatment have been examined as a successful treatment for regeneration of oak (Loftis, 1990; Brose et al., 1999; Greenler and Saunders, 2019). Based on the deferment stand structure, production of high-value lumber, and the species composition of both the residual and regeneration cohorts, retaining the residual trees for an extended period of time would be beneficial for the regeneration of oak with a suitable and reasonable intermediate treatment, such as prescribed fire.

\section{CONCLUSIONS}

The deferment harvest method is an alternative forest management treatment to conducting a clearcut. In contrast to shelterwood and seed tree treatments, a deferment harvest retains select residual trees in the stand after harvest for an extended period of time. The primary objective of the deferment harvest is to address improving aesthetics with maintaining a forestlike structure in the stands. This current study suggested that even though almost all of the residual trees developed epicormic branches, the majority were rated grade 1 and were able to maintain their quality at four years after the harvest. Of these residual trees, oak species were projected to generate a higher lumber value and increase in value over 25 years. In addition, the regeneration cohort consisted of a variety of different species at four years after harvest. In addition to improving aesthetics, it is possible for the deferment harvest method to regenerate a desirable species composition similar to that of conducting a clearcut, with the possibility of focusing on the regeneration of oak species. Determining the most suitable level of basal area of these deferment stands would be essential for regenerating oak. The deferment harvest method is 
capable of retaining lumber value and providing desirable stand conditions over an extended period of time.

\section{ACKNOWLEDGEMENTS}

This research was accomplished with collaboration and assistance of different individuals in and out of the forestry field. First, thanks go to my major advisor and committee chair, Dr. Jamie Schuler, along with fellow graduate committee members, Dr. David McGill and Dr. Melissa Thomas-Van Gundy, for advising and providing feedback for this work. This project would not have been possible without the funding from the United States Forest Service and the Dr. Kenneth L. Carvell Fellowship from the West Virginia University Davis College of Agriculture, Natural Resources and Design.

Second, I would like to acknowledge the Jones family for their initiative to seek guidance and expertise on management of their forest land. The hope is that the information presented from this work will be applicable to continue successfully managing their forest. In addition, for the family in collaboration with Dave Calhoun, logger and land manager, for permission to utilize the site for this work to test and understand more about the deferment harvest method. Jim Scronce, Consulting Forester, is also acknowledged for collaboration and his expertise about the forest site, as well as guidance for the work.

Third, for the field work portion of the project, I would like to thank Alex Beezel for her dedication and assistance with the field data collection and measurements. In addition, Olakunle Sodiya, David Blades, and Michael Friddle for their willingness to volunteer their time for finishing data collection towards the end of the field season. 
And finally, for the data analysis portion of the project, I would like to thank Ida Holásková, Statistician in the Davis College of Agriculture, Natural Resources and Design, for assistance and guidance with running the statistical analyses. I would also like to thank Dr. Todd Ristau and Dr. Scott Thomasma from the Northern Research Station of the United States Forest Service with their assistance in projecting 25-year data using SILVAH. 


\section{LITERATURE CITED}

Arthur, M.A., Muller, R.N., Costello, S., 1997. Species composition in a central hardwood forest in Kentucky 11 years after clear-cutting. Am. Mid. Nat. 137, 274-281.

Avery, T.E., Burkhart, H.E., 2002. Forest Measurements. Long Grove, IL: Waveland Press, Inc.

Beck, D.E., Hooper, R.M., 1986. Development of a southern Appalachian hardwood stand after clearcutting. South. J. Appl. For. 10, 168-172.

Brashears, M.B., Fajvan, M.A., Schuler, T.M., 2004. An assessment of canopy stratification and tree species diversity following clearcutting in central Appalachian hardwoods. Forest. Sci. 50, 54-64.

Brose, P., Van Lear, D., Cooper, R., 1999. Using shelterwood harvests and prescribed fire to regenerate oak stands on productive upland sites. Forest. Ecol. Mang. 113, 125-141.

Brown, J.P., Thomas-Van Gundy, M.A., Schuler, T.M., Wiedenbeck, J.K., 2017. Silvicultural prescriptions influence the proportion of high-quality hardwood butt-logs harvested over a half-century of management. For. Sci. 64, 203-213.

Brown, J.P., Thomas-Van Gundy, M.A., Schuler, T.M., 2018. Overstory cohort survival in an Appalachian hardwood deferment cutting: 35-year results. Forest Ecol. Manag. 421, 5458.

Burns, R.M., Honkala, B.H., 1990. Silvics of North America: 1. Conifers; 2. Hardwoods. Agriculture Handbook 654. U.S. Department of Agriculture, Forest Service, Washington DC. Vol. 2, 1-877.

Carvell, K.L., Perkey, A.W., 1997. Using diagnostic plants to evaluate site class. NA-TP-03-97, Morgantown, WV: U.S. Department of Agriculture, Forest Service, Northeastern Area State and Private Forestry. p. 6.

Collet, C., Lanter, O., Pardos, M., 2001. Effect of canopy opening on height and diameter growth in naturally regenerated beech seedlings. Ann. For. Sci. 58, 127-134.

Dale, M.E., Smith, H.C., Pearcy, J.N., 1995. Size of clearcut opening affects species composition, growth rate, and stand characteristics. Res. Pap. NE-698, Radnor, PA: U.S. Department of Agriculture, Forest Service, Northeastern Forest Experiment Station. 1-21.

Fajvan, M.A., Grushecky, S.T., Hassler, C.C., 1998. The effects of harvesting practices on West Virginia's wood supply. J. Forest. 96, 33-39.

Fajvan, M.A., 2006. Research on diameter-limit cutting in central Appalachian forests. In:

Kenefic, L.S., Nyland, R.D., eds. Proceedings of the conference on diameter-limit cutting 
in northeastern forests, 2005 May 23-24, Amherst, MA. Gen. Tech. Rep. NE-342, Newtown Square, PA: U.S. Forest Service. 32-38.

Fekedulegn, D., Hicks Jr., R.R., Colbert, J.J., 2003. Influence of topographic aspect, precipitation and drought on radial growth of four major tree species in an Appalachian watershed.

Forest. Ecol. Mang. 177, 409-425.

Gansner, D.A., Arner, S.L., Birch, T.W., 1989. Timber value growth rates in New England. Res. Pap. NE-632. Radnor, PA: U.S. Department of Agriculture, Forest Service, Northeastern Forest Experiment Station. 1-14.

Gordon, D., Rosati, A., Damiano, C., Dejong, T.M., 2006. Seasonal effects of light exposure, temperature, trunk growth and plan carbohydrate status on the initiation and growth of epicormic shoots in Prunus persica. J. Hortic. Sci. Biotech. 81, 421-428.

Greenler, S.M., Saunders, M.R., 2019. Short-term, spatial regeneration patterns following expanding group shelterwood harvests and prescribed fire in the central hardwood region. Forest. Ecol. Mang. 432, 1053-1063.

Ishii, H., Ford, E.D., 2001. The role of epicormic shoot production in maintaining foliage in old Pseudotsuga menziesii (Douglas-fir) trees. Can. J. Bot. 79, 251-264.

Ishii, H.T., Ford, E.D., Kennedy, M.C., 2007. Physiological and ecological implications of adaptive reiteration as a mechanism for crown maintenance and longevity. Tree. Physiol. $27,455-462$.

JMP, Version Pro 12.2. 2015. SAS Institute Inc., Cary, NC.

Johnson, J.E. Miller, G.W., Baumgras, J.E. West, C.D., 1998. Assessment of residual stand quality and regeneration following shelterwood cutting in central Appalachian hardwoods. North. J. Appl. For. 15, 203-210.

Johnson, J.S., Caldwell, D., Johnson, A., 2018. Hardwood Market Report. Memphis, TN.

Johnson, R.L., Krinard, R.M., 1976. Hardwood regeneration after seed tree cutting. Res. Pap. SO-RP-123, New Orleans, LA: U.S. Department of Agriculture, Forest Service, Southern Forest Experiment Station. 1-9.

Köstler, J.N., 1956. Silviculture. Anderson, M.L., trans. Aylesbury and London: Oliver and Boyd Ltd. 1-416.

Lamson, N.I., 1987. DBH/Crown diameter relationships in mixed Appalachian hardwood stands. Res. Pap. NE-610, Radnor, PA: U.S. Department of Agriculture, Forest Service, Northeastern Forest Experiment Station. 1-3. 
Local Climatological Data Map, Climate Data Online. 2017. National Centers for Environmental Information. gis.ncdc.noaa.gov/maps/ncei/lcd. Accessed 3 August 2018.

Local Climatological Data Map, Climate Data Online. 2017. National Centers for Environmental Information. gis.ncdc.noaa.gov/maps/ncei/lcd. Accessed 3 August 2018.

Loftis, D.L., 1990. A shelterwood method for regenerating red oak in the southern Appalachians. Forest. Sci. 36, 917-929.

Magill, A.W., 1992. Managed and natural landscapes: what do people like? Res. Pap. PSW-RP213, Albany, CA: Pacific Southwest Research Station, Forest Service, U.S. Department of Agriculture. 1-28.

Måren, I.E., Karki, S., Prajapati, C., Yadav, R.K., Shrestha, B.B., 2015. Facing north or south: Does slope aspect impact forest stand characteristics and soil properties in a semiarid trans-Himalyan valley? J. Arid. Environ. 121, 112-123.

Marquis, D.A., 1967. Clearcutting in northern hardwoods: Results after 30 years. Res. Pap. NE85, Upper Darby, PA: U.S. Department of Agriculture, Forest Service, Northeastern Forest Experiment Station. 1-13.

McGee, C.E., Hooper, R.M., 1975. Regeneration trends 10 years after clearcutting of an Appalachian hardwood stand. Research Note SE-RN-227, Asheville, NC: U.S. Department of Agriculture, Forest Service, Southeastern Forest Experiment Station. 1-4.

Meadows, J.S., 1995. Epicormic branches and lumber grade of bottomland oak. In: Lowery, G., Meyer, D., eds. Advances in hardwood utilization: following profitability from the woods through rough dimension: Proceedings of the twenty-third annual hardwood symposium. Memphis, TN: National Hardwood Lumber Association. 19-25.

Meadows, J.S., Burkhardt, E.C., 2001. Epicormic branches affect lumber grade and value in willow oak. South. J. Appl. For. 25, 136-141.

Meadows, J.S., Goelz, J.C.G., Skojac Jr., D.A., 2013. Influences of tree, stand, and site characteristics on the production of epicormic branches in southern bottomland hardwood forests. In: Guldin, J.M., ed. 2013. Proceedings of the $15^{\text {th }}$ biennial southern silvicultural research conference, e-Gen. Tech. Rep. SRS-GTR-175, Asheville, NC: U.S. Department of Agriculture, Forest Service, Southern Research Station. 47-55.

Meier, A.R., Saunders, M.R., Michler, C.H., 2012. Epicormic buds in trees: a review of bud establishment, development and dormancy release. Tree. Physiol. 32, 565-584.

Miller, G.W. Wood, P.B., Nichols, J.V., 1995. Two-age silviculture: an innovative tool for enhancing species diversity and vertical structure in Appalachian hardwoods. In: L.G. Eskew, comp. Forest health through silviculture: proceedings of the 1995 National 
Silviculture Workshop, Mescalero, New Mexico, May 8-11, 1995. Gen. Tech. Rep. RMGTR-267, Fort Collins, CO: U.S. Department of Agriculture, Forest Service, Rocky Mountain Forest and Range Experiment Station. 175-182.

Miller, G.W., 1996. Epicormic branching on central Appalachian hardwoods 10 years after deferment cutting. Res. Pap. NE-702, Radnor, PA: U.S. Department of Agriculture, Forest Service, Northeastern Forest Experiment Station. 1-9.

Miller, G.W., Hanks, L.F., Wiant, H.V., Jr., 1986. A key for the Forest Service hardwood tree grades. North J Appl. For. 3, 19-22.

Miller, G.W., Johnson, J.E., Baumgras, J.E., 1997a. Deferment cutting in central Appalachian hardwoods: an update. In: Proceedings of the $25^{\text {th }}$ annual hardwood symposium, nation hardwood lumber association, 1997 May 7-10, Cashiers, NC, Memphis, TN: National Hardwood Lumber Association. 83-97.

Miller, G.W., Johnson, J.E., Baumgras, J.E., Bustamente, R.G., 1997b. Two-age silviculture on the Monongahela National Forest- managers and scientists assess 17 years of communication. In: Communicating the role of silviculture in managing the national forests: Proceedings of the National Silviculture Workshop., 1997 May 19-22, Warren, PA. Gen. Tech. Rep. NE-238, Radnor, PA: U.S. Department of Agriculture, Forest Service, Northeastern Forest Experimental Station. 123-133.

Miller, G.W., Kochenderfer, J.N., Fekedulegn, D., 2004. Composition and development of reproduction in two-age Appalachian hardwood stands: 20-year results. In: Shepperd, W.D., Eskew, L.G., compilers, 2004. Silviculture in special places: Proceedings of the National Silviculture Workshop, 2003 Sept. 8-11, Granby, CO. Proceedings RMRS-P-34, Fort Collins, CO: U.S. Department of Agriculture, Forest Service, Rocky Mountain Research Station. 171-181.

Miller, G.W., Kochenderfer, J.N., Fekedulegn, D.B., 2006. Influence of individual reserve trees on nearby reproduction in two-aged Appalachian hardwood stands. Forest. Ecol. Mang. 224, 241-251.

Miller, G.W., Schuler, T.M., 1995. Development and quality of reproduction in two-age central Appalachian hardwoods- 10-year results. In: Gottschalk, K.W., Fosbroke, S.L.C., ed. Proceedings, $10^{\text {th }}$ Central Hardwood Forest Conference, 1995 March 5-8, Morgantown, WV. Gen. Tech. Rep. NE-197, Radnor, PA: U.S. Department of Agriculture, Forest Service, Northeastern Forest Experiment Station. 364-374.

Newsome, T.A., Heineman, J.L., Linnell Nemec, A.F., Comeau, P.G., Arsenault, A., Waterhouse, M., 2010. Ten-year regeneration responses to varying levels of overstory retention in two productive southern British Columbia ecosystems. Forest. Ecol. Mang. 260, 132-145. 
Nyland, R.D., 2005. Diameter-limit cutting and silviculture: A comparison of long-term yields and values for uneven-aged sugar maple stands. North. J. Appl. For. 22, 111-116.

O’Hara, K.L., Berrill, J.P., 2009. Epicormic sprout development in pruned coast redwood: pruning severity, genotype, and sprouting characteristics. Ann. For. Sci. 66, 409.

Olivero, A.M., Hix, D.M., 1998. Influence of aspect and stand age on ground flora of southeastern Ohio forest ecosystems. Plant. Ecol. 139, 177-187.

Palmer, J.F., 2008. The perceived scenic effects of clearcutting in the White Mountains of New Hampshire, USA. J. Environ. Manage. 89, 167-183.

Parker, G.R., Swank, W.T., 1982. Tree species response to clear-cutting a southern Appalachian watershed. Am. Midl. Nat. 108, 304-310.

Ribe, R.G., 2005. Aesthetic perceptions of green-tree retention harvests in vista views The interaction of cut level, retention pattern and harvest shape. Landscape. Urban. Plan. 73, 277-293.

Rodríguez-García, E., Juez, L., Bravo, F., 2010. Environmental influences on post-harvest natural regeneration of Pinus pinaster Ait. in Mediterranean forest stands submitted to the seed-tree selection method. Eur. J. Forest. Res. 129, 1119-1128.

Rosenfeld, J.M., Navarro Cerrillo, R.M., Guzman Alvarez, J.R., 2006. Regeneration of Nothofagus pumilio [Poepp. et Endl.] Krasser forests after five years of seed tree cutting. J. Environ. Manage. 78, 44-51.

SAS, Version 9.3. 2002-2010. SAS Institute Inc., Cary, NC.

Schuler, T.M., 2004. Fifty years of partial harvesting in a mixed mesophytic forest: composition and productivity. Can. J. For. Res. 34, 985-997.

Schuler, T.M., Marquis, D.A., Ernst, R.L, Simpson, B.T., 1993. Test of four stand growth simulators for the northeastern United States. Res. Pap. NE-676, Radnor, PA: U.S. Department of Agriculture, Forest Service, Northeastern Forest Experiment Station. 1-14.

Schuler, T.M., Miller, G.W., 1995. Shelterwood treatments fail to establish oak reproduction on mesic forest sites in West Virginia- 10-year results. In: Gottschalk, K.W., Fosbroke, S.L., ed. Proceedings, $10^{\text {th }}$ Central Hardwood Forest Conference, 1995 Merch 5-8, Morgantown, WV, Gen. Tech. Rep. NE-197, Radnor, PA: U.S. Department of Agriculture, Forest Service, Northeastern Forest Experiment Station. 375-387.

Schuler, T.M., Thomas-Van Gundy, M., Brown, J.P., Wiedenbeck, J.K., 2017. Managing Appalachian hardwood stands using four management practices: 60 -year results. Forest. Ecol. Mang. 387, 3-11. 
Smith, H.C., 1981. Diameters of clearcut openings influence central Appalachian hardwood stem development- a 10-year study. Res. Pap. NE-476, Broomall, PA: U.S. Department of Agriculture, Forest Service, Northeastern Forest Experiment Station. 1-8.

Smith, H.C., Lamson, N.I. Miller, G.W., 1989. An esthetic alternative to clearcutting? J. Forest. 87, 14-18.

Smith, H.C., Miller, G.W., 1991. Deferment cutting in Appalachian hardwoods: the what, whys, and hows. In: Johnson, J.E., ed. Uneven aged silviculture of upland hardwood stands workshop notes, 1991 February 25-27, Blacksburg, VA: Virginia Cooperative Extension Service and Virginia Polytechnic Institute and State University. 33-37.

Smith, H.C., Rosier, R.L., Hammack, K.P., 1976. Reproduction 12 years after seed-tree harvest cutting in Appalachian hardwoods. Res. Pap. NE-350, Upper Darby, PA: U.S. Department of Agriculture, Forest Service, Northeastern Forest Experiment Station. 1-11.

Soil Survey Staff, Natural Resources Conservation Service, U.S. Department of Agriculture. Web Soil Survey. https://websoilsurvey.sc.egov.usda.gov/. Accessed March 2019.

Stout, S., Thomasma, S. SILVAH, Version 7.0.3.6. Nov. 2018. Irvine, PA: U.S. Department of Agriculture, Forest Service, Northeastern Research Station.

Strong, T.F., Erdmann, G.G., 2000. Effects of residual stand density on growth and volume production in even-aged red maple stands. Can. J. For. Res. 30, 372-378.

Thomas-Van Gundy, M., Schuler, T.M., 2008. Deferred rotation harvests in central Appalachia: 20- and 25-year results. In: Jacobs, D.F., Michler, C.H., eds. 2008. Proceedings, $16^{\text {th }}$ Central Hardwood Forest Conference, 2008 April 8-9, West Lafayette, IN. Gen. Tech. Rep. NRS-P-24, Newtown Square, PA: U.S. Department of Agriculture, Forest Service, Northern Research Station. 423-435.

Troup, R.S., 1966. Silvicultural systems. Oxford, U.K.: Oxford Clarendon Press. 1-216.

U.S. Forest Service., 1976. Other Softwoods. Regional Appendix E, Tables and Charts.

Vickers, L.A., Fox, T., 2015. Species composition of developing Central Appalachian hardwood stands following clearcutting. In: Proceedings of the $17^{\text {th }}$ biennial southern silvicultural research conference. e-Gen. Tech. Rep. SRS-203, Asheville, NC: U.S. Department of Agriculture, Forest Service, Southern Research Station. 1-8.

Wendel, G.W., Trimble, G.R., Jr., 1968. Early reproduction after seed-tree harvest cuttings in Appalachian hardwoods. Res. Pap. NE-99, Upper Darby, PA: U.S. Department of Agriculture, Forest Service, Northeastern Forest Experiment Station. 1-16. 
Westfall, J.A., Lausten, K.M., 2006. A merchantable and total height model for tree species in Maine. North. J. Appl. For. 23, 241-249.

Wurtz, T.L., Zasada, J.C., 2001. An alternative to clear-cutting in the boreal forest of Alaska: a 27 -year study of regeneration after shelterwood harvesting. Can. J. For. Res. 31, 9991011.

WVU Appalachian Hardwood Center. 2014. WV Timber Market Report. http://ahc.caf.wvu.edu/ahc-resources-mainmenu-45/timber-market-report-mainmenu-62. Accessed March 2019. 


\section{TABLES AND FIGURES}

Table 1. Number of residual trees of each species with epicormic branches. Species abundance is described in total trees and trees with epicormic branches present.

\begin{tabular}{ccccc}
\hline & & \multicolumn{3}{c}{ Number of Trees } \\
\hline Species & $\begin{array}{c}\text { Dominant } \\
\text { Aspect }^{\mathbf{a}}\end{array}$ & Total & $\begin{array}{c}\text { Epicormic } \\
\text { Branches }\end{array}$ & $\begin{array}{c}\text { \% Epicormic } \\
\text { Branches }^{\mathbf{b}}\end{array}$ \\
\hline Black Oak & South & 17 & 17 & $100 \%$ \\
Chestnut Oak & South \& East & 65 & 59 & $90.8 \%$ \\
Hickory & East & 25 & 20 & $80.0 \%$ \\
Northern Red Oak & South & 7 & 5 & $71.4 \%$ \\
Red Maple & South & 20 & 20 & $100 \%$ \\
Sugar Maple & East & 21 & 17 & $81.0 \%$ \\
White Oak & East & 16 & 16 & $100 \%$ \\
Yellow-poplar & East & 16 & 13 & $81.3 \%$ \\
\hline
\end{tabular}

${ }^{a}$ Dominance defined by the amount of basal area each species occupied and which aspect the species is more prominent on.

${ }^{b}$ Percentages indicate the proportion out of the total residual trees inventoried.

Table 2. Number of residual trees with epicormic branches for each tree grade. Species abundance is described in total trees and trees with epicormic branches present.

\begin{tabular}{cccccc}
\hline \multirow{2}{*}{ Group } & Tree & & & & \\
Grade & \multicolumn{2}{c}{ Total Trees } & \multicolumn{2}{c}{ Epicormic Branches } \\
\cline { 3 - 6 } All Trees & 1 & 142 & $(71.4 \%)^{\mathrm{a}}$ & $61(64.2 \%)$ & $59(72.8 \%)$ \\
& $2 \& 3$ & 57 & $(28.6 \%)$ & $34(35.8 \%)$ & $22(27.2 \%)$ \\
\cline { 2 - 6 } & Total & $\mathbf{1 9 9}$ & & $\mathbf{9 5}$ & $\mathbf{8 1}$ \\
\hline $\begin{array}{c}\text { Merchantable } \\
\text { Trees }\end{array}$ & 1 & 127 & $(76.0 \%)$ & $54(67.5 \%)$ & $52(80.0 \%)$ \\
& $2 \& 3$ & 40 & $(24.0 \%)$ & $26(32.5 \%)$ & $13(20.0 \%)$ \\
\cline { 2 - 6 } & Total & $\mathbf{1 6 7}$ & & $\mathbf{8 0}$ & $\mathbf{6 5}$ \\
\hline
\end{tabular}

${ }^{\mathrm{a}}$ Percentages in parentheses indicate the proportion out of the total residual trees inventoried. 
Table 3. Present lumber value per acre of each species on each aspect in 2018.

\begin{tabular}{ccc}
\hline & \multicolumn{2}{c}{ Total Lumber Value (\$/acre) } \\
\hline Species & South & East \\
\hline Black Oak & 279 & 100 \\
Chestnut Oak & 728 & 442 \\
Hickory & 8 & 260 \\
Northern Red Oak & 150 & 63 \\
Red Maple & 157 & 53 \\
Sugar Maple & 44 & 278 \\
White Oak & 154 & 240 \\
Yellow-poplar & 23 & 178 \\
Other Species $^{\mathrm{a}}$ & $53^{\mathrm{b}}$ & 54 \\
\hline Total & $\mathbf{1 , 5 9 6}$ & $\mathbf{1 , 6 6 8}$ \\
\hline
\end{tabular}

${ }^{\mathrm{a}}$ Species include American beech, birch, basswood (Tilia americana), blackgum, eastern hemlock, sassafras

${ }^{\mathrm{b}}$ Value includes scarlet oak (Quercus coccinea), which was only present on the south aspect.

Table 4. Number of residual merchantable trees downgraded in tree grade due to the presence of epicormic branches on the south and east aspects.

\begin{tabular}{|c|c|c|c|c|c|}
\hline \multirow[t]{2}{*}{ Aspect } & \multirow[t]{2}{*}{$\begin{array}{c}\text { Presumed } \\
\text { Grade }^{\mathrm{a}}\end{array}$} & \multicolumn{3}{|c|}{$\begin{array}{c}\text { Observed } \\
\text { Grade }^{\text {b }}\end{array}$} & \multirow[t]{2}{*}{ Total } \\
\hline & & 1 & 2 & 3 & \\
\hline \multirow[t]{3}{*}{ South } & 1 & 61 & 5 & 1 & 67 \\
\hline & $2 \& 3$ & --- & 15 & 6 & 21 \\
\hline & Total & 61 & 20 & 7 & 88 \\
\hline \multirow[t]{3}{*}{ East } & 1 & 66 & 3 & 0 & 69 \\
\hline & $2 \& 3$ & --- & 8 & 2 & 10 \\
\hline & Total & 66 & 11 & 2 & 79 \\
\hline
\end{tabular}

${ }^{\mathrm{a}}$ Grade given to tree without the effect of epicormic branches.

${ }^{b}$ Grade given to a tree with effect of epicormic branches at time of inventory. 
Table 5. Total number of commercial and non-commercial species present in the regeneration cohort four years after deferment harvest.

\begin{tabular}{rccc}
\hline \multicolumn{4}{c}{ Number of Species } \\
\hline Aspect & Commercial $^{\text {a }}$ & Non-commercial & Total \\
\hline South & 14 & 10 & 24 \\
East & 13 & 20 & 33 \\
\hline
\end{tabular}

a Species was classified as commercial if it was known to be retrieved for timber production

Table 6. Species richness in each aspect by shade tolerance class.

\begin{tabular}{rcc}
\hline & \multicolumn{2}{c}{ Aspect } \\
\hline Shade-Tolerance & South & East \\
\hline Intolerant & $7(4)^{\mathrm{a}}$ & $8(3)$ \\
Mid-tolerant & $7(6)$ & $10(6)$ \\
Tolerant & $10(4)$ & $15(4)$ \\
\hline
\end{tabular}

${ }^{\mathrm{a}}$ Number in parentheses is the number of commercial species. 
Table 7A. Species of the regeneration cohort by dominant height on the south aspect. Dominant height is written as average \pm standard error.

\begin{tabular}{|c|c|c|c|c|c|}
\hline \multirow{2}{*}{$\begin{array}{l}\text { Species } \\
\text { Ailanthus }\end{array}$} & \multirow[t]{2}{*}{ Commercial } & \multirow{2}{*}{$\begin{array}{c}\begin{array}{c}\text { Dominant } \\
\text { Average Stems } \\
\text { per acre }\end{array} \\
18.5\end{array}$} & \multicolumn{2}{|c|}{$\begin{array}{c}\text { Number of } \\
\text { Plots }^{\mathrm{a}}\end{array}$} & \multirow{2}{*}{$\begin{array}{c}\text { Dominant Height }(\mathbf{f t}) \\
\text { (Average } \pm \text { SE) }\end{array}$} \\
\hline & & & 3 & $3 \%^{b}$ & \\
\hline American Beech & $X$ & 120.4 & 25 & $23 \%$ & $6.7 \pm 0.1$ \\
\hline American Chestnut & & 18.5 & 3 & $3 \%$ & $11.0 \pm 1.0$ \\
\hline Birch & $X$ & 351.9 & 40 & $37 \%$ & $5.7 \pm 0.3$ \\
\hline Black Cherry & $X$ & 27.8 & 8 & $7 \%$ & $4.8 \pm 1.7$ \\
\hline Black Oak & $X$ & 18.5 & 28 & $26 \%$ & $6.6 \pm 0.3$ \\
\hline Blackgum & & 370.4 & 48 & $44 \%$ & $3.4 \pm 0.9$ \\
\hline Chestnut Oak & $X$ & 185.2 & 57 & $53 \%$ & $7.4 \pm 1.0$ \\
\hline Cucumbertree & $X$ & 37.0 & 7 & $6 \%$ & $4.8 \pm 0.4$ \\
\hline Hickory & $X$ & 55.6 & 17 & $16 \%$ & $5.3 \pm 0.7$ \\
\hline Northern Red Oak & $X$ & 175.9 & 54 & $50 \%$ & $5.1 \pm 0.5$ \\
\hline PawPaw & & 27.8 & 4 & $4 \%$ & $12.7 \pm 1.0$ \\
\hline Red Maple & $X$ & 666.7 & 85 & $79 \%$ & $8.8 \pm 0.4$ \\
\hline Sassafras & & 333.3 & 72 & $67 \%$ & $4.4 \pm 0.3$ \\
\hline Scarlet Oak & $\mathrm{X}$ & 9.3 & 3 & $3 \%$ & $2.1 \pm 0.0^{\mathrm{c}}$ \\
\hline Sourwood & & 435.2 & 30 & $28 \%$ & $2.9 \pm 0.4$ \\
\hline Sumac & & 18.5 & 5 & $5 \%$ & $9.4 \pm 0.4$ \\
\hline White Oak & $X$ & 46.3 & 13 & $12 \%$ & $7.6 \pm 1.9$ \\
\hline Yellow-poplar & $X$ & 83.3 & 50 & $46 \%$ & $5.3 \pm 1.3$ \\
\hline
\end{tabular}

${ }^{\mathrm{a}}$ Number of plots with each species comprising of dominant stems.

${ }^{\mathrm{b}}$ Proportion out of $\mathrm{N}=108$ total regeneration plots.

${ }^{\mathrm{c}}$ Proportion $\mathrm{SE}=0$ when species had only one dominant stem. 
Table 7B. Species of the regeneration cohort by dominant height on the east aspect. Dominant height is written as average \pm standard error.

\begin{tabular}{|c|c|c|c|c|c|}
\hline \multirow{2}{*}{$\begin{array}{l}\text { Species } \\
\text { Ailanthus }\end{array}$} & \multirow[t]{2}{*}{ Commercial } & \multirow{2}{*}{$\begin{array}{c}\begin{array}{c}\text { Dominant } \\
\text { Average Stems } \\
\text { per acre }\end{array} \\
120.4 \\
\end{array}$} & \multicolumn{2}{|c|}{$\begin{array}{c}\text { Number of } \\
\text { Plots }^{\mathrm{a}}\end{array}$} & \multirow{2}{*}{$\begin{array}{c}\text { Dominant Height }(\mathbf{f t}) \\
\text { (Average } \pm \text { SE) }\end{array}$} \\
\hline & & & 24 & $22 \%^{\mathrm{b}}$ & \\
\hline American Beech & $X$ & 74.1 & 19 & $18 \%$ & $5.8 \pm 0.4$ \\
\hline American Chestnut & & 9.3 & 2 & $2 \%$ & $7.8 \pm 0.0^{\mathrm{c}}$ \\
\hline Ash & $X$ & 83.3 & 29 & $27 \%$ & $6.0 \pm 0.9$ \\
\hline Birch & $X$ & 388.9 & 39 & $36 \%$ & $7.4 \pm 0.6$ \\
\hline Black Cherry & $X$ & 55.6 & 16 & $15 \%$ & $8.6 \pm 1.9$ \\
\hline Black Oak & $X$ & 9.3 & 13 & $12 \%$ & $9.7 \pm 0.0$ \\
\hline Blackgum & & 148.1 & 31 & $29 \%$ & $5.6 \pm 0.3$ \\
\hline Chestnut Oak & $\mathrm{X}$ & 83.3 & 27 & $25 \%$ & $6.8 \pm 1.6$ \\
\hline Cucumbertree & $X$ & 9.3 & 15 & $14 \%$ & $3.2 \pm 0.0$ \\
\hline Dogwood & & 27.8 & 4 & $4 \%$ & $6.0 \pm 1.6$ \\
\hline Eastern Hemlock & & 9.3 & 2 & $2 \%$ & $10.9 \pm 0.0$ \\
\hline Hickory & $X$ & 9.3 & 25 & $23 \%$ & $11.2 \pm 0.0$ \\
\hline Hophornbeam & & 46.3 & 2 & $2 \%$ & $12.7 \pm 1.5$ \\
\hline Northern Red Oak & $X$ & 120.4 & 32 & $30 \%$ & $6.9 \pm 0.8$ \\
\hline PawPaw & & 46.3 & 3 & $3 \%$ & $5.6 \pm 0.8$ \\
\hline Red Elm & & 9.3 & 2 & $2 \%$ & $6.2 \pm 0.0$ \\
\hline Red Maple & $X$ & 213.0 & 68 & $63 \%$ & $7.5 \pm 0.8$ \\
\hline Redbud & & 314.8 & 31 & $29 \%$ & $8.8 \pm 0.5$ \\
\hline Sassafras & & 101.9 & 28 & $26 \%$ & $4.5 \pm 0.7$ \\
\hline Sourwood & & 37.0 & 4 & $4 \%$ & $10.7 \pm 1.1$ \\
\hline Spice Bush & & 166.7 & 20 & $19 \%$ & $6.6 \pm 0.3$ \\
\hline Sugar Maple & $X$ & 388.9 & 61 & $56 \%$ & $7.9 \pm 0.5$ \\
\hline Sumac & & 111.1 & 16 & $15 \%$ & $6.0 \pm 0.7$ \\
\hline American Sycamore & & 27.8 & 1 & $1 \%$ & $3.1 \pm 0.2$ \\
\hline White Oak & $X$ & 9.3 & 23 & $21 \%$ & $3.5 \pm 0.0$ \\
\hline Witch Hazel & & 27.8 & 3 & $3 \%$ & $5.3 \pm 0.9$ \\
\hline Yellow-poplar & $X$ & 388.9 & 78 & $72 \%$ & $4.4 \pm 0.3$ \\
\hline
\end{tabular}




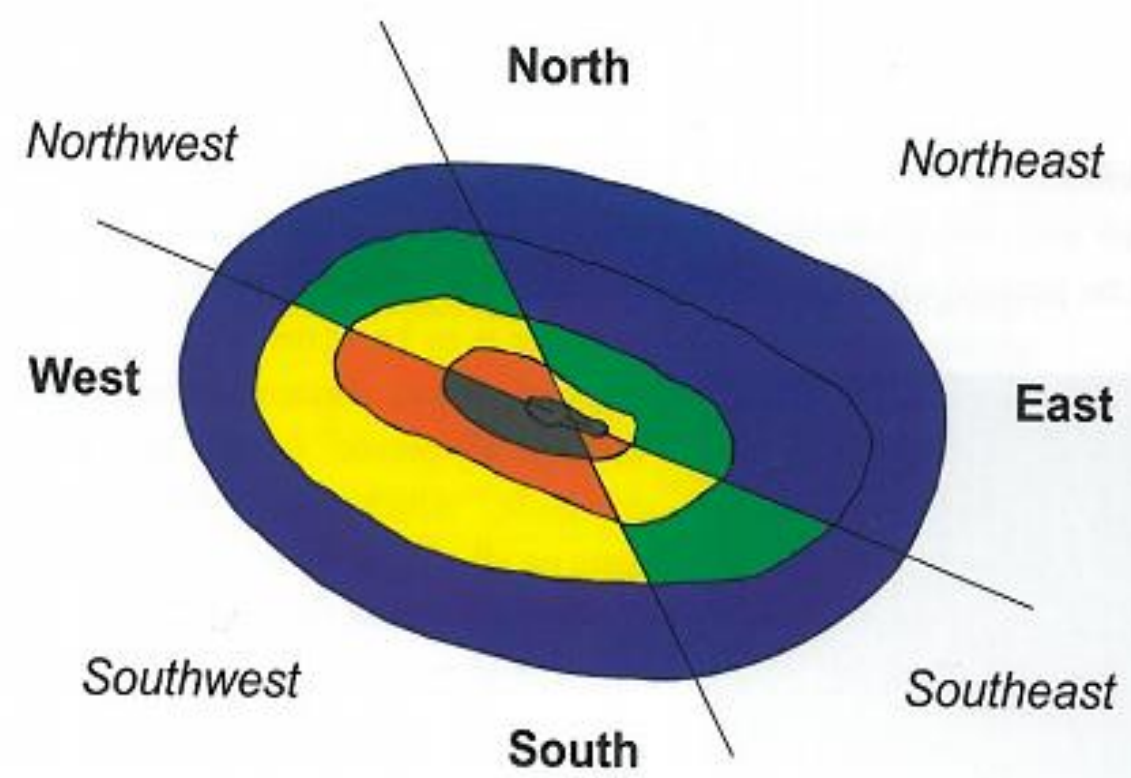

$\square 1$ - Hydric/Moist Mesic

2 - Mesic

$\square 3$ - Dry Mesic

4 - Dry

5 - Xeric

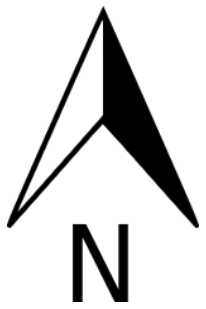

Figure 1. Diagram of aspect slopes and their corresponding moisture contents. Adapted from Carvell and Perkey (1997). 


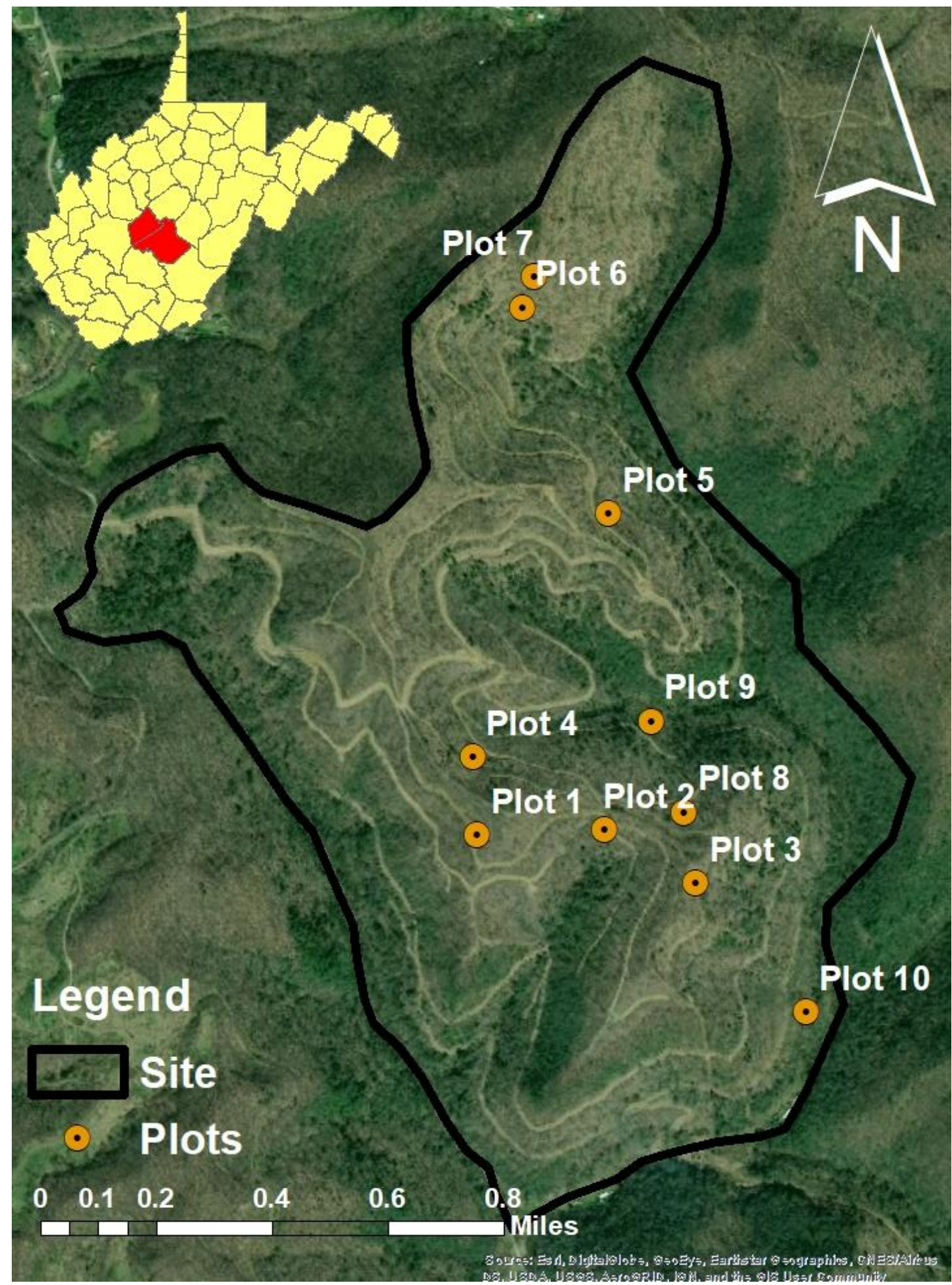

Figure 2. Map of study site with the ten permanent plots established by the consulting forester. These plots were established immediately after harvest and randomly throughout the site to monitor growth and timber production over time until next intended harvest in 25 years. 


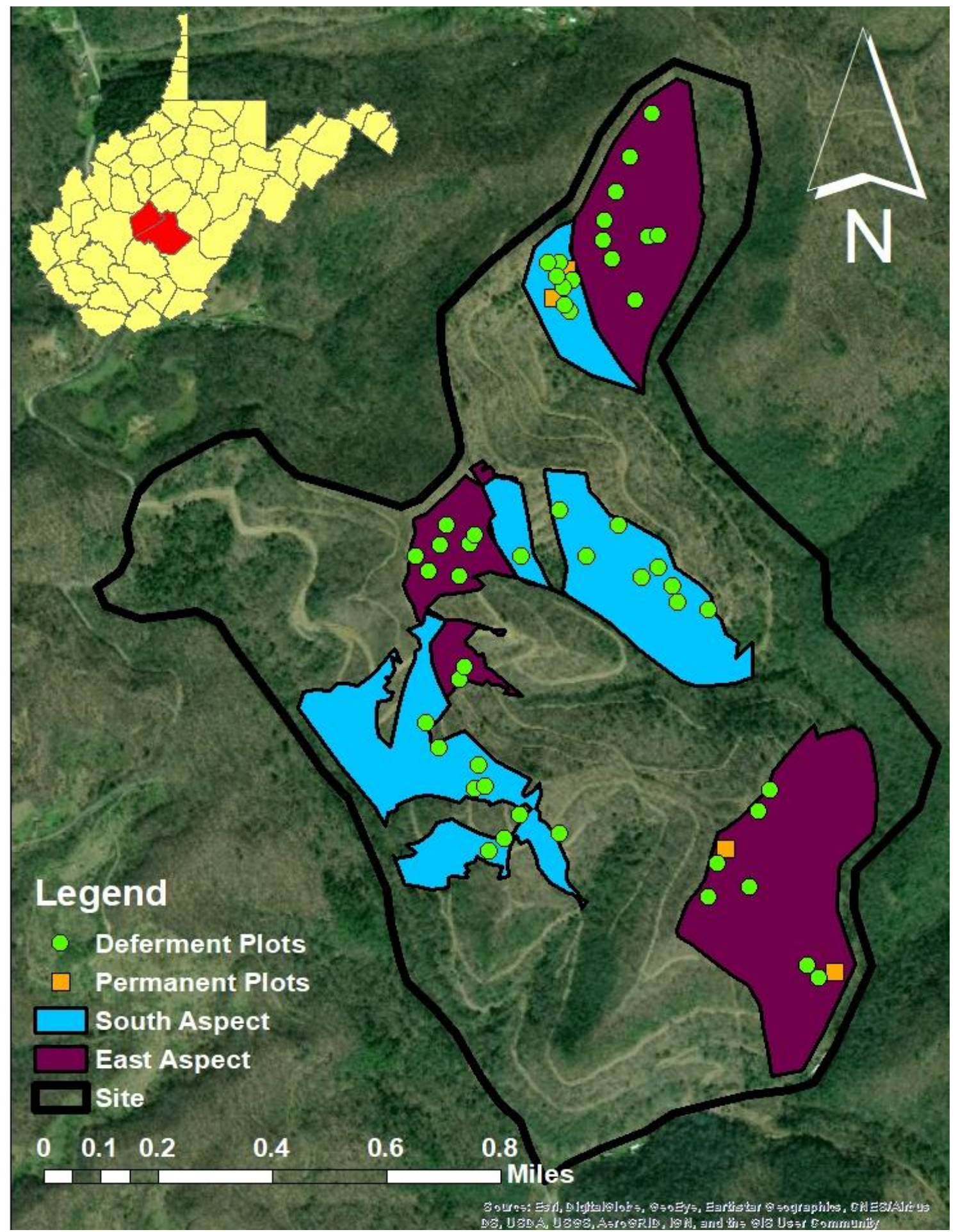

Figure 3. Map of study site with the nine residual plot points constructed in each aspect replicate. Four of the permanent plots established by the consulting forester were included in the residual plot sample, with two plots in one south replicate and two plots in one east replicate. 


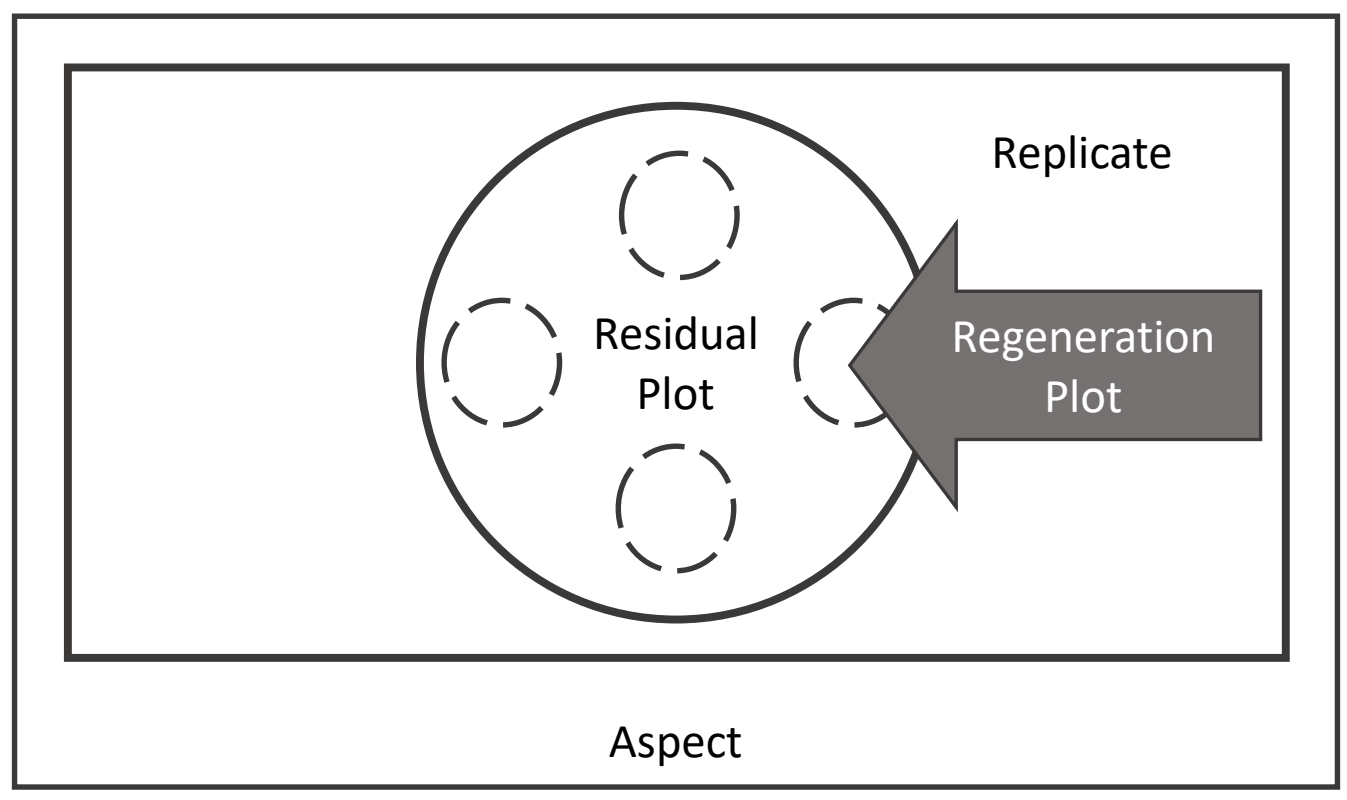

Figure 4. Conceptual layout of experimental design. Nine residual plots were nested within each of the six aspect replicates (three on the south aspect, three on the east aspect), with four regeneration plots nested within each residual plot. 


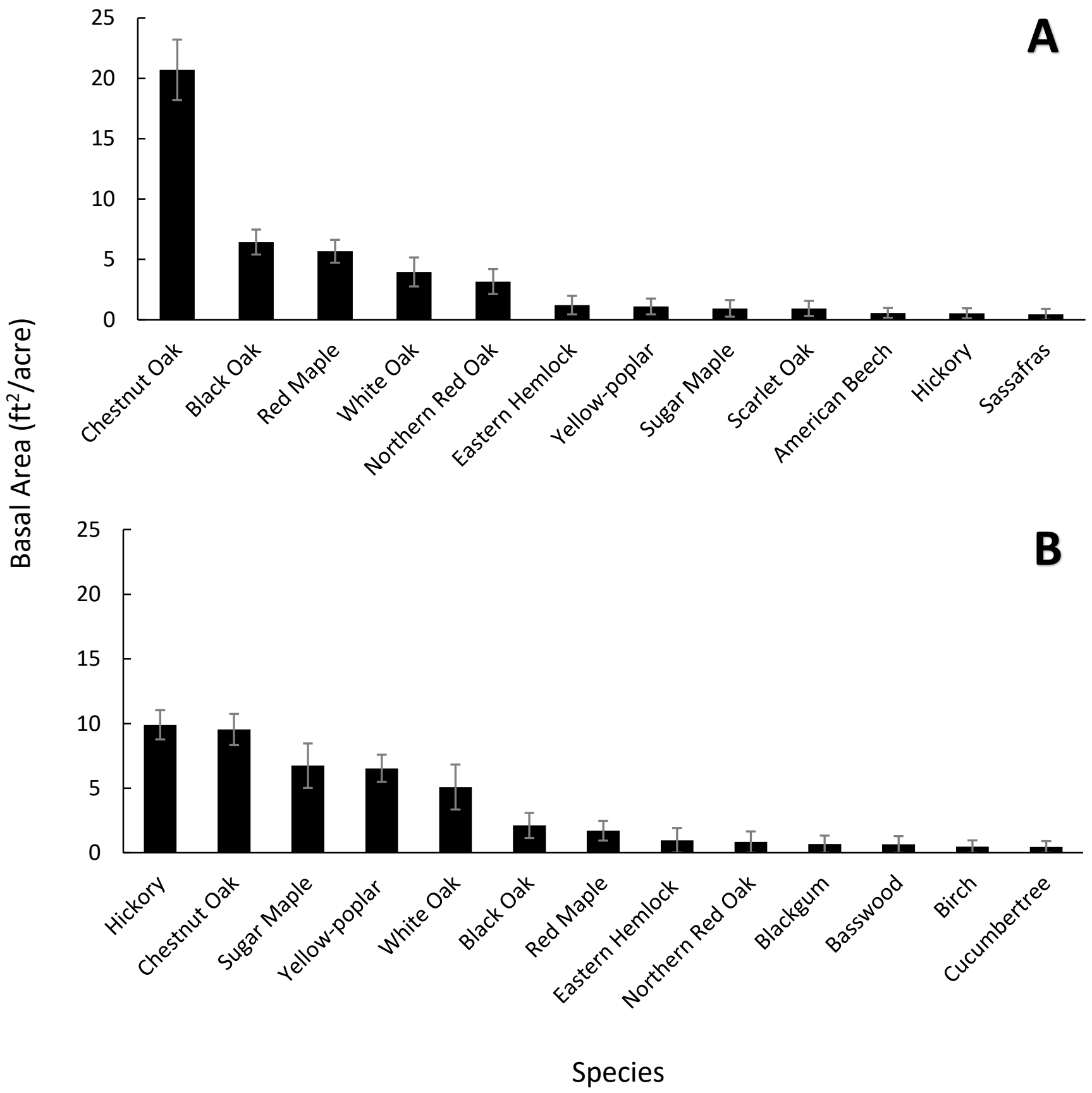

Figure 5. Average square feet basal area per acre of each species in the residual cohort on the A) south and B) east aspects. Error bars represent average \pm standard error. 


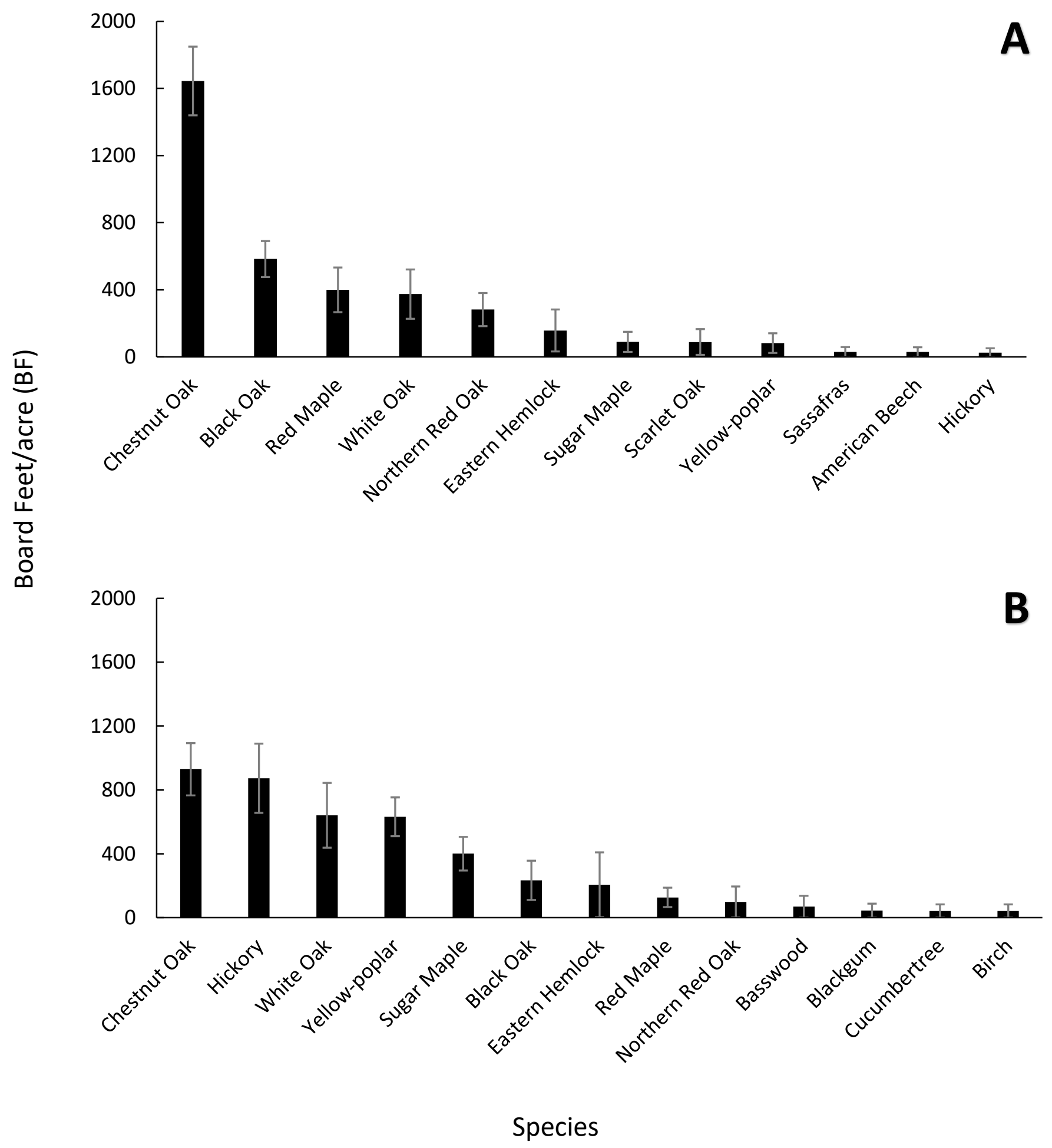

Figure 6. Average board feet per acre of volume of each species in the residual cohort on the A) south and B) east aspects. Error bars represent average \pm standard error. 


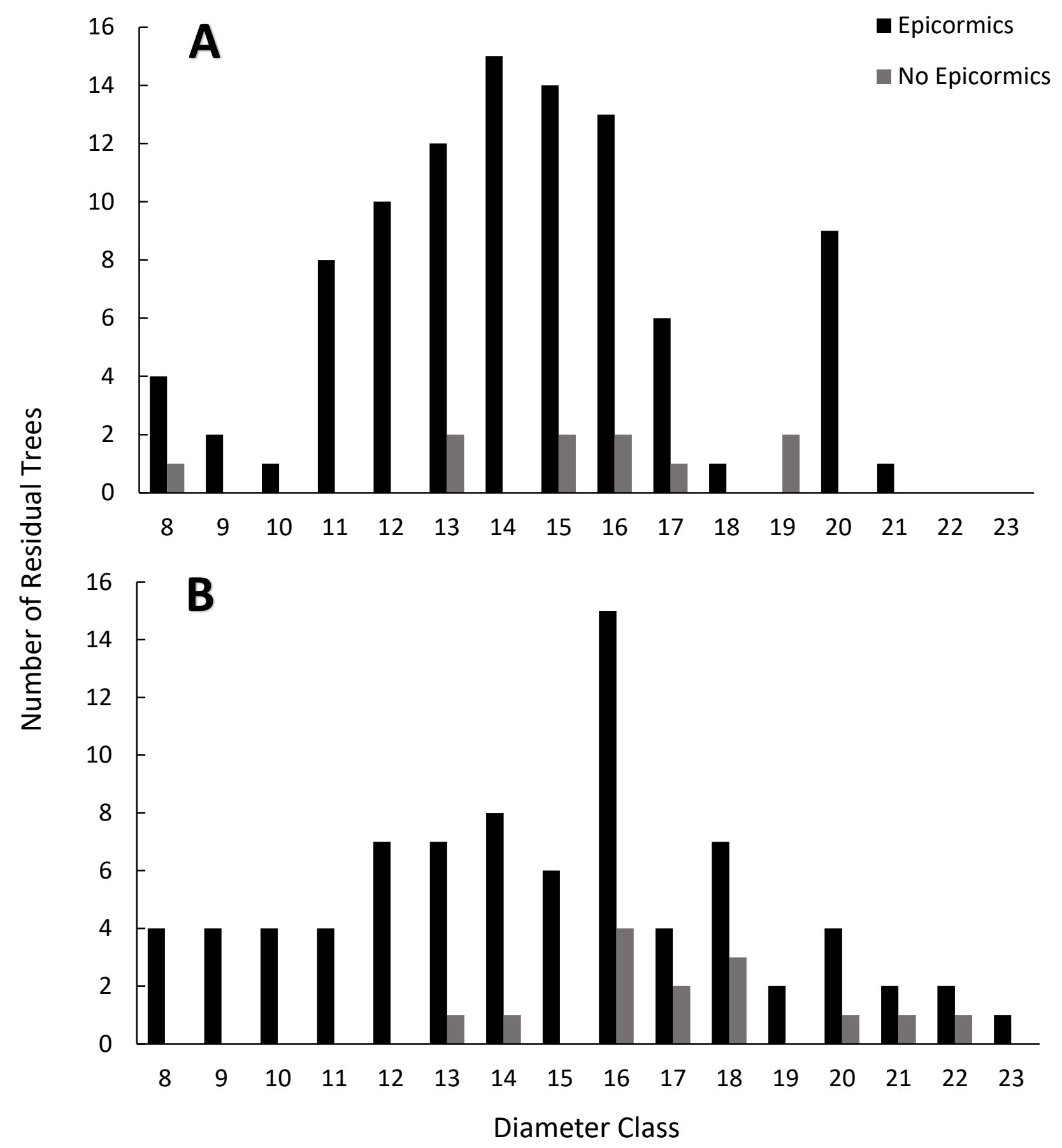

Figure 7. Number of residual trees with and without epicormic branches on the A) south and B) east aspects. 


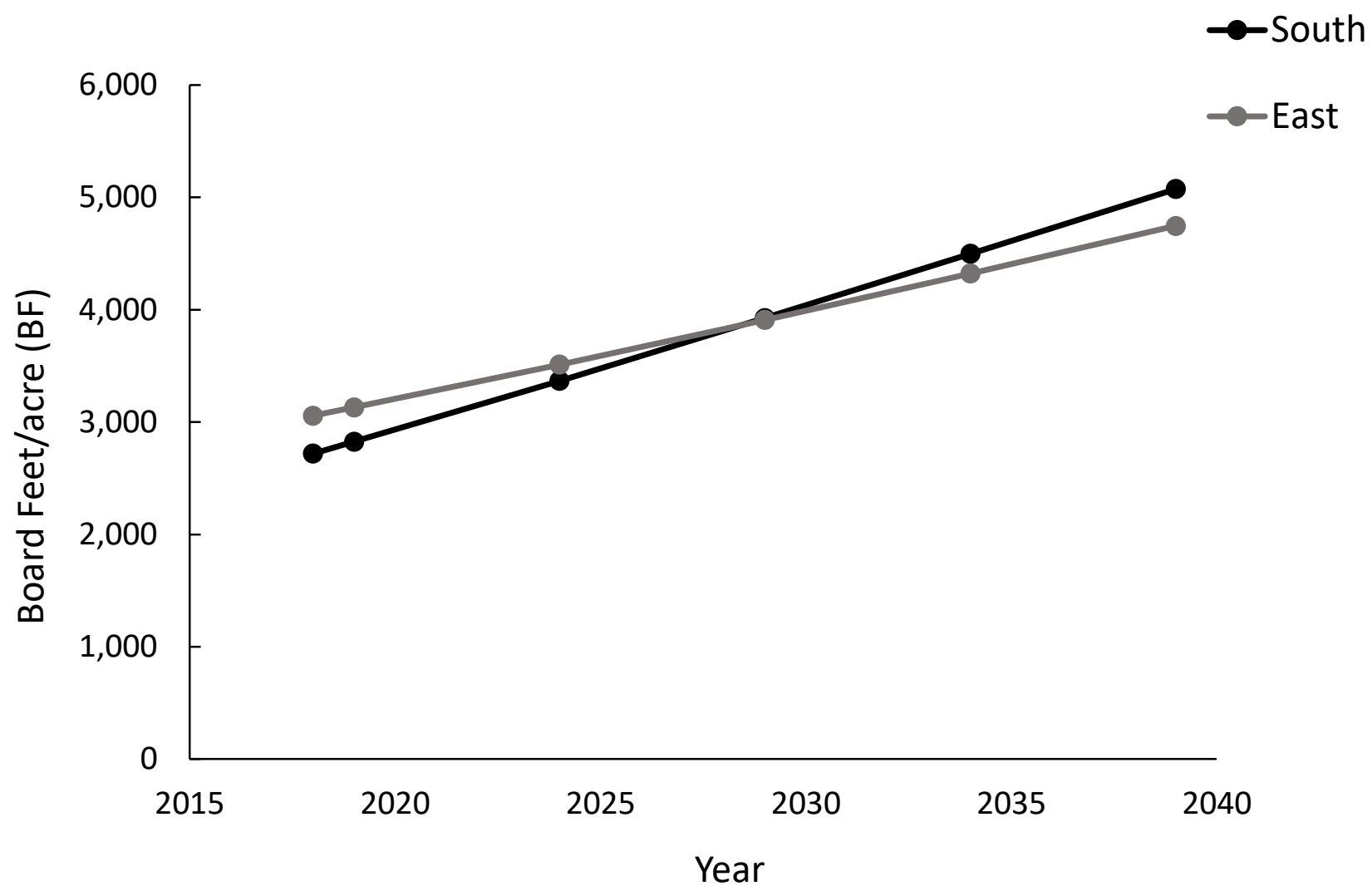

Figure 8. Total volume production $(\mathrm{BF})$ per acre on the south and east aspects over 25 years. Volume is expected to increase as it is dependent on the increase in DBH and merchantable height of each tree over time. Statistical t-test indicated no difference in volume production between the two aspects $(P>0.05)$. 


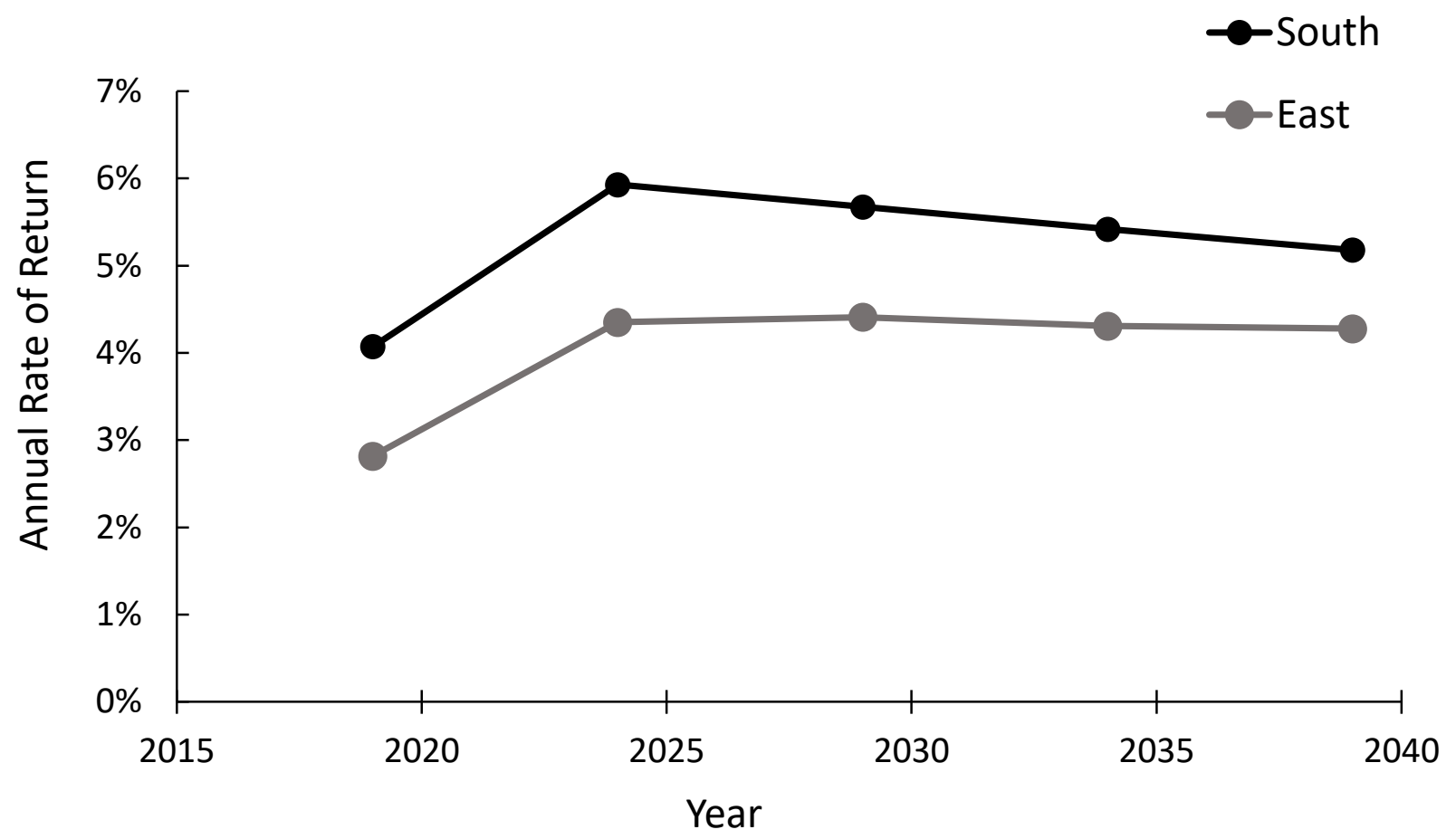

Figure 9. Annual rate of return on the total present value per acre up to 25 years after harvest. 


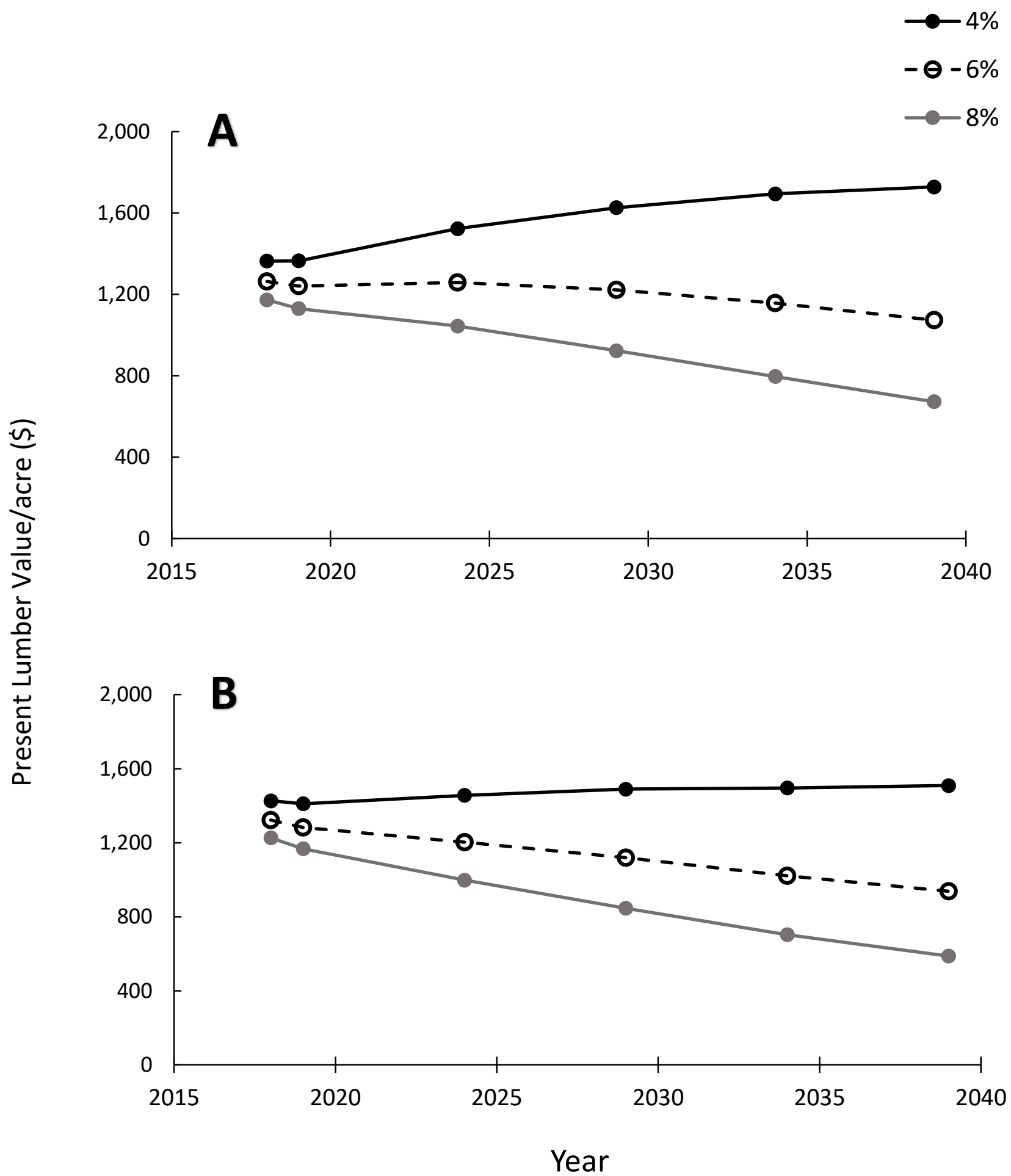

Figure 10. Present lumber value per acre over 25 years at $4 \%, 6 \%$, and $8 \%$ rates of return on the A) south and B) east aspects. 


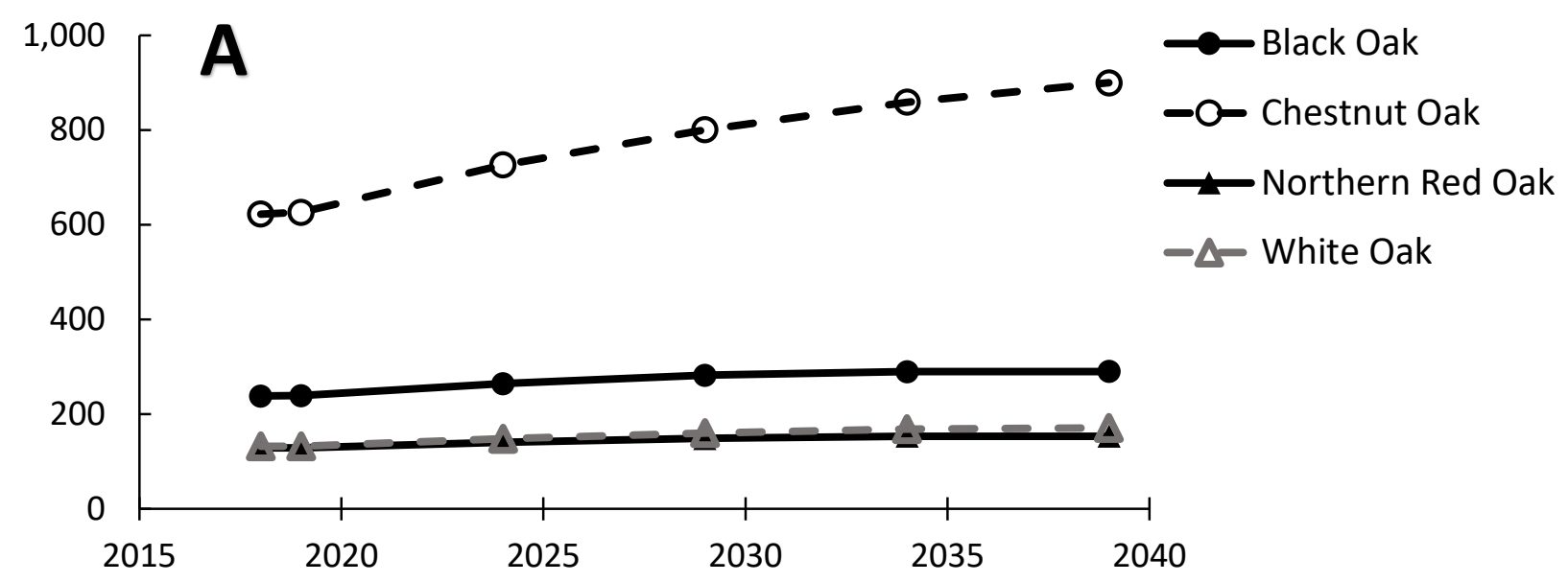

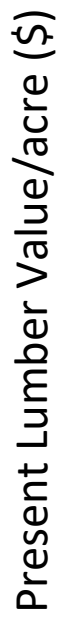
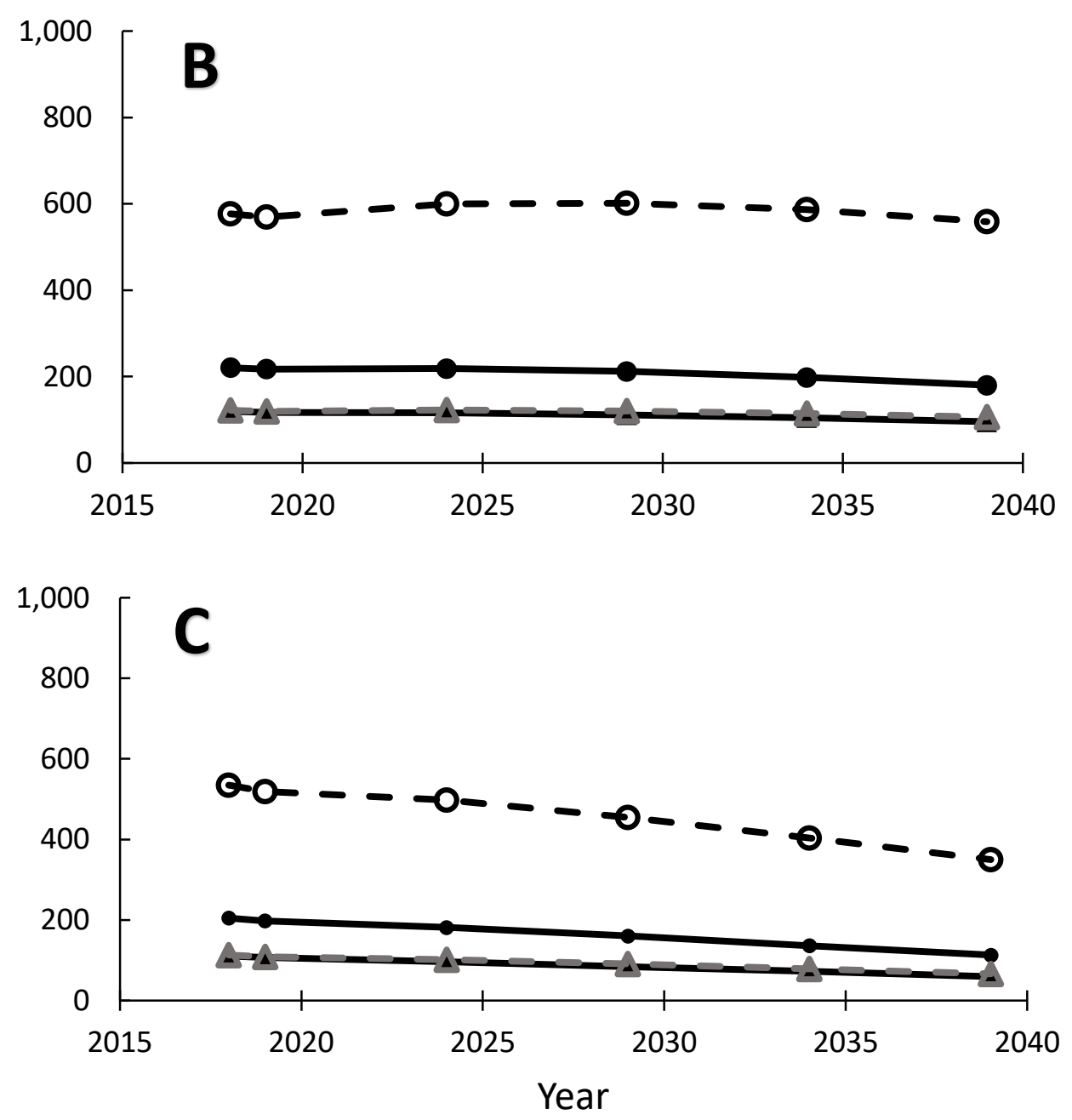

Figure 11. Present lumber value per acre of oak species on the south aspect at A) $4 \%$, B) $6 \%$, and C) $8 \%$ rates of return. 


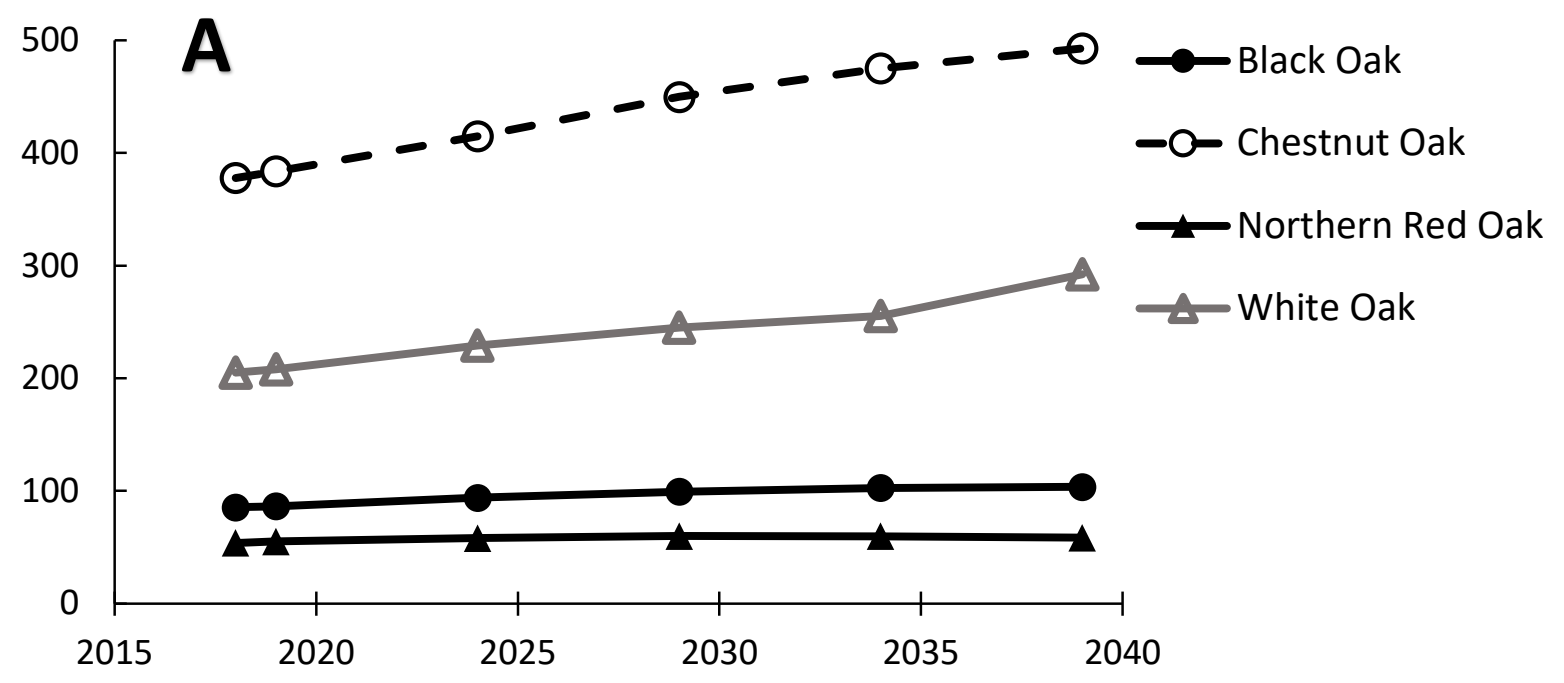

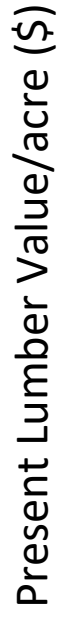
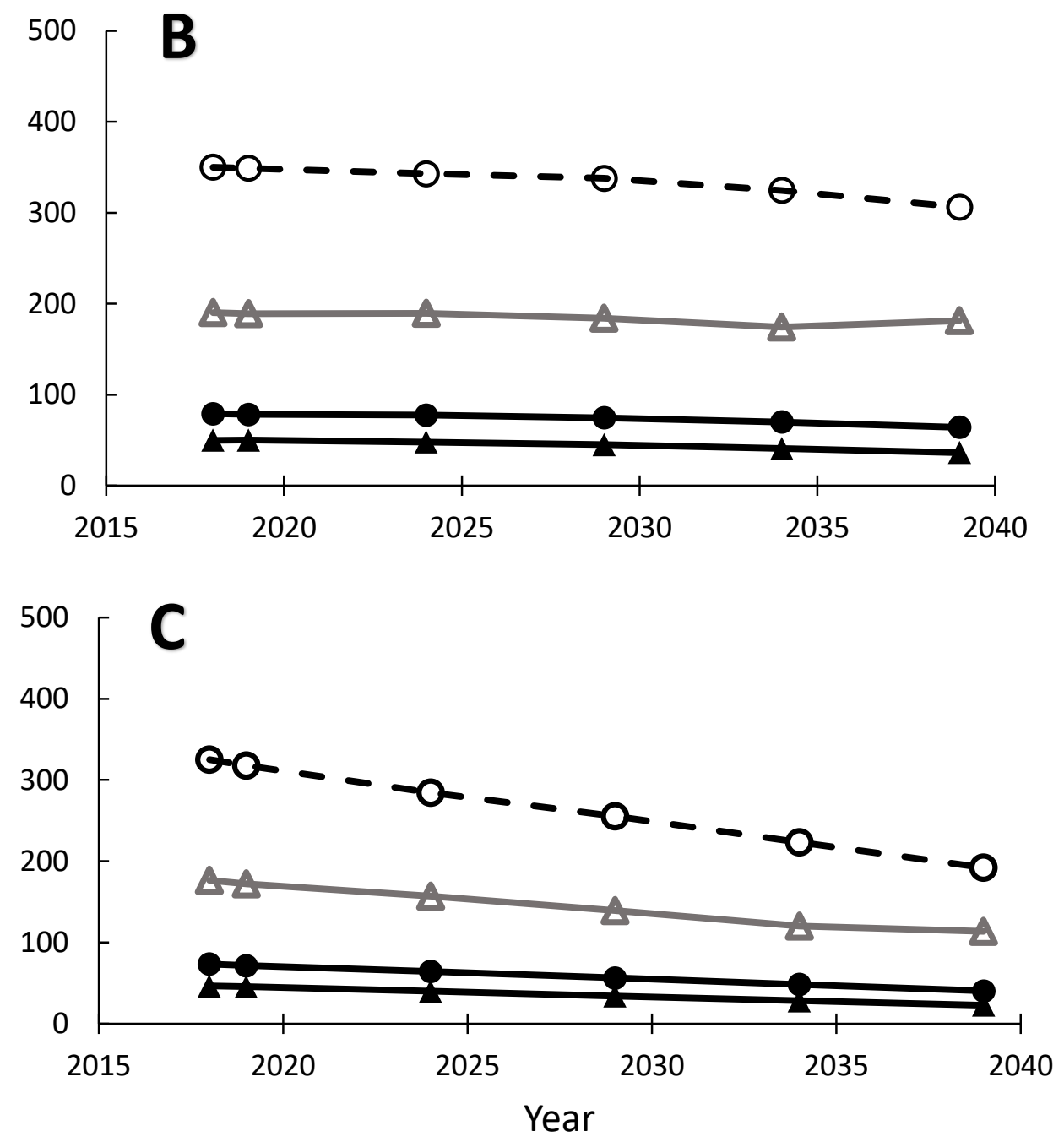

Figure 12. Present lumber value per acre of oak species on the east aspect at A) $4 \%$, B) $6 \%$, and C) $8 \%$ rates of return. 


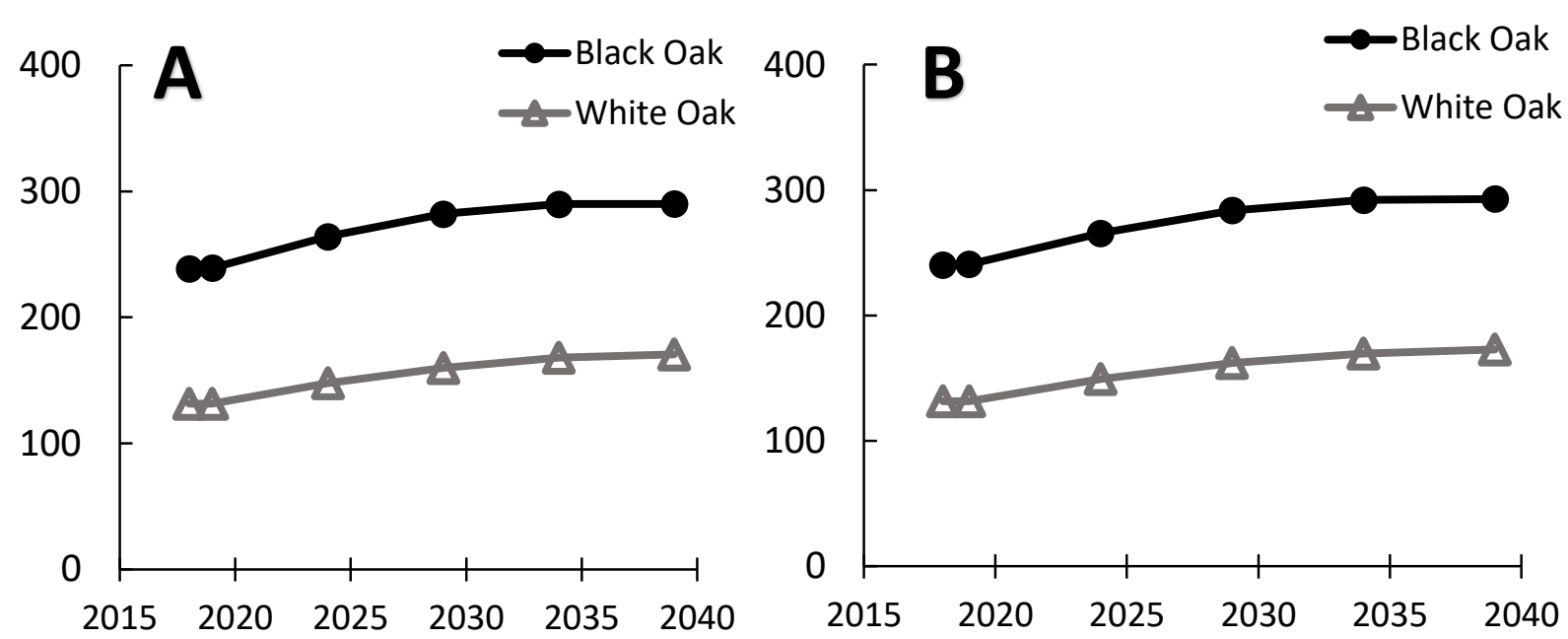

Year

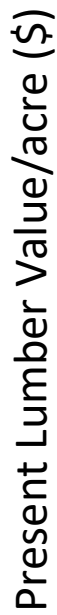
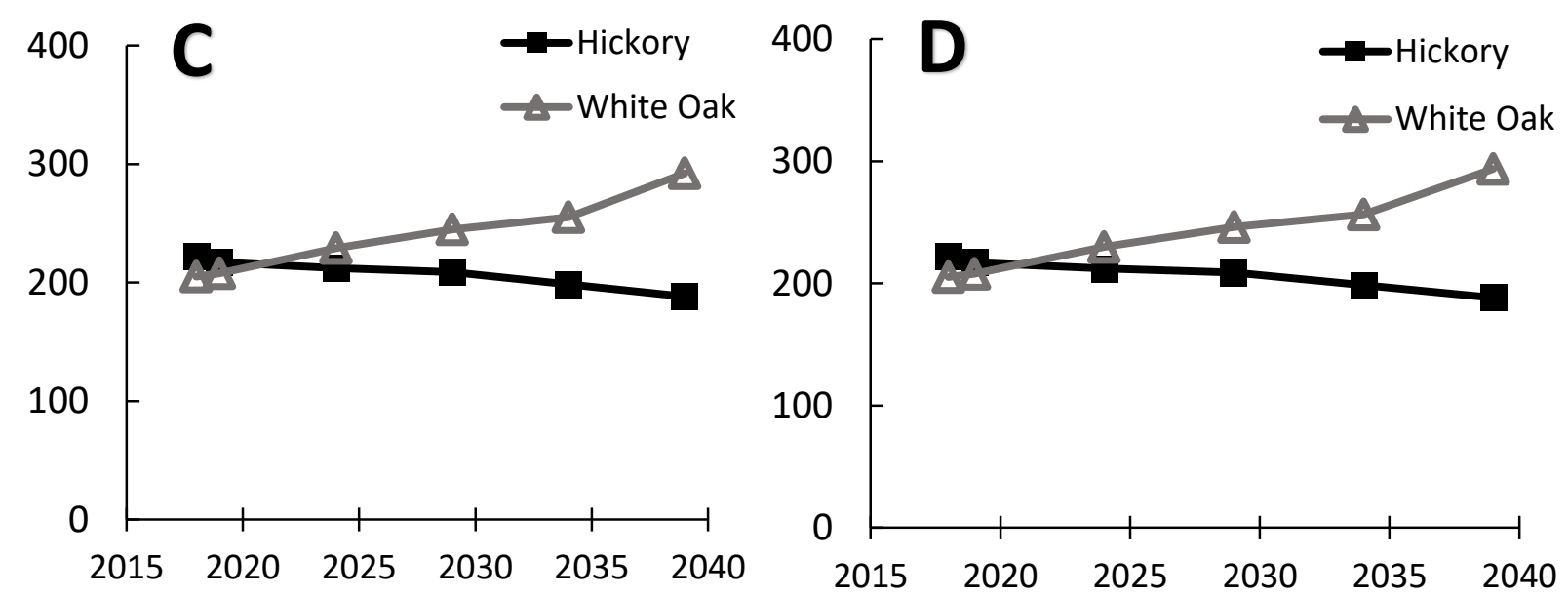

\section{Year}

Figure 13. Downgraded and potential present lumber values per acre of each species that were downgraded in quality due to the presence of epicormic branches on the A-B) south aspect and the C-D) east aspect. Downgraded values are the values of each species in their condition at time of inventory in 2018 with the effect of epicormic branches (A \& C). The potential values are the values if trees of these species were not affected by epicormic branches (B \& D). Projections are the present lumber values at $4 \%$ rate of return over 25 years. 


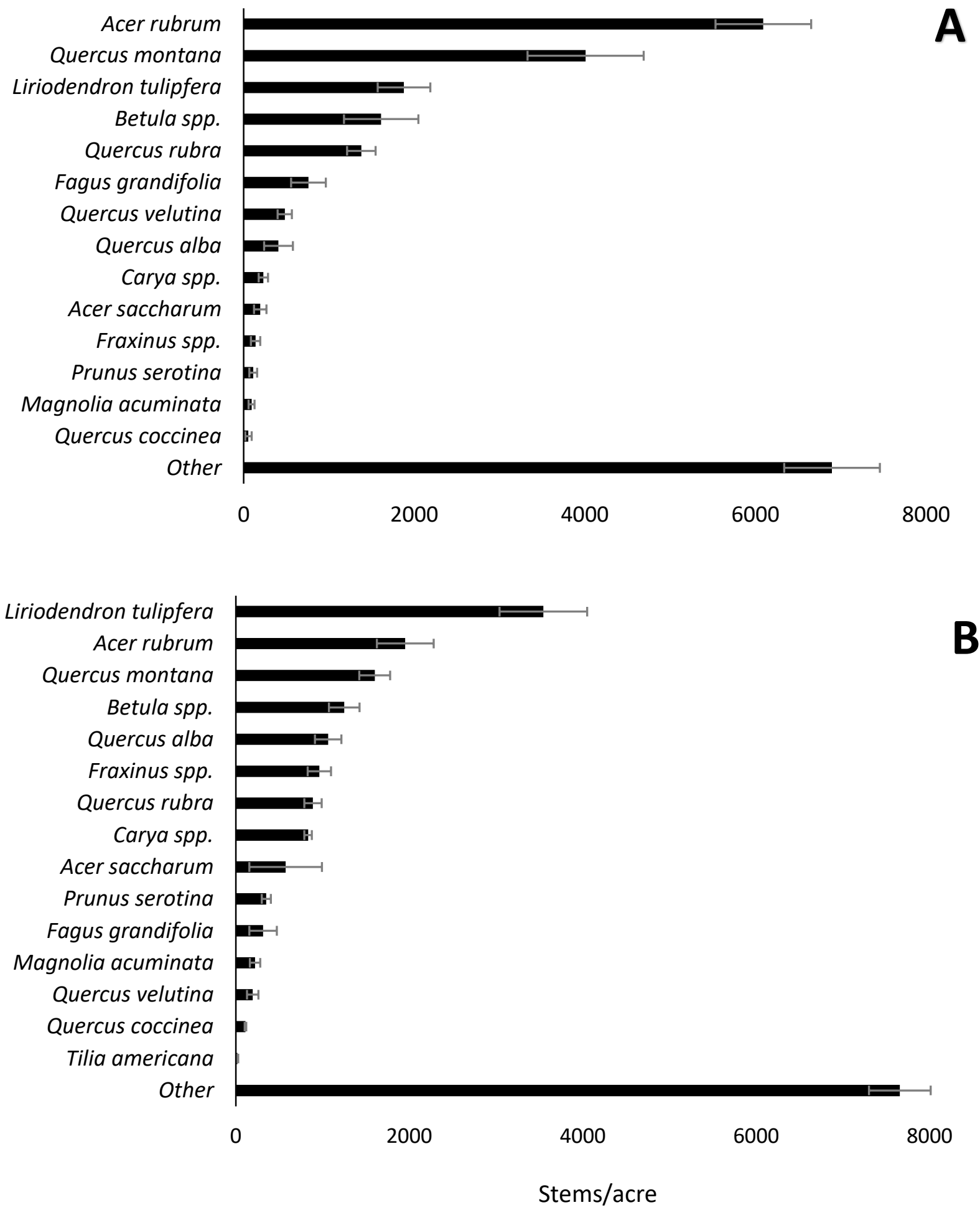

Figure 14. Species distribution in average stems per acre of regeneration stems at least 0.5 feet tall and less than one inch DBH on A) south and B) east aspects. Error bars represent average \pm standard error. 

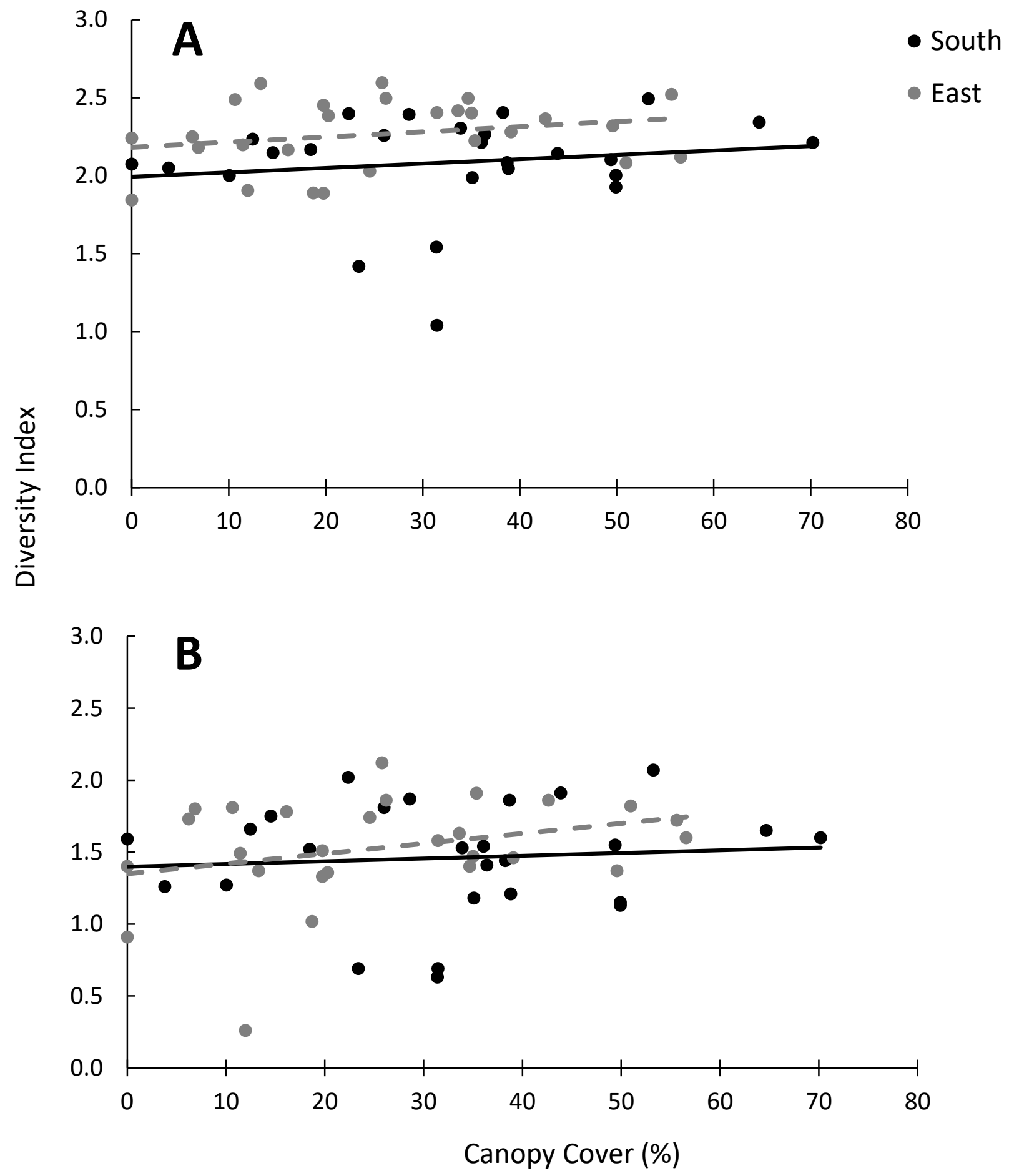

Figure 15. Species diversity as a function of canopy cover from the residual cohort of A) total regeneration species and B) only the commercial species. Original values are displayed here, while analysis required the use of cube transformation values for species diversity. 


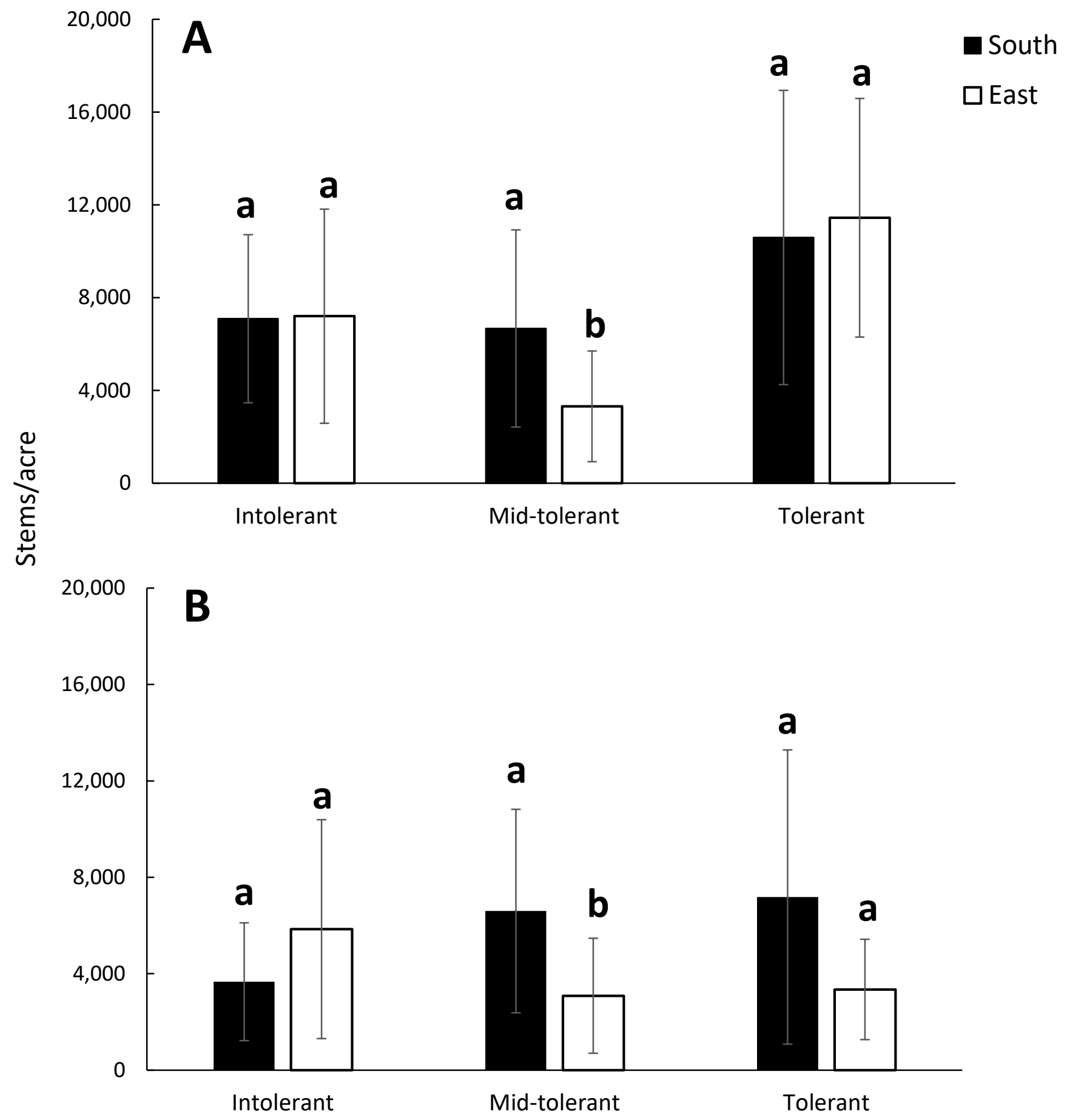

Figure 16. Average stems per acre on the south and east aspects by shade tolerance class for both A) total and B) commercial species. Error bars represent average \pm standard error. Bars for each shade tolerance group with the same letter are not significantly different $(P>0.05)$. 

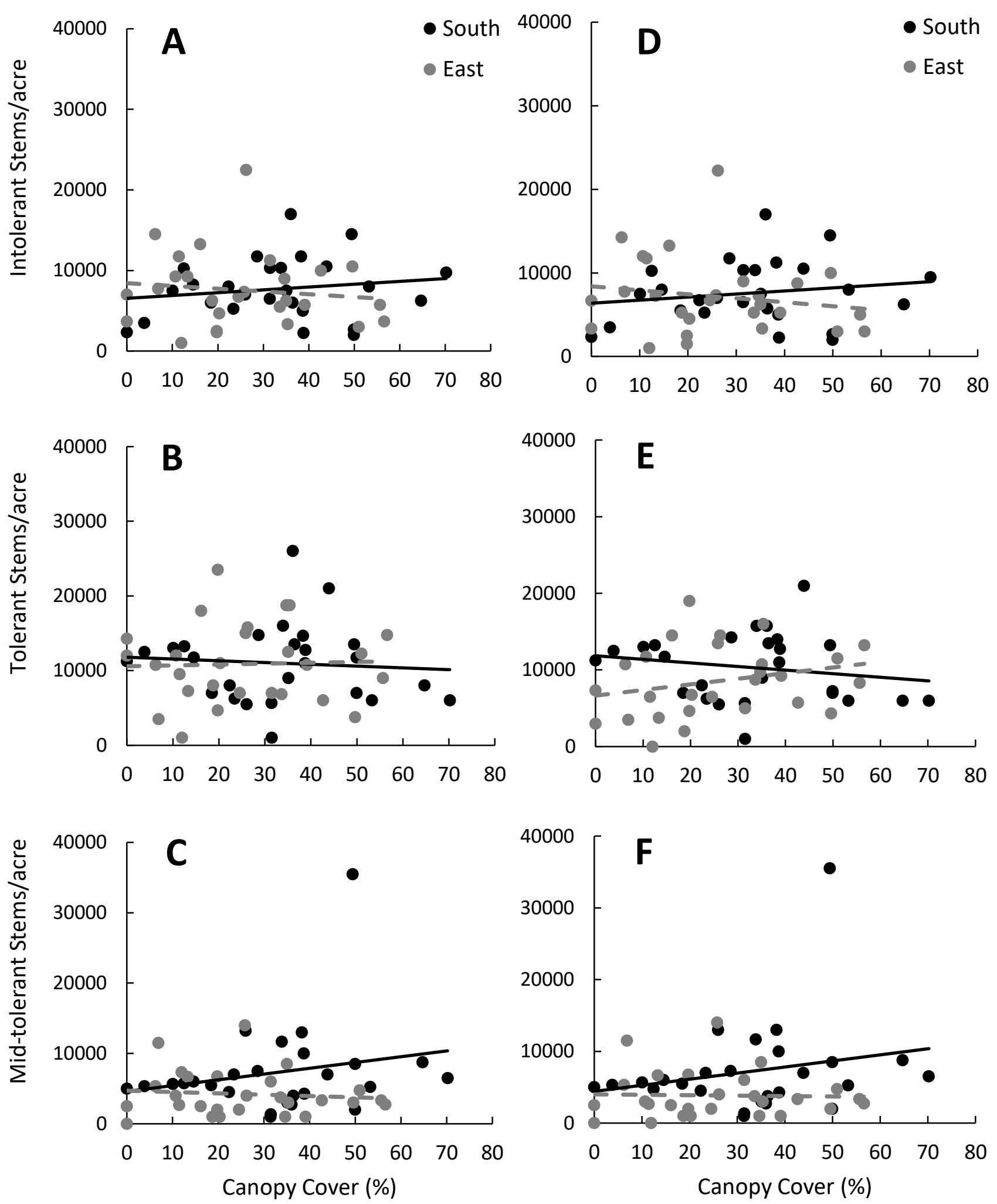

Figure 17. Stem density as a function of canopy cover from the residual cohort of total regeneration species (A-C) and only the commercial species (D-F) on the south and east aspects. Original values are displayed here for all three shade tolerance groups, while analysis required the use of log transformation values for only shadeintolerant and mid-tolerant groups. 


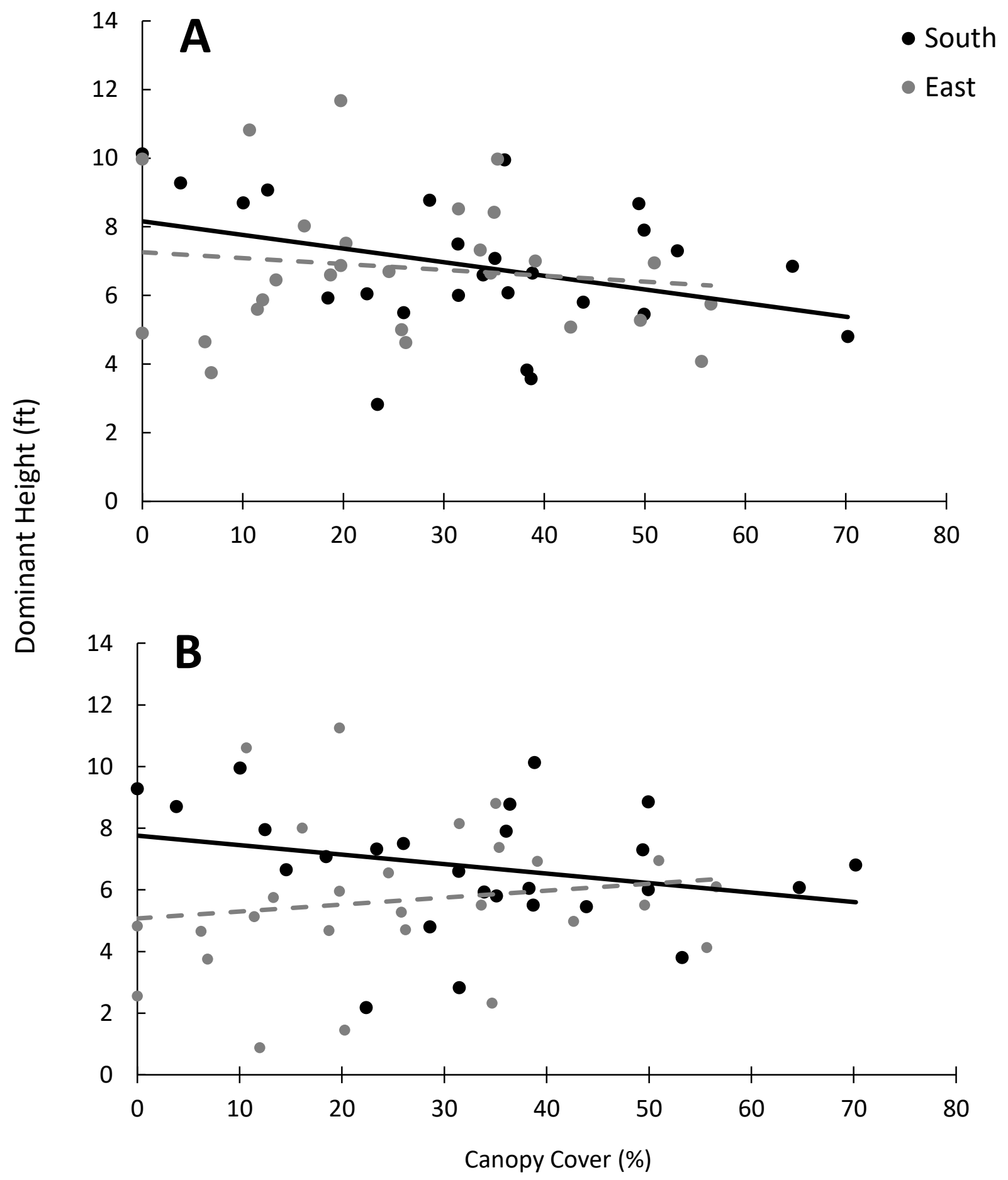

Figure 18. Dominant height of the regeneration stems as a function of canopy cover from the residual cohort of A) total regeneration species and B) only the commercial species. 


\section{APPENDICES}

Appendix A. Lumber prices of each species at each projected year. These prices were factored into calculating the present value of each species. Values adapted from the Hardwood Market Report for each projected year (2019-2039) (Johnson et al., 2018).

\begin{tabular}{|c|c|c|c|c|c|}
\hline \multirow[b]{2}{*}{ Year } & \multirow[b]{2}{*}{ Species } & \multicolumn{4}{|c|}{ Lumber Price (\$) (By Lumber Grade) } \\
\hline & & FAS & \#1C & \#2A & \#3A \\
\hline \multirow[t]{6}{*}{2018} & Hickory & 926 & 604 & 438 & --- \\
\hline & Northern Red Oak & 1,110 & 825 & 636 & 576 \\
\hline & Red Maple & 1,144 & 772 & 402 & --- \\
\hline & Sugar Maple & 1,198 & 943 & 579 & 410 \\
\hline & White Oak & 1,726 & 1,070 & 633 & 583 \\
\hline & Yellow-poplar & 835 & 448 & 316 & --- \\
\hline \multirow[t]{6}{*}{2019} & Hickory & 892 & 693 & 484 & $291^{a}$ \\
\hline & Northern Red Oak & 1,154 & 799 & 641 & 562 \\
\hline & Red Maple & 1,228 & 812 & 433 & $325^{a}$ \\
\hline & Sugar Maple & 1,459 & 1,083 & 655 & 455 \\
\hline & White Oak & 1,351 & 806 & 568 & 506 \\
\hline & Yellow-poplar & 834 & 491 & 356 & $262^{a}$ \\
\hline \multirow[t]{6}{*}{2024} & Hickory & 973 & 747 & 525 & 317 \\
\hline & Northern Red Oak & 1,224 & 841 & 697 & 612 \\
\hline & Red Maple & 1,342 & 876 & 464 & 348 \\
\hline & Sugar Maple & 1,593 & 1,176 & 713 & 497 \\
\hline & White Oak & 1,464 & 871 & 618 & 552 \\
\hline & Yellow-poplar & 892 & 520 & 380 & 276 \\
\hline \multirow[t]{6}{*}{2029} & Hickory & 1,054 & 801 & 566 & 344 \\
\hline & Northern Red Oak & 1,295 & 883 & 753 & 662 \\
\hline & Red Maple & 1,456 & 940 & 496 & 372 \\
\hline & Sugar Maple & 1,728 & 1,270 & 771 & 540 \\
\hline & White Oak & 1,576 & 937 & 669 & 598 \\
\hline & Yellow-poplar & 949 & 550 & 403 & 290 \\
\hline \multirow[t]{6}{*}{2034} & Hickory & 1,136 & 855 & 607 & 370 \\
\hline & Northern Red Oak & 1,366 & 925 & 809 & 712 \\
\hline & Red Maple & 1,571 & 1,004 & 527 & 395 \\
\hline & Sugar Maple & 1,863 & 1,364 & 829 & 583 \\
\hline & White Oak & 1,689 & 1,003 & 719 & 644 \\
\hline & Yellow-poplar & 1,006 & 579 & 426 & 303 \\
\hline
\end{tabular}


Appendix A (cont.)

\begin{tabular}{rrrrrr}
\hline & & \multicolumn{3}{c}{ Lumber Price (\$) (By Lumber Grade) } \\
\hline Year & Species & FAS & \#1C & \#2A & \#3A \\
\hline Ho39 & Hickory & 1,217 & 909 & 648 & 397 \\
& Northern Red Oak & 1,436 & 966 & 865 & 762 \\
& Red Maple & 1,685 & 1,068 & 558 & 419 \\
& Sugar Maple & 1,998 & 1,458 & 887 & 625 \\
& White Oak & 1,801 & 1,068 & 769 & 690 \\
& Yellow-poplar & 1,063 & 609 & 450 & 317 \\
\hline
\end{tabular}

a Lumber prices for \#3A lumber grade for projected years (2019-2039) were calculated as $75 \%$ of the price of \#2B (hickory and yellow-poplar) or \#2A (red maple) lumber grades in 2018. 
Appendix B. Expected lumber yield (percent, \%, of tree scale by lumber quality) determined for calculating the delivered log value for the lumber. Each table is sorted by tree grade and lumber quality for each species (hickory, northern red oak, red maple, sugar maple, white oak, yellow-poplar. Adapted from West Virginia University Appalachian Hardwood Center.

\section{Hickory}

\begin{tabular}{|c|c|c|c|c|c|c|c|c|c|c|c|c|c|c|c|}
\hline \multirow[b]{2}{*}{ DBH } & \multicolumn{5}{|c|}{ Tree Grade 1} & \multicolumn{5}{|c|}{ Tree Grade 2} & \multicolumn{5}{|c|}{ Tree Grade 3} \\
\hline & FAS & $\# 1 C$ & $\# 2 A$ & \#3A & Over/Under & FAS & $\# 1 C$ & $\# 2 A$ & \#3A & Over/Under & FAS & $\# 1 C$ & $\# 2 A$ & \#3A & Over/Under \\
\hline 12 & $2.5 \%$ & $2.3 \%$ & $34.9 \%$ & $55.8 \%$ & $-4.5 \%$ & $0.2 \%$ & $0.8 \%$ & $26.3 \%$ & $60.5 \%$ & $-12.2 \%$ & $0.0 \%$ & $0.0 \%$ & $22.3 \%$ & $60.2 \%$ & $-17.5 \%$ \\
\hline 13 & $3.2 \%$ & $7.5 \%$ & $33.2 \%$ & $48.0 \%$ & $-8.1 \%$ & $0.3 \%$ & $2.7 \%$ & $27.1 \%$ & $55.1 \%$ & $-14.8 \%$ & $0.0 \%$ & $1.0 \%$ & $22.2 \%$ & $60.4 \%$ & $-16.4 \%$ \\
\hline 14 & $5.0 \%$ & $11.5 \%$ & $32.3 \%$ & $42.5 \%$ & $-8.7 \%$ & $3.5 \%$ & $6.3 \%$ & $28.0 \%$ & $48.5 \%$ & $-13.7 \%$ & $2.4 \%$ & $10.1 \%$ & $22.4 \%$ & $53.6 \%$ & $-11.5 \%$ \\
\hline 15 & $8.0 \%$ & $14.9 \%$ & $31.8 \%$ & $38.4 \%$ & $-6.9 \%$ & $6.9 \%$ & $10.5 \%$ & $28.9 \%$ & $43.6 \%$ & $-10.1 \%$ & $4.6 \%$ & $13.6 \%$ & $22.9 \%$ & $48.5 \%$ & $-10.4 \%$ \\
\hline 16 & $10.8 \%$ & $17.9 \%$ & $26.5 \%$ & $35.4 \%$ & $-9.4 \%$ & $9.5 \%$ & $14.8 \%$ & $27.4 \%$ & $39.9 \%$ & $-8.4 \%$ & $5.6 \%$ & $16.6 \%$ & $27.6 \%$ & $44.7 \%$ & $-5.5 \%$ \\
\hline 17 & $12.6 \%$ & $19.5 \%$ & $25.2 \%$ & $31.4 \%$ & $-11.3 \%$ & $11.2 \%$ & $17.8 \%$ & $27.1 \%$ & $35.2 \%$ & $-8.7 \%$ & $6.2 \%$ & $18.3 \%$ & $30.7 \%$ & $39.7 \%$ & $-5.1 \%$ \\
\hline 18 & $15.0 \%$ & $20.9 \%$ & $24.4 \%$ & $28.5 \%$ & $-11.2 \%$ & $12.6 \%$ & $20.2 \%$ & $27.0 \%$ & $31.7 \%$ & $-8.5 \%$ & $6.7 \%$ & $19.8 \%$ & $32.3 \%$ & $36.1 \%$ & $-5.1 \%$ \\
\hline 19 & $17.6 \%$ & $22.3 \%$ & $23.9 \%$ & $26.3 \%$ & $-9.9 \%$ & $13.2 \%$ & $24.8 \%$ & $28.1 \%$ & $28.0 \%$ & $-5.9 \%$ & $7.2 \%$ & $21.1 \%$ & $32.2 \%$ & $33.3 \%$ & $-6.2 \%$ \\
\hline 20 & $19.9 \%$ & $23.5 \%$ & $23.6 \%$ & $24.6 \%$ & $-8.4 \%$ & $14.0 \%$ & $27.3 \%$ & $28.4 \%$ & $25.9 \%$ & $-4.4 \%$ & $7.6 \%$ & $22.4 \%$ & $32.2 \%$ & $31.2 \%$ & $-6.6 \%$ \\
\hline 21 & $22.0 \%$ & $24.7 \%$ & $23.4 \%$ & $23.2 \%$ & $-6.7 \%$ & $14.7 \%$ & $29.5 \%$ & $28.9 \%$ & $24.1 \%$ & $-2.8 \%$ & $8.0 \%$ & $23.6 \%$ & $32.4 \%$ & $29.5 \%$ & $-6.5 \%$ \\
\hline 22 & $23.9 \%$ & $25.8 \%$ & $23.4 \%$ & $22.2 \%$ & $-4.7 \%$ & $15.3 \%$ & $31.6 \%$ & $29.4 \%$ & $22.7 \%$ & $-1.0 \%$ & $8.4 \%$ & $24.7 \%$ & $32.7 \%$ & $28.1 \%$ & $-6.1 \%$ \\
\hline 23 & $25.3 \%$ & $26.6 \%$ & $23.1 \%$ & $21.0 \%$ & $-4.0 \%$ & $15.8 \%$ & $33.1 \%$ & $29.6 \%$ & $21.3 \%$ & $-0.2 \%$ & $8.6 \%$ & $25.5 \%$ & $32.7 \%$ & $26.7 \%$ & $-6.5 \%$ \\
\hline 24 & $26.7 \%$ & $27.3 \%$ & $23.0 \%$ & $20.1 \%$ & $-2.9 \%$ & $16.2 \%$ & $34.6 \%$ & $29.9 \%$ & $20.1 \%$ & $0.8 \%$ & $8.9 \%$ & $26.3 \%$ & $32.8 \%$ & $25.5 \%$ & $-6.5 \%$ \\
\hline 25 & $27.7 \%$ & $27.8 \%$ & $22.7 \%$ & $19.1 \%$ & $-2.7 \%$ & $16.5 \%$ & $35.6 \%$ & $29.9 \%$ & $19.0 \%$ & $1.0 \%$ & $9.1 \%$ & $26.7 \%$ & $32.6 \%$ & $24.3 \%$ & $-7.3 \%$ \\
\hline 26 & $28.6 \%$ & $28.2 \%$ & $22.5 \%$ & $18.3 \%$ & $-2.4 \%$ & $16.8 \%$ & $36.6 \%$ & $30.0 \%$ & $18.0 \%$ & $1.4 \%$ & $9.2 \%$ & $27.2 \%$ & $32.5 \%$ & $23.3 \%$ & $-7.8 \%$ \\
\hline 27 & $29.3 \%$ & $28.5 \%$ & $22.2 \%$ & $17.5 \%$ & $-2.5 \%$ & $17.0 \%$ & $37.2 \%$ & $29.9 \%$ & $17.0 \%$ & $1.1 \%$ & $9.3 \%$ & $27.5 \%$ & $32.3 \%$ & $22.3 \%$ & $-8.6 \%$ \\
\hline 28 & $29.9 \%$ & $28.8 \%$ & $22.0 \%$ & $16.8 \%$ & $-2.5 \%$ & $17.1 \%$ & $37.9 \%$ & $29.9 \%$ & $16.2 \%$ & $1.1 \%$ & $9.4 \%$ & $27.8 \%$ & $32.2 \%$ & $21.4 \%$ & $-9.2 \%$ \\
\hline 29 & $30.6 \%$ & $29.1 \%$ & $21.9 \%$ & $16.3 \%$ & $-2.1 \%$ & $17.3 \%$ & $38.6 \%$ & $30.0 \%$ & $15.5 \%$ & $1.4 \%$ & $9.5 \%$ & $28.2 \%$ & $32.2 \%$ & $20.7 \%$ & $-9.4 \%$ \\
\hline 30 & $31.3 \%$ & $29.5 \%$ & $21.8 \%$ & $15.8 \%$ & $-1.6 \%$ & $17.6 \%$ & $39.4 \%$ & $30.2 \%$ & $14.9 \%$ & $2.1 \%$ & $9.7 \%$ & $28.6 \%$ & $32.2 \%$ & $20.2 \%$ & $-9.3 \%$ \\
\hline
\end{tabular}




\section{Appendix B (Cont.)}

\section{Northern Red Oak}

\begin{tabular}{|c|c|c|c|c|c|c|c|c|c|c|c|c|c|c|c|}
\hline \multicolumn{6}{|c|}{ Tree Grade 1} & \multicolumn{5}{|c|}{ Tree Grade 2} & \multicolumn{5}{|c|}{ Tree Grade 3} \\
\hline DBH & FAS & $\# 1 C$ & $\# 2 A$ & \#3A & Over/Under & FAS & $\# 1 C$ & $\# 2 A$ & \#3A & Over/Under & FAS & $\# 1 C$ & $\# 2 A$ & \#3A & Over/Under \\
\hline 12 & $2.1 \%$ & $6.5 \%$ & $46.0 \%$ & $35.7 \%$ & $-9.7 \%$ & $1.3 \%$ & $4.0 \%$ & $32.4 \%$ & $51.4 \%$ & $-10.9 \%$ & $0.0 \%$ & $0.0 \%$ & $41.2 \%$ & $67.8 \%$ & $9.0 \%$ \\
\hline 13 & $4.6 \%$ & $12.1 \%$ & $44.9 \%$ & $30.5 \%$ & $-7.9 \%$ & $4.4 \%$ & $13.7 \%$ & $32.7 \%$ & $44.9 \%$ & $-4.3 \%$ & $1.5 \%$ & $10.5 \%$ & $37.5 \%$ & $56.1 \%$ & $5.6 \%$ \\
\hline 14 & $6.4 \%$ & $20.3 \%$ & $39.9 \%$ & $27.1 \%$ & $-6.3 \%$ & $5.7 \%$ & $16.7 \%$ & $31.0 \%$ & $40.5 \%$ & $-6.1 \%$ & $3.8 \%$ & $14.5 \%$ & $35.0 \%$ & $47.9 \%$ & $1.2 \%$ \\
\hline 15 & $12.0 \%$ & $23.1 \%$ & $36.3 \%$ & $24.6 \%$ & $-4.0 \%$ & $8.8 \%$ & $19.3 \%$ & $29.9 \%$ & $37.3 \%$ & $-4.7 \%$ & $5.6 \%$ & $17.9 \%$ & $33.4 \%$ & $41.8 \%$ & $-1.3 \%$ \\
\hline 16 & $18.1 \%$ & $25.6 \%$ & $33.6 \%$ & $22.7 \%$ & $0.0 \%$ & $12.2 \%$ & $21.6 \%$ & $29.2 \%$ & $35.0 \%$ & $-2.0 \%$ & $7.2 \%$ & $20.9 \%$ & $32.3 \%$ & $37.1 \%$ & $-2.5 \%$ \\
\hline 17 & $22.3 \%$ & $26.6 \%$ & $29.9 \%$ & $20.2 \%$ & $-1.0 \%$ & $14.4 \%$ & $22.5 \%$ & $27.4 \%$ & $31.7 \%$ & $-4.0 \%$ & $8.2 \%$ & $22.4 \%$ & $30.0 \%$ & $35.0 \%$ & $-4.4 \%$ \\
\hline 18 & $25.8 \%$ & $27.5 \%$ & $27.3 \%$ & $18.3 \%$ & $-1.1 \%$ & $16.3 \%$ & $23.5 \%$ & $26.2 \%$ & $29.2 \%$ & $-4.8 \%$ & $9.1 \%$ & $23.8 \%$ & $28.5 \%$ & $34.5 \%$ & $-4.1 \%$ \\
\hline 19 & $28.8 \%$ & $28.5 \%$ & $25.3 \%$ & $17.0 \%$ & $-0.4 \%$ & $17.1 \%$ & $28.3 \%$ & $25.5 \%$ & $18.2 \%$ & $-10.9 \%$ & $9.9 \%$ & $25.1 \%$ & $27.4 \%$ & $33.8 \%$ & $-3.8 \%$ \\
\hline 20 & $31.6 \%$ & $29.5 \%$ & $23.8 \%$ & $15.9 \%$ & $0.8 \%$ & $17.3 \%$ & $29.9 \%$ & $24.5 \%$ & $17.3 \%$ & $-11.0 \%$ & $10.5 \%$ & $26.3 \%$ & $26.6 \%$ & $31.2 \%$ & $-5.4 \%$ \\
\hline 21 & $34.1 \%$ & $30.5 \%$ & $22.5 \%$ & $15.0 \%$ & $2.1 \%$ & $18.4 \%$ & $31.3 \%$ & $23.8 \%$ & $16.6 \%$ & $-9.9 \%$ & $11.2 \%$ & $27.5 \%$ & $26.1 \%$ & $29.1 \%$ & $-6.1 \%$ \\
\hline 22 & $36.4 \%$ & $31.4 \%$ & $21.6 \%$ & $14.3 \%$ & $3.7 \%$ & $19.5 \%$ & $33.5 \%$ & $23.9 \%$ & $16.0 \%$ & $-7.1 \%$ & $11.8 \%$ & $28.6 \%$ & $25.7 \%$ & $27.4 \%$ & $-6.5 \%$ \\
\hline 23 & $38.1 \%$ & $32.0 \%$ & $20.5 \%$ & $13.6 \%$ & $4.2 \%$ & $20.3 \%$ & $35.1 \%$ & $23.8 \%$ & $15.4 \%$ & $-5.4 \%$ & $12.2 \%$ & $29.3 \%$ & $25.1 \%$ & $25.7 \%$ & $-7.7 \%$ \\
\hline 24 & $39.7 \%$ & $32.6 \%$ & $19.7 \%$ & $13.0 \%$ & $5.0 \%$ & $21.0 \%$ & $36.7 \%$ & $23.8 \%$ & $15.0 \%$ & $-3.5 \%$ & $12.6 \%$ & $30.1 \%$ & $24.7 \%$ & $24.3 \%$ & $-8.3 \%$ \\
\hline 25 & $40.8 \%$ & $32.9 \%$ & $18.8 \%$ & $12.4 \%$ & $4.9 \%$ & $21.5 \%$ & $37.8 \%$ & $23.6 \%$ & $14.4 \%$ & $-2.7 \%$ & $12.9 \%$ & $30.5 \%$ & $24.2 \%$ & $22.8 \%$ & $-9.6 \%$ \\
\hline 26 & $41.9 \%$ & $33.3 \%$ & $18.0 \%$ & $11.9 \%$ & $5.1 \%$ & $22.0 \%$ & $38.9 \%$ & $23.4 \%$ & $14.0 \%$ & $-1.7 \%$ & $13.2 \%$ & $31.0 \%$ & $23.8 \%$ & $21.7 \%$ & $-10.3 \%$ \\
\hline 27 & $42.6 \%$ & $33.4 \%$ & $17.3 \%$ & $11.4 \%$ & $4.7 \%$ & $22.3 \%$ & $39.6 \%$ & $23.2 \%$ & $13.5 \%$ & $-1.4 \%$ & $13.4 \%$ & $31.2 \%$ & $23.3 \%$ & $20.5 \%$ & $-11.6 \%$ \\
\hline 28 & $43.4 \%$ & $33.6 \%$ & $16.7 \%$ & $11.0 \%$ & $4.7 \%$ & $22.7 \%$ & $40.3 \%$ & $23.1 \%$ & $13.2 \%$ & $-0.7 \%$ & $13.5 \%$ & $31.5 \%$ & $23.0 \%$ & $19.5 \%$ & $-12.5 \%$ \\
\hline 29 & $44.2 \%$ & $33.8 \%$ & $16.2 \%$ & $10.6 \%$ & $4.8 \%$ & $23.0 \%$ & $41.1 \%$ & $23.0 \%$ & $12.9 \%$ & $0.0 \%$ & $13.7 \%$ & $31.9 \%$ & $22.7 \%$ & $18.7 \%$ & $-13.0 \%$ \\
\hline 30 & $45.0 \%$ & $34.1 \%$ & $15.8 \%$ & $10.4 \%$ & $5.3 \%$ & $23.4 \%$ & $41.8 \%$ & $23.0 \%$ & $12.7 \%$ & $0.9 \%$ & $13.9 \%$ & $32.2 \%$ & $22.5 \%$ & $18.0 \%$ & $-13.4 \%$ \\
\hline
\end{tabular}




\section{Appendix B (Cont.)}

\section{Red Maple}

\begin{tabular}{|c|c|c|c|c|c|c|c|c|c|c|c|c|c|c|c|}
\hline \multirow[b]{2}{*}{ DBH } & \multicolumn{5}{|c|}{ Tree Grade 1} & \multicolumn{5}{|c|}{ Tree Grade 2} & \multicolumn{5}{|c|}{ Tree Grade 3} \\
\hline & FAS & $\# 1 C$ & $\# 2 A$ & $\# 3 A$ & Over/Under & FAS & $\# 1 \mathrm{C}$ & $\# 2 A$ & $\# 3 A$ & Over/Under & FAS & $\# 1 \mathrm{C}$ & $\# 2 A$ & $\# 3 A$ & Over/Under \\
\hline 12 & $2.1 \%$ & $20.0 \%$ & $61.9 \%$ & $24.6 \%$ & $8.6 \%$ & $1.0 \%$ & $12.3 \%$ & $79.9 \%$ & $19.6 \%$ & $12.8 \%$ & $0.0 \%$ & $2.9 \%$ & $71.9 \%$ & $23.4 \%$ & $-1.8 \%$ \\
\hline 13 & $6.2 \%$ & $20.9 \%$ & $54.7 \%$ & $22.2 \%$ & $4.0 \%$ & $1.6 \%$ & $18.0 \%$ & $69.0 \%$ & $18.7 \%$ & $7.3 \%$ & $0.0 \%$ & $7.2 \%$ & $63.5 \%$ & $23.3 \%$ & $-6.0 \%$ \\
\hline 14 & $8.0 \%$ & $23.5 \%$ & $49.8 \%$ & $21.1 \%$ & $2.4 \%$ & $2.3 \%$ & $21.3 \%$ & $61.5 \%$ & $18.8 \%$ & $3.9 \%$ & $0.5 \%$ & $9.1 \%$ & $57.7 \%$ & $23.4 \%$ & $-9.3 \%$ \\
\hline 15 & $10.1 \%$ & $25.3 \%$ & $46.3 \%$ & $20.3 \%$ & $2.0 \%$ & $3.0 \%$ & $22.8 \%$ & $55.9 \%$ & $20.0 \%$ & $1.7 \%$ & $1.1 \%$ & $10.7 \%$ & $53.6 \%$ & $23.6 \%$ & $-11.0 \%$ \\
\hline 16 & $11.4 \%$ & $26.6 \%$ & $41.8 \%$ & $19.7 \%$ & $-0.5 \%$ & $3.8 \%$ & $24.0 \%$ & $51.7 \%$ & $21.0 \%$ & $0.5 \%$ & $1.6 \%$ & $12.2 \%$ & $50.6 \%$ & $23.9 \%$ & $-11.7 \%$ \\
\hline 17 & $12.3 \%$ & $26.6 \%$ & $39.9 \%$ & $18.8 \%$ & $-2.4 \%$ & $3.5 \%$ & $27.0 \%$ & $46.2 \%$ & $21.4 \%$ & $-1.9 \%$ & $1.6 \%$ & $14.7 \%$ & $46.1 \%$ & $23.5 \%$ & $-14.1 \%$ \\
\hline 18 & $12.6 \%$ & $28.3 \%$ & $37.1 \%$ & $18.2 \%$ & $-3.8 \%$ & $3.4 \%$ & $29.3 \%$ & $42.2 \%$ & $21.8 \%$ & $-3.3 \%$ & $1.6 \%$ & $17.2 \%$ & $42.8 \%$ & $23.3 \%$ & $-15.1 \%$ \\
\hline 19 & $12.2 \%$ & $29.9 \%$ & $35.0 \%$ & $17.7 \%$ & $-5.2 \%$ & $3.5 \%$ & $30.0 \%$ & $39.1 \%$ & $22.2 \%$ & $-5.2 \%$ & $1.8 \%$ & $18.8 \%$ & $40.4 \%$ & $23.3 \%$ & $-15.7 \%$ \\
\hline 20 & $12.1 \%$ & $31.3 \%$ & $33.5 \%$ & $17.4 \%$ & $-5.7 \%$ & $3.7 \%$ & $30.7 \%$ & $36.7 \%$ & $22.7 \%$ & $-6.2 \%$ & $1.9 \%$ & $19.3 \%$ & $38.6 \%$ & $23.3 \%$ & $-16.9 \%$ \\
\hline 21 & $12.2 \%$ & $32.6 \%$ & $32.3 \%$ & $17.1 \%$ & $-5.8 \%$ & $3.9 \%$ & $31.4 \%$ & $34.9 \%$ & $23.1 \%$ & $-6.7 \%$ & $2.1 \%$ & $19.9 \%$ & $37.2 \%$ & $23.4 \%$ & $-17.4 \%$ \\
\hline 22 & $12.4 \%$ & $33.8 \%$ & $31.4 \%$ & $16.9 \%$ & $-5.5 \%$ & $4.3 \%$ & $32.1 \%$ & $33.4 \%$ & $23.5 \%$ & $-6.7 \%$ & $2.3 \%$ & $20.5 \%$ & $36.2 \%$ & $23.5 \%$ & $-17.5 \%$ \\
\hline 23 & $12.2 \%$ & $34.7 \%$ & $30.3 \%$ & $16.7 \%$ & $-6.1 \%$ & $4.4 \%$ & $32.5 \%$ & $31.8 \%$ & $23.7 \%$ & $-7.6 \%$ & $2.4 \%$ & $20.8 \%$ & $34.9 \%$ & $23.5 \%$ & $-18.4 \%$ \\
\hline 24 & $12.2 \%$ & $35.5 \%$ & $29.5 \%$ & $16.5 \%$ & $-6.3 \%$ & $4.5 \%$ & $32.9 \%$ & $30.5 \%$ & $24.0 \%$ & $-8.1 \%$ & $2.5 \%$ & $21.2 \%$ & $34.0 \%$ & $23.5 \%$ & $-18.8 \%$ \\
\hline 25 & $12.0 \%$ & $36.1 \%$ & $28.6 \%$ & $16.3 \%$ & $-7.0 \%$ & $4.5 \%$ & $33.1 \%$ & $29.1 \%$ & $24.1 \%$ & $-9.2 \%$ & $2.6 \%$ & $21.3 \%$ & $32.9 \%$ & $23.4 \%$ & $-19.8 \%$ \\
\hline 26 & $11.9 \%$ & $36.7 \%$ & $27.8 \%$ & $16.1 \%$ & $-7.5 \%$ & $4.5 \%$ & $33.3 \%$ & $28.0 \%$ & $24.2 \%$ & $-10.0 \%$ & $2.6 \%$ & $21.5 \%$ & $32.0 \%$ & $23.4 \%$ & $-20.5 \%$ \\
\hline 27 & $11.6 \%$ & $37.0 \%$ & $27.0 \%$ & $15.9 \%$ & $-8.5 \%$ & $4.4 \%$ & $33.4 \%$ & $26.9 \%$ & $24.3 \%$ & $-11.0 \%$ & $2.6 \%$ & $21.6 \%$ & $31.1 \%$ & $23.3 \%$ & $-21.4 \%$ \\
\hline 28 & $11.4 \%$ & $37.4 \%$ & $26.4 \%$ & $15.8 \%$ & $-9.0 \%$ & $4.3 \%$ & $33.6 \%$ & $25.9 \%$ & $24.4 \%$ & $-11.8 \%$ & $2.6 \%$ & $21.7 \%$ & $30.3 \%$ & $23.3 \%$ & $-22.1 \%$ \\
\hline 29 & $11.3 \%$ & $37.8 \%$ & $25.8 \%$ & $15.7 \%$ & $-9.4 \%$ & $4.4 \%$ & $33.7 \%$ & $25.2 \%$ & $24.5 \%$ & $-12.2 \%$ & $2.6 \%$ & $21.8 \%$ & $29.7 \%$ & $23.2 \%$ & $-22.7 \%$ \\
\hline 30 & $11.3 \%$ & $38.2 \%$ & $25.4 \%$ & $15.6 \%$ & $-9.5 \%$ & $4.4 \%$ & $34.0 \%$ & $24.5 \%$ & $24.6 \%$ & $-12.5 \%$ & $2.7 \%$ & $22.0 \%$ & $29.2 \%$ & $23.3 \%$ & $-22.8 \%$ \\
\hline
\end{tabular}




\section{Appendix B (Cont.)}

\section{Sugar Maple}

\begin{tabular}{|c|c|c|c|c|c|c|c|c|c|c|c|c|c|c|c|}
\hline \multirow[b]{2}{*}{ DBH } & \multicolumn{5}{|c|}{ Tree Grade 1} & \multicolumn{5}{|c|}{ Tree Grade 2} & \multicolumn{5}{|c|}{ Tree Grade 3} \\
\hline & FAS & \#1C & $\# 2 A$ & $\# 3 A$ & Over/Under & FAS & $\# 1 C$ & $\# 2 A$ & \#3A & Over/Under & FAS & $\# 1 C$ & $\# 2 A$ & \#3A & Over/Under \\
\hline 12 & $4.9 \%$ & $13.5 \%$ & $43.8 \%$ & $43.4 \%$ & $5.6 \%$ & $5.2 \%$ & $11.7 \%$ & $24.9 \%$ & $50.2 \%$ & $-8.0 \%$ & $4.7 \%$ & $10.4 \%$ & $16.2 \%$ & $72.4 \%$ & $3.7 \%$ \\
\hline 13 & $6.7 \%$ & $15.9 \%$ & $39.2 \%$ & $38.9 \%$ & $0.7 \%$ & $8.0 \%$ & $15.6 \%$ & $24.0 \%$ & $43.0 \%$ & $-9.4 \%$ & $5.5 \%$ & $12.7 \%$ & $17.2 \%$ & $62.9 \%$ & $-1.7 \%$ \\
\hline 14 & $9.3 \%$ & $17.9 \%$ & $35.1 \%$ & $35.9 \%$ & $-1.8 \%$ & $10.8 \%$ & $18.3 \%$ & $23.5 \%$ & $38.0 \%$ & $-9.4 \%$ & $6.2 \%$ & $14.7 \%$ & $18.2 \%$ & $56.4 \%$ & $-4.5 \%$ \\
\hline 15 & $14.0 \%$ & $19.7 \%$ & $31.2 \%$ & $33.8 \%$ & $-1.3 \%$ & $13.6 \%$ & $20.2 \%$ & $23.3 \%$ & $34.2 \%$ & $-8.7 \%$ & $6.8 \%$ & $16.3 \%$ & $19.1 \%$ & $51.6 \%$ & $-6.2 \%$ \\
\hline 16 & $19.6 \%$ & $21.3 \%$ & $27.4 \%$ & $32.3 \%$ & $0.6 \%$ & $16.4 \%$ & $21.5 \%$ & $23.3 \%$ & $31.4 \%$ & $-7.4 \%$ & $7.4 \%$ & $17.9 \%$ & $20.0 \%$ & $44.0 \%$ & $-10.7 \%$ \\
\hline 17 & $24.0 \%$ & $21.7 \%$ & $22.7 \%$ & $29.7 \%$ & $-1.9 \%$ & $18.3 \%$ & $21.5 \%$ & $22.4 \%$ & $27.8 \%$ & $-10.0 \%$ & $7.6 \%$ & $18.4 \%$ & $20.0 \%$ & $43.1 \%$ & $-10.9 \%$ \\
\hline 18 & $24.5 \%$ & $22.3 \%$ & $22.2 \%$ & $27.9 \%$ & $-3.1 \%$ & $18.3 \%$ & $23.1 \%$ & $21.8 \%$ & $25.1 \%$ & $-11.7 \%$ & $7.8 \%$ & $18.9 \%$ & $20.1 \%$ & $39.6 \%$ & $-13.6 \%$ \\
\hline 19 & $25.1 \%$ & $22.8 \%$ & $22.0 \%$ & $26.6 \%$ & $-3.5 \%$ & $18.5 \%$ & $24.7 \%$ & $21.5 \%$ & $23.1 \%$ & $-12.2 \%$ & $8.0 \%$ & $19.5 \%$ & $20.3 \%$ & $36.9 \%$ & $-15.3 \%$ \\
\hline 20 & $25.7 \%$ & $23.4 \%$ & $22.0 \%$ & $25.7 \%$ & $-3.2 \%$ & $18.7 \%$ & $26.1 \%$ & $21.3 \%$ & $21.5 \%$ & $-12.4 \%$ & $8.2 \%$ & $20.0 \%$ & $20.5 \%$ & $34.8 \%$ & $-16.5 \%$ \\
\hline 21 & $26.3 \%$ & $24.1 \%$ & $22.0 \%$ & $25.0 \%$ & $-2.6 \%$ & $19.0 \%$ & $27.4 \%$ & $21.2 \%$ & $20.2 \%$ & $-12.2 \%$ & $8.5 \%$ & $20.6 \%$ & $20.9 \%$ & $33.2 \%$ & $-16.8 \%$ \\
\hline 22 & $27.0 \%$ & $24.7 \%$ & $22.1 \%$ & $24.5 \%$ & $-1.7 \%$ & $19.3 \%$ & $28.7 \%$ & $21.3 \%$ & $19.2 \%$ & $-11.5 \%$ & $8.7 \%$ & $21.2 \%$ & $21.2 \%$ & $32.0 \%$ & $-16.9 \%$ \\
\hline 23 & $27.3 \%$ & $25.0 \%$ & $22.1 \%$ & $23.8 \%$ & $-1.8 \%$ & $19.5 \%$ & $29.6 \%$ & $21.1 \%$ & $18.1 \%$ & $-11.7 \%$ & $8.8 \%$ & $21.6 \%$ & $21.4 \%$ & $30.5 \%$ & $-17.7 \%$ \\
\hline 24 & $27.7 \%$ & $25.4 \%$ & $22.1 \%$ & $23.3 \%$ & $-1.5 \%$ & $19.6 \%$ & $30.5 \%$ & $21.1 \%$ & $17.3 \%$ & $-11.5 \%$ & $9.0 \%$ & $21.9 \%$ & $21.6 \%$ & $29.4 \%$ & $-18.1 \%$ \\
\hline 25 & $27.8 \%$ & $25.6 \%$ & $21.9 \%$ & $22.7 \%$ & $-2.0 \%$ & $19.6 \%$ & $31.0 \%$ & $20.9 \%$ & $16.4 \%$ & $-12.1 \%$ & $9.0 \%$ & $22.1 \%$ & $21.6 \%$ & $28.2 \%$ & $-19.1 \%$ \\
\hline 26 & $28.0 \%$ & $25.8 \%$ & $21.8 \%$ & $22.2 \%$ & $-2.2 \%$ & $19.7 \%$ & $31.6 \%$ & $20.8 \%$ & $15.6 \%$ & $-12.3 \%$ & $9.1 \%$ & $22.3 \%$ & $21.7 \%$ & $27.3 \%$ & $-19.6 \%$ \\
\hline 27 & $28.0 \%$ & $25.8 \%$ & $21.6 \%$ & $21.7 \%$ & $-2.9 \%$ & $19.6 \%$ & $31.9 \%$ & $20.5 \%$ & $14.9 \%$ & $-13.1 \%$ & $9.1 \%$ & $22.3 \%$ & $21.6 \%$ & $26.3 \%$ & $-20.7 \%$ \\
\hline 28 & $28.1 \%$ & $25.9 \%$ & $21.5 \%$ & $21.2 \%$ & $-3.3 \%$ & $19.6 \%$ & $32.2 \%$ & $20.4 \%$ & $14.3 \%$ & $-13.5 \%$ & $9.2 \%$ & $22.4 \%$ & $21.6 \%$ & $25.4 \%$ & $-21.4 \%$ \\
\hline 29 & $28.3 \%$ & $26.1 \%$ & $21.5 \%$ & $20.9 \%$ & $-3.2 \%$ & $19.7 \%$ & $32.6 \%$ & $20.3 \%$ & $13.8 \%$ & $-13.6 \%$ & $9.2 \%$ & $22.6 \%$ & $21.7 \%$ & $24.8 \%$ & $-21.7 \%$ \\
\hline 30 & $28.5 \%$ & $26.3 \%$ & $21.5 \%$ & $20.7 \%$ & $-3.0 \%$ & $19.7 \%$ & $33.0 \%$ & $20.3 \%$ & $13.4 \%$ & $-13.6 \%$ & $9.3 \%$ & $22.8 \%$ & $21.8 \%$ & $24.2 \%$ & $-21.9 \%$ \\
\hline
\end{tabular}




\section{Appendix B (Cont.)}

\section{White Oak}

\begin{tabular}{|c|c|c|c|c|c|c|c|c|c|c|c|c|c|c|c|}
\hline \multirow[b]{2}{*}{ DBH } & \multicolumn{5}{|c|}{ Tree Grade 1} & \multicolumn{5}{|c|}{ Tree Grade 2} & \multicolumn{5}{|c|}{ Tree Grade 3} \\
\hline & FAS & $\# 1 \mathrm{C}$ & $\# 2 A$ & $\# 3 A$ & Over/Under & FAS & $\# 1 C$ & $\# 2 A$ & \#3A & Over/Under & FAS & $\# 1 C$ & $\# 2 A$ & \#3A & Over/Under \\
\hline 12 & $0.0 \%$ & $1.0 \%$ & $27.9 \%$ & $47.2 \%$ & $-23.9 \%$ & $0.0 \%$ & $0.5 \%$ & $25.7 \%$ & $55.0 \%$ & $-18.8 \%$ & $0.0 \%$ & $0.0 \%$ & $23.5 \%$ & $55.7 \%$ & $-20.8 \%$ \\
\hline 13 & $0.2 \%$ & $5.9 \%$ & $29.3 \%$ & $41.3 \%$ & $-23.3 \%$ & $0.1 \%$ & $3.7 \%$ & $28.1 \%$ & $48.0 \%$ & $-20.1 \%$ & $0.0 \%$ & $1.5 \%$ & $26.9 \%$ & $54.7 \%$ & $-16.9 \%$ \\
\hline 14 & $2.6 \%$ & $9.7 \%$ & $30.6 \%$ & $37.2 \%$ & $-19.9 \%$ & $1.8 \%$ & $7.7 \%$ & $30.2 \%$ & $43.2 \%$ & $-17.1 \%$ & $1.1 \%$ & $5.7 \%$ & $29.8 \%$ & $49.2 \%$ & $-14.2 \%$ \\
\hline 15 & $7.0 \%$ & $12.8 \%$ & $31.9 \%$ & $34.3 \%$ & $-14.0 \%$ & $5.3 \%$ & $11.0 \%$ & $32.2 \%$ & $39.8 \%$ & $-11.7 \%$ & $3.6 \%$ & $9.2 \%$ & $32.4 \%$ & $45.3 \%$ & $-9.5 \%$ \\
\hline 16 & $11.3 \%$ & $15.5 \%$ & $23.1 \%$ & $32.1 \%$ & $-18.0 \%$ & $7.6 \%$ & $13.9 \%$ & $29.0 \%$ & $37.2 \%$ & $-12.3 \%$ & $4.0 \%$ & $12.2 \%$ & $34.9 \%$ & $42.3 \%$ & $-6.6 \%$ \\
\hline 17 & $14.2 \%$ & $17.1 \%$ & $23.1 \%$ & $29.0 \%$ & $-16.6 \%$ & $9.2 \%$ & $15.6 \%$ & $29.3 \%$ & $33.6 \%$ & $-12.3 \%$ & $4.1 \%$ & $14.1 \%$ & $35.4 \%$ & $38.2 \%$ & $-8.2 \%$ \\
\hline 18 & $16.7 \%$ & $18.5 \%$ & $23.3 \%$ & $26.8 \%$ & $-14.7 \%$ & $10.5 \%$ & $17.1 \%$ & $29.7 \%$ & $31.0 \%$ & $-11.7 \%$ & $4.3 \%$ & $15.8 \%$ & $36.1 \%$ & $35.2 \%$ & $-8.6 \%$ \\
\hline 19 & $18.8 \%$ & $19.7 \%$ & $23.6 \%$ & $25.1 \%$ & $-12.8 \%$ & $10.4 \%$ & $23.4 \%$ & $32.1 \%$ & $26.8 \%$ & $-7.3 \%$ & $4.5 \%$ & $17.2 \%$ & $36.9 \%$ & $32.9 \%$ & $-8.5 \%$ \\
\hline 20 & $20.7 \%$ & $20.9 \%$ & $24.0 \%$ & $23.8 \%$ & $-10.6 \%$ & $10.7 \%$ & $25.7 \%$ & $33.0 \%$ & $25.2 \%$ & $-5.4 \%$ & $4.6 \%$ & $18.5 \%$ & $37.8 \%$ & $31.2 \%$ & $-7.9 \%$ \\
\hline 21 & $22.5 \%$ & $21.9 \%$ & $24.5 \%$ & $22.8 \%$ & $-8.3 \%$ & $10.9 \%$ & $27.8 \%$ & $34.0 \%$ & $23.9 \%$ & $-3.4 \%$ & $4.8 \%$ & $19.7 \%$ & $38.7 \%$ & $29.9 \%$ & $-6.9 \%$ \\
\hline 22 & $24.1 \%$ & $23.0 \%$ & $25.0 \%$ & $22.0 \%$ & $-5.9 \%$ & $11.2 \%$ & $29.7 \%$ & $34.9 \%$ & $22.9 \%$ & $-1.3 \%$ & $4.9 \%$ & $20.9 \%$ & $39.7 \%$ & $28.8 \%$ & $-5.7 \%$ \\
\hline 23 & $25.3 \%$ & $23.7 \%$ & $25.2 \%$ & $21.1 \%$ & $-4.7 \%$ & $11.3 \%$ & $31.1 \%$ & $35.4 \%$ & $21.8 \%$ & $-0.4 \%$ & $5.0 \%$ & $21.7 \%$ & $40.2 \%$ & $27.6 \%$ & $-5.5 \%$ \\
\hline 24 & $26.4 \%$ & $24.4 \%$ & $25.4 \%$ & $20.5 \%$ & $-3.3 \%$ & $11.5 \%$ & $32.4 \%$ & $36.0 \%$ & $20.9 \%$ & $0.8 \%$ & $5.1 \%$ & $22.5 \%$ & $40.8 \%$ & $26.7 \%$ & $-4.9 \%$ \\
\hline 25 & $27.2 \%$ & $24.8 \%$ & $25.5 \%$ & $19.7 \%$ & $-2.8 \%$ & $11.5 \%$ & $33.4 \%$ & $36.3 \%$ & $19.9 \%$ & $1.1 \%$ & $5.2 \%$ & $23.0 \%$ & $41.0 \%$ & $25.7 \%$ & $-5.1 \%$ \\
\hline 26 & $28.0 \%$ & $25.3 \%$ & $25.6 \%$ & $19.1 \%$ & $-2.0 \%$ & $11.6 \%$ & $34.3 \%$ & $36.6 \%$ & $19.2 \%$ & $1.7 \%$ & $5.3 \%$ & $23.5 \%$ & $41.3 \%$ & $24.9 \%$ & $-5.0 \%$ \\
\hline 27 & $28.5 \%$ & $25.5 \%$ & $25.5 \%$ & $18.4 \%$ & $-2.1 \%$ & $11.6 \%$ & $34.9 \%$ & $36.6 \%$ & $18.4 \%$ & $1.5 \%$ & $5.3 \%$ & $23.8 \%$ & $41.3 \%$ & $24.0 \%$ & $-5.6 \%$ \\
\hline 28 & $29.0 \%$ & $25.8 \%$ & $25.6 \%$ & $17.9 \%$ & $-1.7 \%$ & $11.6 \%$ & $35.5 \%$ & $36.8 \%$ & $17.8 \%$ & $1.7 \%$ & $5.3 \%$ & $24.2 \%$ & $41.4 \%$ & $23.3 \%$ & $-5.8 \%$ \\
\hline 29 & $29.6 \%$ & $26.1 \%$ & $25.7 \%$ & $17.5 \%$ & $-1.1 \%$ & $11.7 \%$ & $36.2 \%$ & $37.0 \%$ & $17.2 \%$ & $2.1 \%$ & $5.3 \%$ & $24.5 \%$ & $41.6 \%$ & $22.8 \%$ & $-5.8 \%$ \\
\hline 30 & $30.1 \%$ & $26.5 \%$ & $25.8 \%$ & $17.2 \%$ & $-0.4 \%$ & $11.8 \%$ & $36.9 \%$ & $37.3 \%$ & $16.8 \%$ & $2.8 \%$ & $5.4 \%$ & $24.9 \%$ & $41.9 \%$ & $22.3 \%$ & $-5.5 \%$ \\
\hline
\end{tabular}




\section{Appendix B (Cont.)}

Yellow-poplar

\begin{tabular}{|c|c|c|c|c|c|c|c|c|c|c|c|c|c|c|c|}
\hline \multirow[b]{2}{*}{ DBH } & \multicolumn{5}{|c|}{ Tree Grade 1} & \multicolumn{5}{|c|}{ Tree Grade 2} & \multicolumn{5}{|c|}{ Tree Grade 3} \\
\hline & FAS & $\# 1 C$ & $\# 2 A$ & \#3A & Over/Under & FAS & $\# 1 C$ & $\# 2 A$ & \#3A & Over/Under & FAS & $\# 1 C$ & $\# 2 A$ & \#3A & Over/Under \\
\hline 12 & $1.4 \%$ & $5.0 \%$ & $58.2 \%$ & $16.2 \%$ & $-19.2 \%$ & $0.0 \%$ & $1.0 \%$ & $54.4 \%$ & $10.0 \%$ & $-34.6 \%$ & $0.0 \%$ & $0.0 \%$ & $34.5 \%$ & $26.6 \%$ & $-38.9 \%$ \\
\hline 13 & $3.1 \%$ & $10.0 \%$ & $49.8 \%$ & $15.8 \%$ & $-21.3 \%$ & $0.0 \%$ & $1.6 \%$ & $61.3 \%$ & $10.2 \%$ & $-26.9 \%$ & $0.0 \%$ & $1.2 \%$ & $34.5 \%$ & $25.7 \%$ & $-38.6 \%$ \\
\hline 14 & $3.7 \%$ & $17.5 \%$ & $43.9 \%$ & $15.7 \%$ & $-19.2 \%$ & $3.0 \%$ & $5.8 \%$ & $51.9 \%$ & $10.7 \%$ & $-28.6 \%$ & $0.9 \%$ & $5.7 \%$ & $32.4 \%$ & $25.1 \%$ & $-35.9 \%$ \\
\hline 15 & $4.2 \%$ & $18.1 \%$ & $39.6 \%$ & $15.1 \%$ & $-23.0 \%$ & $3.6 \%$ & $14.6 \%$ & $44.8 \%$ & $11.1 \%$ & $-25.9 \%$ & $1.0 \%$ & $9.5 \%$ & $36.1 \%$ & $14.6 \%$ & $-38.8 \%$ \\
\hline 16 & $4.7 \%$ & $27.1 \%$ & $38.1 \%$ & $14.2 \%$ & $-15.9 \%$ & $4.2 \%$ & $22.1 \%$ & $39.2 \%$ & $11.4 \%$ & $-23.1 \%$ & $1.0 \%$ & $14.4 \%$ & $39.5 \%$ & $14.2 \%$ & $-30.9 \%$ \\
\hline 17 & $4.9 \%$ & $33.3 \%$ & $37.5 \%$ & $14.0 \%$ & $-10.3 \%$ & $4.4 \%$ & $27.2 \%$ & $33.1 \%$ & $11.6 \%$ & $-23.7 \%$ & $1.0 \%$ & $17.7 \%$ & $35.5 \%$ & $13.8 \%$ & $-32.0 \%$ \\
\hline 18 & $5.1 \%$ & $38.4 \%$ & $37.3 \%$ & $9.7 \%$ & $-9.5 \%$ & $4.6 \%$ & $31.5 \%$ & $28.5 \%$ & $11.8 \%$ & $-23.6 \%$ & $1.0 \%$ & $20.5 \%$ & $31.7 \%$ & $13.4 \%$ & $-33.4 \%$ \\
\hline 19 & $5.9 \%$ & $42.9 \%$ & $37.4 \%$ & $4.7 \%$ & $-9.1 \%$ & $4.9 \%$ & $35.2 \%$ & $24.8 \%$ & $12.0 \%$ & $-23.1 \%$ & $1.1 \%$ & $22.9 \%$ & $32.9 \%$ & $13.2 \%$ & $-29.9 \%$ \\
\hline 20 & $6.9 \%$ & $46.9 \%$ & $37.6 \%$ & $3.4 \%$ & $-5.2 \%$ & $5.1 \%$ & $38.5 \%$ & $21.9 \%$ & $12.1 \%$ & $-22.4 \%$ & $1.1 \%$ & $25.0 \%$ & $34.2 \%$ & $13.0 \%$ & $-26.7 \%$ \\
\hline 21 & $7.9 \%$ & $50.5 \%$ & $38.0 \%$ & $3.0 \%$ & $-0.6 \%$ & $5.3 \%$ & $41.5 \%$ & $19.5 \%$ & $12.3 \%$ & $-21.4 \%$ & $1.1 \%$ & $27.0 \%$ & $35.5 \%$ & $12.8 \%$ & $-23.6 \%$ \\
\hline 22 & $8.7 \%$ & $53.9 \%$ & $38.5 \%$ & $2.6 \%$ & $3.7 \%$ & $5.5 \%$ & $44.4 \%$ & $17.4 \%$ & $12.4 \%$ & $-20.3 \%$ & $1.1 \%$ & $28.9 \%$ & $36.8 \%$ & $12.7 \%$ & $-20.5 \%$ \\
\hline 23 & $9.3 \%$ & $56.4 \%$ & $38.6 \%$ & $2.4 \%$ & $6.7 \%$ & $5.6 \%$ & $46.4 \%$ & $15.5 \%$ & $12.5 \%$ & $-20.0 \%$ & $1.1 \%$ & $30.2 \%$ & $37.5 \%$ & $12.6 \%$ & $-18.6 \%$ \\
\hline 24 & $9.9 \%$ & $58.8 \%$ & $38.8 \%$ & $2.1 \%$ & $9.6 \%$ & $5.7 \%$ & $48.4 \%$ & $13.9 \%$ & $12.6 \%$ & $-19.4 \%$ & $1.1 \%$ & $31.5 \%$ & $38.3 \%$ & $12.5 \%$ & $-16.6 \%$ \\
\hline 25 & $10.4 \%$ & $60.4 \%$ & $38.7 \%$ & $2.2 \%$ & $11.7 \%$ & $5.8 \%$ & $49.8 \%$ & $12.3 \%$ & $12.6 \%$ & $-19.5 \%$ & $1.1 \%$ & $32.4 \%$ & $38.6 \%$ & $12.3 \%$ & $-15.6 \%$ \\
\hline 26 & $10.8 \%$ & $62.1 \%$ & $38.8 \%$ & $2.4 \%$ & $14.1 \%$ & $5.9 \%$ & $51.1 \%$ & $11.0 \%$ & $12.7 \%$ & $-19.3 \%$ & $1.1 \%$ & $33.2 \%$ & $39.1 \%$ & $12.3 \%$ & $-14.3 \%$ \\
\hline 27 & $11.1 \%$ & $63.1 \%$ & $38.5 \%$ & $2.5 \%$ & $15.2 \%$ & $5.9 \%$ & $52.0 \%$ & $9.9 \%$ & $12.7 \%$ & $-19.5 \%$ & $1.1 \%$ & $33.8 \%$ & $39.2 \%$ & $12.2 \%$ & $-13.7 \%$ \\
\hline 28 & $11.4 \%$ & $64.2 \%$ & $38.5 \%$ & $2.6 \%$ & $16.7 \%$ & $6.0 \%$ & $52.9 \%$ & $9.0 \%$ & $12.8 \%$ & $-19.3 \%$ & $1.1 \%$ & $34.4 \%$ & $39.4 \%$ & $12.1 \%$ & $-13.0 \%$ \\
\hline 29 & $11.7 \%$ & $65.4 \%$ & $38.5 \%$ & $2.7 \%$ & $18.3 \%$ & $6.0 \%$ & $53.9 \%$ & $8.2 \%$ & $12.8 \%$ & $-19.1 \%$ & $1.1 \%$ & $35.0 \%$ & $39.7 \%$ & $12.0 \%$ & $-12.2 \%$ \\
\hline 30 & $12.0 \%$ & $66.6 \%$ & $38.6 \%$ & $2.8 \%$ & $20.0 \%$ & $6.1 \%$ & $54.9 \%$ & $7.5 \%$ & $12.9 \%$ & $-18.6 \%$ & $1.1 \%$ & $35.7 \%$ & $40.1 \%$ & $12.0 \%$ & $-11.1 \%$ \\
\hline
\end{tabular}


Appendix C. The following is a list of the species in the regeneration cohort by shade tolerance group. The species composition included total of 32 species, with 15 of them classified as commercial. Shade tolerance was classified using descriptions from Burns and Honkala (1990).

COMMERCIAL SPECIES

\section{Shade-intolerant}

\section{Scientific}

Betula spp.

Liriodendron tulipfera

Prunus serotina

Quercus coccinea

\section{Mid-tolerant}

\section{Scientific}

Carya spp.

Magnolia acuminata

Quercus alba

Quercus montana

Quercus rubra

Quercus velutina

\section{Shade-tolerant}

\section{Scientific}

Acer rubrum

Acer saccharum

Fagus grandifolia

Fraxinus spp.

Tilia americana

\section{Common}

Birch

Yellow-poplar

Black Cherry

Scarlet Oak

\section{Common}

Hickory

Cucumbertree

White Oak

Chestnut Oak

Northern Red Oak

Black Oak

\section{Common}

Red Maple

Sugar Maple

American Beech

Ash

Basswood 


\title{
Appendix C (cont.)
}

\author{
OTHER SPECIES
}

\section{Shade-intolerant}

Scientific

Ailanthus altissima

Amelanchier arborea

Rhus glabra

Sassafras albidum

\section{Mid-tolerant}

\section{Scientific}

Aralia spinosa

Asimina triloba

Catalpa spp.

Platanus occidentalis

\section{Shade-tolerant}

\section{Scientific}

Carpinus caroliniana Castanea dentata

Cercis canadensis

Cornus spp.

Hamamelis virginiana

Lindera benzoin

Nyssa sylvatica

Ostrya virginiana

Tsuga canadensis

\section{Common}

Ailanthus

Serviceberry

Sumac

Sassafras

\section{Common}

Devil's Walking Stick

Pawpaw

Catalpa

Amercian Sycamore

\section{Common}

Musclewood

American Chestnut

Red Bud

Dogwood

Witch-hazel

Spice Bush

Blackgum

Hophorn Beam

Eastern Hemlock 